\title{
Marine biodiversity of an Eastern Tropical Pacific oceanic island, Isla del Coco, Costa Rica
}

\author{
Jorge Cortés ${ }^{1,2}$ \\ 1. Centro de Investigación en Ciencias del Mar y Limnología (CIMAR), Ciudad de la Investigación, Universidad de \\ Costa Rica, San Pedro, 11501-2060 San José, Costa Rica; jorge.cortes@ucr.ac.cr \\ 2. Escuela de Biología, Universidad de Costa Rica, San Pedro, 11501-2060 San José, Costa Rica
}

Received 05-I-2012. C Corrected 01-VIII-2012. Accepted 24-IX-2012.

\begin{abstract}
Isla del Coco (also known as Cocos Island) is an oceanic island in the Eastern Tropical Pacific; it is part of the largest national park of Costa Rica and a UNESCO World Heritage Site. The island has been visited since the $16^{\text {th }}$ Century due to its abundance of freshwater and wood. Marine biodiversity studies of the island started in the late $19^{\text {th }}$ Century, with an intense period of research in the 1930 's, and again from the mid 1990 's to the present. The information is scattered and, in some cases, in old publications that are difficult to access. Here I have compiled published records of the marine organisms of the island. At least 1688 species are recorded, with the gastropods (383 species), bony fishes (354 spp.) and crustaceans (at least $263 \mathrm{spp}$.) being the most species-rich groups; 45 species are endemic to Isla del Coco National Park (2.7\% of the total). The number of species per kilometer of coastline and by square kilometer of seabed shallower than $200 \mathrm{~m}$ deep are the highest recorded in the Eastern Tropical Pacific. Although the marine biodiversity of Isla del Coco is relatively well known, there are regions that need more exploration, for example, the south side, the pelagic environments, and deeper waters. Also, several groups of organisms, such as the flatworms, nematodes, nemerteans, and gelatinous zooplankton, have been observed around the Island but have been poorly studied or not at all. Citation: Cortés, J. 2012. Marine biodiversity of an Eastern Tropical Pacific oceanic island, Isla del Coco, Costa Rica. Rev. Biol. Trop. 60 (Suppl. 3): 131-185. Epub 2012 Dec 01.
\end{abstract}

Key words: Marine biodiversity, Costa Rica, Isla del Coco, Cocos Island, Eastern Pacific, endemic species.

Isla del Coco (Cocos Island) is an oceanic island in the Eastern Tropical Pacific Ocean, about $500 \mathrm{~km}$ from mainland Costa Rica (Cortés 2008), and biogeographically it is part of the Ocean Island Province (sensu Robertson \& Cramer 2009). It is a highly diverse area with the highest number of endemic species in Costa Rica (Cortés \& Wehrtmann 2009, Cortés 2013a). It was declared a National Park in 1978, a UNESCO World Heritage Site in 1997, and a Ramsar site in 1998. It is important for Costa Rica, due to of its biological and historical richness and also because the Territorial Sea surrounding the island makes the marine area of Costa Rica more than 10 times its terrestrial area (Cortés \& Wehrtmann 2009, Cortés 2013b).

Marine biodiversity studies at Isla del Coco started in the late 19th Century with the expedition of the US Fisheries Commission Steamer Albatross (see a history of marine research at what is now Parque Nacional Isla del Coco (Isla del Coco National Park) in Cortés 2008). Since then, many studies have been done but there is still more to be discovered. Hertlein (1963) compiled what was known about marine species of the Island. In this paper I update the list of marine organisms of Isla del Coco National Park, compare it with the species from the mainland, and identify areas for future research.

\section{MATERIALS AND METHODS}

Published records of marine species of Parque Nacional Isla del Coco (PNIC) were searched and species lists compiled. An 
important source was the book "Marine Biodiversity of Costa Rica, Central America" edited by Wehrtmann and Cortés (2009). Here I included overlooked and newly published records. The number of species from PNIC is compared to the numbers from the rest of the Pacific of Costa Rica. Including the mainland, the Coco Volcanic Cordillera, the pelagic areas, and the Costa Rica Thermal Dome.

The perimeter of Isla del Coco is $28.8 \mathrm{~km}$, and it is surrounded by a platform that drops off at around $180-200 \mathrm{~m}$. The perimeter at $100 \mathrm{~m}$ is $54.4 \mathrm{~km}$ and at $200 \mathrm{~m}$ is $71.4 \mathrm{~km}$. The area less than $50 \mathrm{~m}$ deep around the island is $91.5 \mathrm{~km}^{2}$, less than $100 \mathrm{~m}$ is $133 \mathrm{~km}^{2}$, and less than $200 \mathrm{~m}$ deep is $318 \mathrm{~km}^{2}$ (O.G. Lizano, pers. comm. 2011). The Linear Biodiversity Index (LBI) and the Area Biodiversity Index (ABI) were calculated as in Wehrtmann et al. (2009). To calculate the LBI, the number of species was divided by the perimeter of the island. The ABI was calculated by dividing the number of species by the area down to the $200 \mathrm{~m}$ isobaths; the depth within which almost all the species had been recorded.

\section{MARINE BIODIVERSITY OF ISLA DEL COCO NATIONAL PARK}

At least 1688 species of marine organisms (Appendix 1) have been reported from Isla del Coco National Park (PNIC). The most speciesrich groups are the gastropods (383 species), bony fishes (354 spp.) and crustaceans (at least 263 spp.) (Table 1). Close to 4,700 species of marine organisms have been reported for Costa

TABLE 1

Number of marine species reported from Isla del Coco National Park (Complete list of species in Appendix 1), from Pacific Costa Rica, species found only at PNIC, and the percentage those species exclusively

of PNIC represent within each taxa

\begin{tabular}{|c|c|c|c|c|c|}
\hline TAXA & $\begin{array}{l}\text { Species } \\
\text { from } \\
\text { PNIC }\end{array}$ & $\begin{array}{c}\text { Species from } \\
\text { Pacific } \\
\text { Costa Rica }\end{array}$ & $\begin{array}{c}\text { Species } \\
\text { found } \\
\text { only at PNIC }\end{array}$ & $\begin{array}{c}\% \text { species } \\
\text { only } \\
\text { at PNIC }\end{array}$ & References \\
\hline Virus & $2+$ & n.k. & n.k. & n.k. & 185 \\
\hline Bacteria and Archaea & $1+$ & Several & n.k. & n.k. & 82,153 \\
\hline Cyanobacteria & 1 & 28 & 1 & 3.6 & $13,181,185$ \\
\hline Dinoflagelados & 7 & 102 & 6 & 5.9 & 180,181 \\
\hline Chlorophyta & 12 & 44 & 6 & 13.6 & $13,14,74,75,76$ \\
\hline Ochrophyta & 6 & 26 & 0 & 0 & $13,14,74,76$ \\
\hline Rhodophyta & 13 & 146 & 1 & 0.7 & $13,14,74,76$ \\
\hline Foraminifera & 20 & 95 & 19 & 20.0 & $49,54,55,56,57,98,111$ \\
\hline Porifera & 8 & 62 & 8 & 12.9 & $50,68,141,186$ \\
\hline Cnidaria & 83 & 223 & 51 & 22.9 & \\
\hline Anthozoa & 48 & 87 & 28 & 32.2 & $\begin{array}{l}2,20,21,22,23,23 a, 36,44,45,46,48,72, \\
112\end{array}$ \\
\hline Scyphozoa & 7 & 10 & 4 & 40.0 & $15,16,149$ \\
\hline Hydrozoa & 28 & 127 & 19 & 15.0 & $17,37,44,80,81,98,109,130,147,148,149$ \\
\hline Mollusca & 490 & 1260 & 235 & 18.6 & \\
\hline Polyplacophora & 8 & 24 & 5 & 20.8 & $60,78,156$ \\
\hline Gastropoda & 383 & 826 & 195 & 23.6 & $\begin{array}{l}38,59,60,69,70,98,100,101,107,108 \\
114,125,130,137,150,152,172\end{array}$ \\
\hline Bivalvia & 78 & 390 & 28 & 7.2 & $69,70,89,98,118,182$ \\
\hline Cephalopoda & 21 & 20 & 7 & 35.0 & $98,99,102,144,145,146$ \\
\hline Sipuncula & 11 & 19 & 4 & 21.0 & $58,65,174$ \\
\hline Echiura & 1 & 1 & 0 & 0 & 64,65 \\
\hline Annelida & 120 & 413 & 101 & 24.5 & $\begin{array}{l}8,63,64,67,92,93,94,98,103,106,170 \\
171\end{array}$ \\
\hline
\end{tabular}


TABLE 1 (Continued)

Number of marine species reported from Isla del Coco National Park (Complete list of species in Appendix 1), from Pacific Costa Rica, species found only at PNIC, and the percentage those species exclusively

of PNIC represent within each taxa

\begin{tabular}{|c|c|c|c|c|c|}
\hline TAXA & $\begin{array}{l}\text { Species } \\
\text { from } \\
\text { PNIC }\end{array}$ & $\begin{array}{c}\text { Species from } \\
\text { Pacific } \\
\text { Costa Rica }\end{array}$ & $\begin{array}{c}\text { Species } \\
\text { found } \\
\text { only at PNIC }\end{array}$ & $\begin{array}{c}\% \text { species } \\
\text { only } \\
\text { at PNIC }\end{array}$ & References \\
\hline Crustacea & $263+$ & $888+$ & 81 & 9.1 & \\
\hline Stomatopoda & 6 & 29 & 2 & 6.9 & $176,177,179$ \\
\hline Euphausiacea & $\begin{array}{l}\text { Several } \\
\text { spp. }\end{array}$ & $20+$ & n.k. & n.k. & 39,130 \\
\hline Decapoda & 139 & 458 & 49 & 10.6 & $\begin{array}{l}1,53,73,85,88,90,91,124,136,169,177 \\
178,179,183,184\end{array}$ \\
\hline Isopoda & 3 & 37 & 2 & 5.4 & $18,25,26$ \\
\hline Mysida & $\begin{array}{l}\text { Several } \\
\text { spp. }\end{array}$ & $5+$ & n.k. & n.k. & 130,139 \\
\hline Tanaidacea & 1 & 6 & 1 & 16.7 & 96 \\
\hline Amphipoda & 25 & 117 & 11 & 9.4 & $11,79,86,87,130,157,164$ \\
\hline Cirripedia & 14 & 40 & 4 & 10.0 & 173,188 \\
\hline Copepoda & 70 & 172 & 9 & 5.3 & $130,131,165,166,167$ \\
\hline Branchiopoda & 1 & 1 & 1 & 100 & 130 \\
\hline Ostracoda & 2 & 2 & 2 & 100 & 130 \\
\hline Pycnogonida & 2 & 10 & 2 & 20.0 & 9 \\
\hline Insecta & 1 & 9 & 0 & 0 & 162 \\
\hline Chaetognatha & 8 & 27 & 6 & 22.2 & $41,130,168$ \\
\hline Bryozoa & 31 & 61 & 22 & 36.1 & $51,98,133,134,135$ \\
\hline Brachiopoda & 6 & 8 & 6 & 75.0 & $59,60,71,98$ \\
\hline Phoronida & 1 & 1 & 1 & 100 & 66 \\
\hline Echinodermata & 123 & 183 & 78 & 42.6 & \\
\hline Crinoidea & 2 & 2 & 2 & 100 & 5,7 \\
\hline Asteroidea & 30 & 36 & 24 & 66.7 & $5,7,117,119,159$ \\
\hline Ophiuroidea & 30 & 54 & 17 & 31.5 & $5,6,7,159$ \\
\hline Echinoidea & 31 & 44 & 16 & 36.4 & $5,6,7,42,43,113,159$ \\
\hline Holothuroidea & 30 & 47 & 19 & 40.4 & $5,6,7,110,159$ \\
\hline Chordata & 478 & 1083 & 119 & 11.0 & \\
\hline Appendicularia & 9 & 10 & 7 & 70.0 & $10,40,41,130$ \\
\hline Thaliacea & 3 & 4 & 3 & 75.0 & 130 \\
\hline Leptocardii & 1 & 2 & 1 & 50.0 & 158,175 \\
\hline Elasmobranchii & 35 & 84 & 16 & 19.0 & $3,34,35,47,52,115,116,122,142,143,163$ \\
\hline Actinopterygii & 354 & 858 & 84 & 9.8 & $\begin{array}{l}3,4,19,27,28,29,30,31,32,33,34,35 \\
47,62,77,83,84,95,97,104,105,121,122, \\
123,126,127,132,138,140,142,143,151, \\
155,163\end{array}$ \\
\hline Reptilia & 5 & 5 & 0 & 0 & $84,154,161$ \\
\hline Aves & 55 & 92 & 16 & 17.4 & $12,128,187$ \\
\hline Mammalia & 16 & 28 & 6 & 21.4 & 120,129 \\
\hline TOTAL & 1688 & 4690 & 747 & $15.9 \%$ & \\
\hline
\end{tabular}

Pacific Costa Rica = mainland coast $(\mathrm{MC})$, Coco Volcanic Cordillera (CVC) (also known as Cocos Ridge), Costa Rica Thermal Dome (CRTD), and Isla del Coco National Park (PNIC). + = more species than the number indicated are known, but have not been described. n.k. = not known. 
Rica (Table 1); of these species, 747 or $\sim 16 \%$ have been only reported from PNIC but not from other areas of Costa Rica. The percentages by taxonomic group ranged from 0 to $100 \%$. All brown algae, echiuran, marine insects, and reptiles from PNIC are also found in the rest of Costa Rica. While all reported branchiopods, ostracods, phoronids, and crinoids, represented by one or two species, known from Costa Rica are reported from PNIC. Some groups have a disproportionate percentage of known species at PNIC, scyphozoans (40\%), echinoderms as a phylum (42.6\%), and its classes, asteroids $(66.7 \%)$ echinoids $(36.4 \%)$ and holothurians (40.4\%), brachiopods $(75.0 \%)$, and within the chordates, cephalochordates $(50 \%)$ appendicularians $(70 \%)$ and thaliacians $(75 \%)$.

Species of several groups have been reported from other areas of Costa Rica than PNIC (Table 2). Some of these taxa we know are absent from PNIC, for example the seagrasses and mangroves, and some of the species associated to this ecosystems. Other groups have been observed, photographed or collected but there are no published accounts of them. Within these groups we have nematodes, nemerteans, ascideans, and parasites of fishes and turtles. Free-living flat worms have been observed along the mainland coast of Costa Rica as well as at PNIC, but there are no publications. Of other taxa we do not know if they are present or not, for example, marine fungi, cumaceans and kinorhynchans (Table 2). Plus there must be other marine groups that have been reported from the Eastern Tropical Pacific, for example, loriciferans (Heiner \& Neuhaus 2007) that might be present at PNIC.

Forty five species or $2.7 \%$ of the species known from PNIC are endemic (Tables 3, 4 ), and this represents $47.4 \%$ of all endemic marine species of Costa Rica (95 spp.). The number of endemic species is relatively low, but that is common in marine environments. The list of endemic marine species is presented in Table 3, as well as the reference to the publication where the species was described. Between 1893 and 1971, 16 species were described, while 29 were described from 1981 to 2011. Most endemic species are fishes (33.3\% of all endemics from PNIC) and most were described in the last 30 years (11 of the 15 species). Crustacea is the next group with most endemism, $28.9 \%$, followed by the mollusks, $15.5 \%$, all very well studied groups (Table 4 ). Within a particular group, the brachiopods have the highest percentage of endemism, $16.7 \%$ followed by the sponges and polyplacophorans with $12.5 \%$ (Table 4 ).

Biodiversity indices used to compare species diversity at Isla del Coco with that at the Costa Rican coast revealed significantly higher values at PNIC than at the coast. For example,

TABLE 2

Taxa reported from Pacific mainland Costa Rica, or Coco Volcanic Cordillera, but not from Isla del Coco National Park.

\begin{tabular}{lcc}
$\quad$ Taxonomic group & $\begin{array}{c}\text { Number of } \\
\text { species reported }\end{array}$ & $\begin{array}{c}\text { Isla del } \\
\text { Coco }\end{array}$ \\
Marine fungi (Ulken et al. 1990, Cortés 2009d) & 5 genera & n.k. \\
Seagrasses (Cortés \& Salas 2009) & 2 & Absent \\
Mangroves (Silva-Benavides 2009) & 8 & Absent \\
Nematods (De la Cruz \& Vargas 1986, Vargas 1988a, b) & Several species & Present \\
Nemerteans (Dexter 1974) & Several species & Present \\
Cumaceans (Petrescu et al. 2009) & 13 & n.k. \\
Kinorhynchans (Neuhaus 2004, Neuhaus \& Blasche 2006, Cortés 2009d) & 2 & n.k. \\
Ascidians (Van Name 1945, Tokioka 1971, 1972, Cortés 2009d, Nova-Bustos et al. 2010) & 14 & Present \\
Fish parasites (Cortés 2009e) & 46 & Present \\
Turtle parasites (Santoro \& Mattiucci 2009) & 34 & Present \\
\hline
\end{tabular}

n.k. $=$ not known; Present $=$ have been observed or collected but there are no publications. 
TABLE 3

Endemic marine species of Isla del Coco National Park, Costa Rica

\section{Phylum Porifera}

Class Hexactinellida, Order Hexactinosida, Family Tretodictyidae

1) Tretodictyum cocosensis Reiswig, 2010

\section{Phylum Cnidaria}

Class Anthozoa, Order Alcyonacea, Family Gorgoniidae

2) Leptogorgia tricorata Breedy \& Cortés, 2011

3) Pacifigorgia curta Breedy \& Guzman, 2003

Class Anthozoa, Order Scleractinia, Family Caryophylliidae

4) Anomocora carinata Cairns, 1991a

Class Hydrozoa, Order Filifora, Family Stylasteridae

5) Pliobothrus fistulosus Cairns, $1991 \mathrm{~b}$

6) Stylaster cocosensis Cairns, 1991b

\section{Phylum Mollusca}

Class Polyplacophora, Order Chitonida, Family Ischnochitonidae

7) Ischnochiton victoriae Ferreira, 1987

Class Gastropoda, Order Neogastropoda, Family Cystiscidae

8) Gibberula achenea Roth \& Coan, 1971

Class Gastropoda, Subclass Vetigastropoda, Family Haliotidae

9) Haliotis dalli roberti McLean, 1970

Class Gastropoda, Subclass Patellogastropoda, Family Lottidae

10) Lottia rothi (Lindberg \& McLean, 1981)

Class Gastropoda, Order Neogastropoda, Family Muricidae

11) Favartia shaskyi D’Attilio \& Myers, 1988

Class Gastropoda, Order Neogastropoda, Family Olividae

12) Oliva spicata deynzerae Petuch \& Sargent, 1986

Class Bivalvia, Order Ostreoida, Family Pectinidae

13) Leopecten cocosensis Waller, 2007

\section{Phylum Arthropoda}

Subphylum Crustacea, Class Malacostraca, Order Decapoda, Family Diogenidae

14) Allodardanus rugosus Haig \& Provenzano, 1965

15) Cancellus tanneri Faxon, 1893

16) Paguristes fecundus Faxon, 1893

Subphylum Crustacea, Class Malacostraca, Order Decapoda, Family Gecarcinidae

17) Johngarthi cocoensis Perger, Vargas \& Wall, 2011

Subphylum Crustacea, Class Malacostraca, Order Decapoda, Family Paguridae

18) Enallopaguropsis janetae McLaughlin, 1982

Subphylum Crustacea, Class Malacostraca, Order Decapoda, Family Palaemonidae

19) Macrobrachium cocoensis Abele \& Kim, 1984

Subphylum Crustacea, Class Malacostraca, Order Decapoda, Family Pinnotheridae

20) Parapinnixa cortesi Thoma, Heard \& Vargas, 2005

Subphylum Crustacea, Class Malacostraca, Order Decapoda, Family Porcellanidae

21) Petrolisthes cocoensis Haig, 1960

Subphylum Crustacea, Class Malacostraca, Order Decapoda, Family Upogebiidae

22) Pomatogebia cocosia (Williams, 1986)

Subphylum Crustacea, Class Malacostraca, Order Amphipoda, Family Isaeidae

23) Gammaropsis dubia (Shoemaker, 1942)

Subphylum Crustacea, Class Malacostraca, Order Amphipoda, Family Talitridae

24) Talorchestia fritzi Stebbing, 1903

Subphylum Crustacea, Class Maxillopoda, Order Monstrilloida, Family Monstrillidae

25) Cymbasoma cocoense Suárez-Morales \& Morales-Ramírez, 2009

26) Monstrillopsis chathamensis Suárez-Morales \& Morales-Ramírez, 2009

Phylum Brachiopoda

Class Rhynchonellata, Order Rhynchonellida, Family Frieleiidae

27) Hispanirhynchia? craneana (Dall, 1895) 
TABLE 3 (Continued)

Endemic marine species of Isla del Coco National Park, Costa Rica

\section{Phylum Echinodermata}

Class Asteroidea, Order Paxillosida, Family Astropectinidae

28) Astropecten benthophilus Ludwig, 1905

29) Persephonaster armiger Ludwig, 1905

Class Echinoidea, Order Clypeasteroida, Family Mellitidae

30) Encope cocosi Clark, 1948

\section{Phylum Chordata}

Subphylum Vertebrata, Class Actinopterygii, Order Gobiesociformes, Familia Gobiesocidae

31) Gobiesox woodsi (Schultz, 1944)

32) Tomicodon vermiculatus Briggs, 1955

Subphylum Vertebrata, Class Actinopterygii, Order Lophiiformes, Family Ogcocephalidae

33) Ogcocephalus porrectus Garman, 1899

Subphylum Vertebrata, Class Actinopterygii, Order Ophidiiformes, Family Bythitidae 34) Ogilbia cocoensis Møller, Schwarzhans \& Nielsen, 2005

Subphylum Vertebrata, Class Actinopterygii, Order Scorpaeniformes, Family Peristediidae

35) Peristedion nesium Bussing, 2010

Subphylum Vertebrata, Class Actinopterygii, Order Perciformes, Familia Chaenopsidae

36) Acanthemblemaria atrata Hastings \& Robertson, 1999

Subphylum Vertebrata, Class Actinopterygii, Order Perciformes, Family Dactyloscopidae

37) Gillellus chathamensis Dawson, 1977

Subphylum Vertebrata, Class Actinopterygii, Order Perciformes, Family Gobiidae

38) Chriolepis atrimelum Bussing, 1997

39) Chriolepis dialepta Bussing, 1990

40) Lythrypnus alphigena Bussing, 1990

41) Lythrypnus cobalus Bussing, 1990

42) Lythrypnus lavenbergi Bussing, 1990

43) Sicydium cocoensis (Heller \& Snodgrass, 1903)

Subphylum Vertebrata, Class Actinopterygii, Order Perciformes, Family Labridae

44) Halichoeres salmofasciatus Allen \& Robertson, 2002

Subphylum Vertebrata, Class Actinopterygii, Order Perciformes, Family Tripterygiidae

45) Axoclinus cocoensis Bussing, 1991

the Linear Biodiversity Index for Isla del Coco is 58.6, which is significantly higher than the highest value (3.8) found by Wehrtmann et al. (2009) for the Costa Rican Pacific coast. The same happens when comparing the Area Biodiversity Index of continental shelves. The value for the $200 \mathrm{~m}$ isobaths of PNIC is 5.3, compared to the highest value of 0.3 reported by Wehrtmann et al. (2009). The LBI and ABI values for the Costa Rican coastline and continental platform, respectively, were the highest when compared to other countries in the region (Wehrtmann et al. 2009). By all measures Isla del Coco is a very rich area in the eastern tropical Pacific.

\section{STATUS OF THE ENDEMIC SPECIES}

Forty five species are endemic to PNIC (Table 2). While some are abundant, such as the calcified hydrozoan Stylaster cocosensis, described in 1991 by Stephen D. Cairns, others have not been seen since they were described, for example, the sand dollar, Encope cocosi. This species had not been found alive since it was described by H.L. Clark in 1948. However, in January 2007 a specimen recently dead was dredged from deep water. In 1986 using the research submersible Johnson-SeaLink (Harbor Branch Oceanographic Institution, Fort Pierce, Florida, USA) diving to 
TABLE 4

Number of endemic marine species at Isla del Coco National Park, percentage of the total of the endemics of the island represented by a particular taxa, and percentage of endemics within its taxonomic group

\begin{tabular}{lccc}
\multicolumn{1}{c}{ TAXA } & $\begin{array}{c}\text { Number of } \\
\text { endemic species }\end{array}$ & $\begin{array}{c}\text { \% of the total } \\
\text { of endemics }\end{array}$ & $\begin{array}{c}\text { \% of endemics } \\
\text { within the group }\end{array}$ \\
Porifera & 1 & 2.2 & 12.5 \\
Cnidaria & 5 & 11.1 & 6.1 \\
Anthozoa & 3 & 6.7 & 6.4 \\
Hydrozoa & 2 & 4.4 & 7.1 \\
Mollusca & 7 & 15.5 & 1.3 \\
Polyplacophora & 1 & 2.2 & 12.5 \\
Gastropoda & 5 & 11.1 & 1.3 \\
Bivalvia & 1 & 2.2 & 1.3 \\
Crustacea & 13 & 28.9 & 4.9 \\
Decapoda & 9 & 20.0 & 6.5 \\
Amphipoda & 2 & 4.4 & 8.0 \\
Copepoda & 2 & 4.4 & 2.9 \\
Brachiopoda & 1 & 2.2 & 16.7 \\
Echinodermata & 3 & 6.7 & 2.4 \\
Asteroidea & 2 & 4.4 & 6.7 \\
Echinoidea & 1 & 2.2 & 3.2 \\
Chordata & 15 & 33.3 & 3.1 \\
Actinopterygii & 15 & 33.3 & 4.2 \\
\hline TOTAL & 45 & & 2.7 \\
\hline
\end{tabular}

several hundred meters, collected specimens that resulted in new species and some were endemic (Cairns 1991a, b). We don not know the status of some of those endemics because no submersible with the depth capacity of the Johnson-Sea-Link has been back to the island. There is now another submersible operating more regularly at the island, the DeepSee (Undersea Hunter Group, Puntarenas, Costa Rica), with a depth capability of $450 \mathrm{~m}$ (Cortés \& Blum 2008). We have been able to observed several of the deepwater endemics collected in 1986, some are relatively abundant. Eleven endemic species have been described in the last decade so it's possible that eventually they will be found in other areas. Some species of fishes which were initially classified as endemic to one of the oceanic islands of the eastern Tropical Pacific are now reported from one or more of the other oceanic islands. For example, Stegastes arcifrons which have been found in the three oceanic islands, Galápagos, Malpelo and
Isla del Coco or Serranus tico and Halichoeres discolor, found in Isla del Coco and Malpelo. Starr et al. (2012) indicated in their study of deepwater fishes of Isla del Coco National Park and Las Gemelas Seamount that probably deep areas in the eastern tropical Pacific will have similar species, but more studies and collections are needed.

\section{DISCUSSION}

Isla del Coco National Park has a rich marine biodiversity with some groups having been studied for many years and numerous scientists. For example, fishes and mollusks, especially gastropods, are relatively well known while other groups such as cyanobacteria, gelatinous zooplankton, nematodes and flatworms have been poorly studied or never at all even though we know they are on the island. As a result of recent expeditions (20062012) many new records of species have been 
reported (Dean et al. 2010a, 2012, SibajaCordero et al. 2012), including a phylum, Phoronida (Dean et al. 2010b), and new species are being discovered, even of conspicuous groups such as octocorals (Breedy \& Cortés 2011, Breedy et al. 2012). Reports of new records and descriptions of new species are being prepared at the present time.

Hertlein (1963) did a compilation of published marine species of Isla del Coco, and included a biogeographic analysis of the flora and fauna of the island, plus an annotated bibliography. He reported 334 species (Table 5), with the gastropods (62 species) as the most species-rich group, followed by bony fishes (59) and crustaceans (56). The number of species and of different taxonomic groups has increased significantly but the same pattern of the most species-rich groups is maintained. Wehrtmann et al. (2009) reported 1,142 marine species for Isla del Coco National Park, with the most species-rich groups, in the same order, being the same as above. Here, 546 more species were added to the list of marine species of Isla del Coco National Park, and more will be added in the near future as other groups, depths and areas of the island are being studied.

Hickman (2009), in his study of the marine invertebrate biota of the Galápagos Islands, found that while some groups of species are depauperated others displayed high diversity when compared to mainland Ecuador. Similar patters were observed at Isla del Coco National Park. These patterns can be attributed to several possible factors likely acting in concert, both for source populations from elsewhere as well as established populations at PNIC: variation in the dispersal potential to and from PNIC, the probability of recruitment at PNIC, and the potential for survival and continued recruitment based on local environmental conditions. Species with long-lived larvae will have a chance of dispersing more than others if they find the type of environmental conditions necessary to survive and reproduce. For example, the absence of seagrasses and the low number of species of bivalves may be due to the lack of soft sediments where they can live.

\section{AREAS FOR FUTURE RESEARCH}

The least studied area of PNIC is the south side due to the normally rough sea conditions on that side (Lizano 2008). From a few observations, several species and environments in the south are different from the north in species density and composition, probably due to the currents that flow there (Cortés \& Blum 2008).

TABLE 5

Marine species reported by Hertlein (1963) for Isla del Coco; fishes from Fowler (1938 in Hertlein 1963)

\begin{tabular}{lccc} 
& TAXA & TAmber of species & Number of species \\
Foraminifera & 17 & Cirripedia & 3 \\
Cnidaria & 24 & Copepoda & 2 \\
$\quad$ Anthozoa & 19 & Brachiopoda & 1 \\
Hydrozoa & 5 & Bryozoa & 20 \\
Mollusca & 90 & Echinodermata & 45 \\
Polyplacophora & 4 & Asteroidea & 6 \\
Gastropoda & 62 & Ophiuroidea & 15 \\
Bivalvia & 12 & Echinoidea & 13 \\
Cephalopoda & 12 & Holothuroidea & 11 \\
Annelida & 9 & Chordata & 72 \\
Crustacea & 56 & Chondrichtyes & 13 \\
Decapoda & 50 & Actinopterygii & 59 \\
Amphipoda & 1 & & \\
\hline TOTAL 334 species & & & \\
\hline
\end{tabular}


More sampling should be done on that side in the future in the shallow and deepwaters of the south for better understanding the biodiversity of PNIC, and the effect of currents on that biodiversity.

There are several groups of organisms which have been observed and in some cases collected but for which there are no publications. Examples include cyanobacteria, sponges, flatworms, and nematodes (Table 2). For a few groups, especially the best known, there are some publications on their biogeographic relationships. Several species of stomatopods (Manning 1972), most reef building corals (Cortés 1986, 2011, Glynn \& Ault 2000), some mollusks (Montoya \& Kaiser 1988), sea urchins (Lessios et al. 1998), and about one third of the shore-fishes (Robertson et al. 2004) are related western Pacific species. More molecular work is needed to discover cryptic species (e.g. Knowlton 2000, Boulay et al. in prep.), and the genetic connectivity (e.g. Lessios \& Robertson 2006) of PNIC populations with other areas.

Polidoro et al. (2012) indicated the importance of species-specific information regarding population trends and extinction risks for developing conservation strategies. To do this we must first know what is there, which this paper intends to fulfill. Then we need to know what is the status of the populations, how they are changing over time, and what is affecting them. Unfortunately for most groups this information is unknown.

\section{ACKNOWLEDGEMENTS}

I thank the following scientists for their help with their group of specialty and/or review of the manuscript: Fabián Acuña, Juan José Alvarado, Peter Auster, Gilbert Barrantes, Odalisca Breedy, Richard Brusca, William Bussing, Allan Carillo, Allen Collins, Harlan Dean, Ana Dittel, Cindy Fernández, Cristian Pacheco, Christian Emig, José Leal, Laurence Madin, Ross Robertson, Eva Salas, Astrid
Sánchez, Jeffrey Sibaja-Cordero, Rick Starr, Robert van Syos, Benjamin Victor and Rita Vargas. Omar Lizano for providing the data on perimeter and areas of the marine sections of Isla del Coco National Park (PNIC). Research at PNIC has been funded by the Vicerrectoría de Investigación and CIMAR of the Universidad de Costa Rica, Conservation International (CI), Fonds Français pour l'Environnement Mondial (FFEM) and the Consejo Nacional de Rectores de las Universidades Públicas de Costa Rica (CONARE). The preparation of this publication was advanced significantly during my stay as Visiting Professor at Newcastle University, Newcastle, United Kingdom. Support has been received from Área de Conservación Marina Isla del Coco (ACMIC) and the Undersea Hunter Group.

\section{RESUMEN}

La Isla del Coco es una isla oceánica en el Pacífico Tropical Oriental; es parte del Parque Nacional más grande de Costa Rica y es un sitio de Patrimonio Mundial. La isla ha sido visitada desde el Siglo XVI por su abundancia de agua dulce y árboles. Estudios de biodiversidad marina de la isla empezaron a finales del Siglo XIX, con un intenso período de investigación en la década de 1930, y de nuevo desde mediados de la década de 1990 al presente. La información sobre organismos marinos se encuentra dispersa y en algunos casos en publicaciones antiguas. En el presente trabajo se recopilan todos los registros publicados de organismos marinos de la isla. Al menos 1688 especies han sido registradas, con los gasterópodos (383 especies), peces óseos (354 spp.) y crustáceos (al menos 263 spp.) como los grupos con más especies; de esas, 45 son especies endémicas del Parque Nacional Isla del Coco (2.7\% del total). El número de especies por kilómetro de costa y por kilómetro cuadrado de lecho marino de menos de $200 \mathrm{~m}$ de profundidad son los más altos de cualquier sitio estudiado. Aunque se conoce relativamente bien la biodiversidad marina de la Isla del Coco, hay regiones, por ejemplo, el lado sur, los ambientes pelágicos, y las zonas más profundas que requieren de más exploración. También, varios grupos de organismos han sido observados en la isla pero muy poco estudiados o no del todo, por ejemplo los gusanos planos, nemátodos y el plancton gelatinosos.

Palabras clave: Biodiversidad marina, Costa Rica, Isla del Coco, Pacífico Oriental, especies endémicas 


\section{REFERENCES}

NOTE: Number references as used in the Tables.

1. Abele, L.G. \& W. Kim. 1984. Notes on the freshwater shrimps of Isla del Coco with description of Macrobrachium cocoense, new species. Proc. Biol. Soc. Washington 97: 951-960.

2. Acuña, F.H., J. Cortés \& A. Garese. 2012. Ocurrence of the sea anemone Telmatactis panamensis (Verrill, 1869. (Cnidaria: Anthozoa: Actiniaria. at Cocos Island National Park, Costa Rica. Rev. Biol. Trop. 60 (Suppl. 3): 201-205.

3. Allen, G.R. \& D.R. Robertson. 1994. Fishes of the Tropical Eastern Pacific. Univ. Hawaii Press, Honolulu, Hawai'i. 332 p.

4. Allen, G.R. \& D.R. Robertson. 2002. Halichoeres salmofasciatus, a new species of wrasse (Labridae) from Isla del Coco, tropical eastern Pacific. Aqua 5: 65-72.

5. Alvarado, J.J. 2010. Isla del Coco (Costa Rica) Echinoderms: State of knowledge, p. 103-113. In: L.G. Harris, S.A. Böttger, C.W. Walker \& M.P. Lesser (eds.). Echinoderms: Durham. Proc. 12th Int. Echinoderm Conf. CRC Press, Taylor \& Francis Group, Balkema, Leiden, Netherlands.

6. Alvarado, J.J. \& A. Chiriboga. 2008. Distribución y composición de los equinodermos de las aguas someras en la Isla del Coco, Costa Rica (Pacífico Oriental). Rev. Biol. Trop. 56 (Suppl. 2): 99-111.

7. Alvarado, J.J. \& J. Cortés. 2009. Echinoderms. Text: 421-433, Species list, CD: 392-408. In: I.S. Wehrtmann \& J. Cortés (Eds.). Marine Biodiversity of Costa Rica, Central America. Springer, Berlin.

8. Bakus, G.J. 1975. Marine zonation and ecology of Cocos Island, off Central America. Atoll Res. Bull.179: $1-11$.

9. Bamber, R.N. 2009. Sea-spiders. Text: 307-311, Species list, CD: 237-238. In: I.S. Wehrtmann \& J. Cortés (Eds.). Marine Biodiversity of Costa Rica, Central America. Springer, Berlin.

10. Barham, E.G. 1979. Giant larvacean houses: observations from deep submersibles. Science 205: 1129-1131.

11. Barnard, J.L. 1991. Amphipoda of the Galápagos Islands. Pp. 193-206. In: M.J. James (ed.), Galápagos Marine Invertebrates: Taxonomy, Biogeography, and Evolution in Darwin's Islands. Plenum Press, New York and London.

12. Barrantes, G. \& J. Chaves-Campos. 2009. Birds in coastal and marine environments. Text 469-478, Species list, CD: 479-484. In: I.S. Wehrtmann \& J. Cortés (Eds.). Marine Biodiversity of Costa Rica, Central America. Springer, Berlin.
13. Bernecker, A. 2009. Marine benthic algae. Text 109117, Species list, CD: 17-70. In: I.S. Wehrtmann \& J. Cortés (Eds.). Marine Biodiversity of Costa Rica, Central America. Springer, Berlin.

14. Bernecker, A. \& I.S. Wehrtmann. 2009. New records of benthic marine algae and Cyanobacteria for Costa Rica, and a comparison with other Central American countries. Helgol. Mar. Res. 63: 219-229.

15. Bigelow, H.B. 1909. Reports of the scientific results of the Expedition to the Eastern Tropical Pacific, in charge of Alexander Agassiz, by the U. S. Fish Commission Steamer "Albatross," from October, 1904, to March, 1905, Lieut. Commander L. M. Garrett, U.S.N., commanding. XVI. The Medusae. Mem. Mus. Comp. Zoöl., Harvard Coll. XXXVII: 1-243.

16. Bigelow, H.B. 1928. Scyphomedusae from the Arcturus Oceanographic Expedition. Zoologica 8: 495-524.

17. Bigelow, H.B. 1931. Siphonophorae from the Arcturus Oceanographic Expedition. Zoologica 8: 525-592.

18. Bowman, T.E. 1977. Isopod crustaceans (except Anthuridae) collected on the Presidential Cruise of 1938. Proc. Biol. Soc. Washington 89: 653-666.

19. Bradbury, M.G. 1980. A revision of the fish genus Ogcocephalus with descriptions of new species from the western Atlantic Ocean (Ogcocephalidae: Lophiformes). Proc. California Acad. Sci. 42: 229-285.

20. Breedy, O. 2009. Octocorals. Text: 161-167, Species list, CD: 108-111. In: I.S. Wehrtmann \& J. Cortés (Eds.). Marine Biodiversity of Costa Rica, Central America. Springer, Berlin.

21. Breedy, O. \& J. Cortés. 2008. Octocorals (Coelenterata: Anthozoa: Octocorallia) of Isla del Coco, Costa Rica. Rev. Biol. Trop. 56 (Suppl. 2): 71-77.

22. Breedy, O. \& J. Cortés. 2011. Morphology and taxonomy of a new species of Leptogorgia (Cnidaria: Octocorallia: Gorgoniidae) in Cocos Island National Park, Pacific Costa Rica. Proc. Biol. Soc. Washington 124: 62-69.

23. Breedy, O. \& H.M. Guzman. 2003. Octocorals from Costa Rica: The genus Pacifigorgia (Coelenterata: Octocorallia: Gorgoniidae). Zootaxa 281: 1-60.

23a. Breedy, O., L.P. Van Ofwegen \& S. Vargas. 2012. A new family of soft corals (Anthozoa, Octocorallia, Alcyonacea) from the aphotic tropical eastern Pacific waters revealed by integrative taxonomy. Syst. Biod. 10: 351-359.

24. Briggs, J.C. 1955. A monograph of the clingfishes (Order Xenopterygii). Stanford Ichthyol. Bull. 6: $1-224$.

25. Brusca, R.C. \& E.W. Iverson. 1985. A guide to the marine isopod crustacea of Pacific Costa Rica. Rev. Biol. Trop. 33 (Suppl. 1): 1-77. 
26. Brusca, R.C. \& I.S. Wehrtmann. 2009. Isopods. Text: 257-264, Species list, CD: 206-211. In: I.S. Wehrtmann \& J. Cortés (Eds.). Marine Biodiversity of Costa Rica, Central America. Springer, Berlin.

27. Bussing, W.A. 1983. A new tropical eastern Pacific labrid fish, Halichoeres discolor endemic to Isla del Coco. Rev. Biol. Trop. 31: 19-23.

28. Bussing, W.A. 1985. Los peces de la Familia Labridae de la costa Pacífica de Costa Rica. Rev. Biol. Trop. 33: 81-98.

29. Bussing, W.A. 1990. New species of gobiid fishes of the genera Lythrypnus, Elacatinus and Chriolepis. Rev. Biol. Trop. 38: 99-118.

30. Bussing, W.A. 1991. A new genus and two new species of tripterygiid fishes from Costa Rica. Rev. Biol. Trop. 39: 77-85.

31. Bussing, W.A. 1991. A new species of eastern Pacific moray eel (Pisces: Muraenidae). Rev. Biol Trop. 39: 97-102.

32. Bussing, W.A. 1997. Chriolepis atrimelum (Gobiidae) a new species of gobiid fish from Isla del Coco, Costa Rica. Rev. Biol. Trop. 45: 1547-1552.

33. Bussing, W.A. 2010. A new fish, Peristedion nesium (Scorpaeniformes: Peristediidae) from Isla del Coco, Costa Rica. Rev. Biol. Trop. 58: 1149-1156.

34. Bussing, W.A. \& M.I. López. 2005. Peces de la Isla del Coco y peces arrecifales de la costa Pacífica de América Central Meridional / Fishes of Cocos Island and Reef Fishes of the Pacific Coast of Lower Central America. Rev. Biol. Trop. 53 (Suppl. 2): 192 p.

35. Bussing, W.A. \& M.I. López. 2009. Text: 453-458, Species list, CD: 412-473. In: I.S. Wehrtmann and J. Cortés (Eds.). Marine Biodiversity of Costa Rica, Central America. Springer, Berlin.

36. Cairns, S.D. 1991a. A revision of the ahermatypic Scleractinia of the Galápagos and Cocos Islands. Smithsonian Contr. Zool. 504. 32 p.

37. Cairns, S.D. 1991b. New records of Stylasteridae (Hydrozoa: Hydroida) from the Galápagos and Cocos Islands. Proc. Biol. Soc. Washington 104: 209-228.

38. Camacho-García, Y.E. 2009. Benthic opisthobranchs. Text: 371-386, Species list, CD: 330-347. In: I.S. Wehrtmann \& J. Cortés (Eds.). Marine Biodiversity of Costa Rica, Central America. Springer, Berlin.

39. Castellanos, I., E. Suárez-Morales \& A. MoralesRamírez. 2009a. Euphausiids. Text: 199-207, Species list, CD: 164-166. In: I.S. Wehrtmann \& J. Cortés (Eds.). Marine Biodiversity of Costa Rica, Central America. Springer, Berlin.

40. Castellanos, I.A., A. Morales-Ramírez \& E. Suárez-Morales. 2009b. Appendicularians (Urochordata). Text: 445-452, Species list, CD: 411. In: I.S.
Wehrtmann \& J. Cortés (Eds.). Marine Biodiversity of Costa Rica, Central America. Springer, Berlin.

41. Castellanos-Osorio, I., R.M. Hernández-Flores, Á. Morales-Ramírez \& M. Corrales-Ugalde. 2012. Apendicularias (Urochordata) y quetognatos (Chaetognatha) del Parque Nacional Isla del Coco, Costa Rica. Rev. Biol. Trop. 60 (Suppl. 3): 243-255.

42. Clark, H.L. 1940. Eastern Pacific Expeditions of the New York Zoological Society. XXI Notes on Echinodermas from west coast of Central America. Zoologica 25: 331-352.

43. Clark, H.L. 1948. A report on the Echini of the warmer eastern Pacific, based on the collections of the Velero III. Allan Hancock Pac. Exp. 8: 225-352.

Cortés, J. 1986. Biogeografía de corales hermatípicos: el istmo centroamericano. Anales Inst. Cienc. Mar Limnol., UNAM 13: 297-304.

44. Cortés, J. 1996/1997. Biodiversidad marina de Costa Rica: Filo Cnidaria. Rev. Biol. Trop. 44(3)/45(1): 323-334.

Cortés, J. 2008. Historia de la investigación marina de la Isla del Coco, Costa Rica. Rev. Biol. Trop. 56 (Suppl. 2): $1-18$.

45. Cortés, J. 2009b. Zoanthids, actiniarians, and corallimorphs. Text: 157-159, Species list, CD: 105-107. In: I.S. Wehrtmann \& J. Cortés (Eds.). Marine Biodiversity of Costa Rica, Central America. Springer, Berlin.

46. Cortés, J. 2009c. Stony corals. Text: 169-173, Species list, CD: 112-118. In: I.S. Wehrtmann \& J. Cortés (Eds.). Marine Biodiversity of Costa Rica, Central America. Springer, Berlin.

Cortés, J. 2009d. Other taxonomic groups (Fungi, kinorhynchs, invertebrate chordates). Text: 497-500, Species list, CD: 491-492. In: I.S. Wehrtmann \& J. Cortés (Eds.). Marine Biodiversity of Costa Rica, Central America. Springer, Berlin.

Cortés, J. 2009e. Marine fish parasites. Text: 501-505, Species list, CD: 493-496. In: I.S. Wehrtmann \& J. Cortés (Eds.). Marine Biodiversity of Costa Rica, Central America. Springer, Berlin.

Cortés, J. 2011. Eastern Tropical Pacific coral reefs, Pp. 351-358. In: D. Hopley (Ed.). The Encyclopedia of Modern Coral Reefs: Structure, Form and Process. Springer, Berlín.

Cortés, J. 2013a. Cocos Island marine ecosystems. In M. Kappelle (Ed.). Costa Rican Ecosystems. The University of Chicago Press, Chicago and London. In press.

Cortés, J. 2013b. The Pacific coastal and marine ecosystems. In M. Kappelle (Ed.). Costa Rican Ecosystems. The University of Chicago Press, Chicago and London. In press. 
47. Cortés, J. \& S. Blum. 2008. Life down to $450 \mathrm{~m}$ at Isla del Coco, Costa Rica. Rev. Biol. Trop. 56 (Suppl. 2): 189-206.

48. Cortés, J. \& H.M. Guzmán. 1998. Organismos de los arrecifes coralinos de Costa Rica: Descripción, distribución geográfica e historia natural de los corales zooxantelados (Anthozoa: Scleractinia) del Pacífico. Rev. Biol. Trop. 46: 55-92.

Cortés, J. \& E. Salas. 2009. Seagrasses. Text: 119-122, Species list, CD: 71-72. In: I.S. Wehrtmann \& J. Cortés (Eds.). Marine Biodiversity of Costa Rica, Central America. Springer, Berlin.

Cortés, J. \& I.S. Wehrtmann. 2009. Diversity of marine habitats of the Caribbean and Pacific of Costa Rica. Capítulo I, Pp. 1-45. In: I.S. Wehrtmann \& J. Cortés (Eds.). Marine Biodiversity of Costa Rica, Central America. Springer, Berlin.

49. Cortés, J., C. Mora-Baumgartner \& V. Nielsen. 2009a. Foraminiferans. Text: 131-135, Species list, CD: 79-82. In: I.S. Wehrtmann \& J. Cortés (Eds.). Marine Biodiversity of Costa Rica, Central America. Springer, Berlin.

50. Cortés, J., N. Van der Hal \& R.W.M. Van Soest. 2009b. Sponges. Text: 137-142, Species list, CD 83-93. In: I.S. Wehrtmann \& J. Cortés (Eds.). Marine Biodiversity of Costa Rica, Central America. Springer, Berlin.

51. Cortés, J., V. Nielsen \& A. Herrera-Cubilla. 2009c. Bryozoans. Text: 413-416, Species list, CD: 385-388. In: I.S. Wehrtmann \& J. Cortés (Eds.). Marine Biodiversity of Costa Rica, Central America. Springer, Berlin.

52. Cortés, J., A. Sánchez-Jiménez, A. Rodríguez-Arrieta, G. Quirós-Barrantes, P.C. González \& S. Blum. 2012. Elasmobranchs observed in deep waters $(45-330 \mathrm{~m})$ at Isla del Coco National Park, Costa Rica (Eastern Tropical Pacific). Rev. Biol. Trop. 60 (Suppl. 3): 257-273.

53. Crane, J. 1975. Fiddler Crabs of the World. Ocypodidae: Genus Uca. Princeton Univ. Press, Princeton, New Jersey. 738 p.

54. Crouch, R.W. \& C.W. Poag. 1987. Benthic Foraminifera of the Panamanian Province: distribution and origins. J. Foram. Res. 17: 153-176.

55. Cushman, J.A. \& I. McCulloch. 1939. A report on some arenaceous Foraminifera. Allan Hancock Pac. Exped. 6: 1-113.

56. Cushman, J.A. \& I. McCulloch. 1942. Some Virgulininae in the Collections of the Allan Hancock Foundation. Allan Hancock Pac. Exped. 6: 179-230.

57. Cushman, J.A. \& I. McCulloch. 1950. Some Lagenidae in the collections of the Allan Hancock Foundation. Allan Hancock Pac. Exped. 6: 295-364.
58. Cutler, N., E. Cutler \& J.A. Vargas. 1992. Peanut worms (Phylum Sipuncula) from Costa Rica. Rev. Biol. Trop. 40: 153-158.

59. Dall, W.H. 1895. Scientific results of explorations by the U.S. Fish Commission Steamer Albatross. No. XXXIV. Report on Mollusca and Brachiopoda dredged in deep water, chiefly near the Hawaiian Islands, with illustrations of hitherto unfigured species from northwest America. Proc. U.S. Natl. Mus. 17(1032): 675-733.

60. Dall, W.H. 1908. Reports on the dredging operations off the west coasts of Central America to the Galapagos, to the west coast of Mexico, and in the Gulf of California, in charge of Alexander Agassiz, carried on by the U.S. Fish Commission steamer "Albatross", during 1891, Lieut. Commander Z.L. Tanner, U.S.N., commanding. XXXVII, and Reports on the scientific results of the expedition to the eastern tropical Pacific, in charge of Alexander Agassiz, by the U.S. Fish Commission steamer "Albatross," from October, 1904, to March, 1905, Lieut. Commander L.M. Garrett, U.S.N., commanding. XIV. The Mollusca and Brachiopoda. Bull. Mus. Comp. Zoöl., Harvard Coll. XLIII: 205-487.

61. D’Attilio, A. \& B.W. Myers. 1988. A new species of Favartia from the eastern Pacific (Gastropoda: Muricidae). Nautilus 102: 106-109.

62. Dawson, C.E. 1977. Studies of the eastern Pacific sand stargazers (Pisces: Dactyloscopidae). 4. Gillellus, Sindoscopus new genus, and Heteristius with description of new species. Proc. California Acad. Sci. 41: 125-160.

De la Cruz, E.M. \& J.A. Vargas. 1986. Estudio preliminar de la meiofauna de la playa fangosa de Punta Morales, Golfo de Nicoya, Costa Rica. Brenesia 25-26: 89-87.

63. Dean, H.K. 2004. Marine biodiversity of Costa Rica: Class Polychaeta (Annelida). Rev. Biol. Trop. 52 (Suppl. 2): 131-181.

64. Dean, H.K. 2009. Polychaetes and echiurans. Text: 181-191, Species list, CD: 122-159. In: I.S. Wehrtmann \& J. Cortés (Eds.). Marine Biodiversity of Costa Rica, Central America. Springer, Berlin.

65. Dean, H.K., J.A. Sibaja-Cordero, J. Cortés, R. Vargas \& G.Y. Kawauchi. 2010a. Sipunculids and Echiurans of Isla del Coco (Cocos Island), Costa Rica. Zootaxa 2557: 60-68.

66. Dean, H.K., J.A. Sibaja-Cordero \& J. Cortés. 2010 b. Occurrence of the phoronid Phoronopsis albomaculata in Cocos Island, Costa Rica. Pac. Sci. 64: 459-462.

67. Dean, H.K., J.A. Sibaja-Cordero \& J. Cortés. 2012. Polychaetes (Annelida: Polychaeta) of Parque Nacional Isla del Coco, Pacific Costa Rica. Pac. Sci. 63: 347-386. 
Dexter, D.M. 1974. Sandy-beach fauna of the Pacific and Atlantic coasts of Costa Rica and Colombia. Rev. Biol. Trop. 22: 51-66.

68. Díaz-Agras, G. 2008. Revision of the genus Pozziella (Porifera: Poecilosclerida) with description of three new species from the eastern Pacific. Zootaxa 1866: 69-94.

69. Emerson, W.K. 1994. A zoogeographic summary of the marine mollusks of Clipperton Island (Tropical Eastern Pacific Ocean). Festivus 26: 62-71.

70. Emerson, W.K. 1995. A zoogeographic summary of the marine mollusks of the Revillagigedo Islands (Tropical Eastern Pacific Ocean). Festivus 27: 3-18.

71. Emig, C.C. 2009. Brachipods. Text: 417-420, Species list, CD: 389-391. In: I.S. Wehrtmann \& J. Cortés (Eds.). Marine Biodiversity of Costa Rica, Central America. Springer, Berlin.

72. Excoffon, A.C., F.H. Acuña \& J. Cortés. 2009. The sea anemone Nemanthus californicus (Cnidaria, Actiniaria, Nemanthidae) from Costa Rica: re-description and first record outside the type locality. Mar. Biodiv. Rec. 2: 1-5.

73. Faxon, W. 1893. Reports on the dredging operations off the west coasts of Central America to the Galapagos, to the west coast of Mexico, and in the Gulf of California, in charge of Alexander Agassiz, carried on by the U.S. Fish Commission steamer "Albatross", during 1891, Lieut. Commander Z.L. Tanner, U.S.N., commanding. VI. Preliminary descriptions of new species of Crustacea. Bull. Mus. Comp. Zoöl., Harvard Coll. XXIV: 149-220.

74. Fernández, C. 2008. Flora marina del Parque Nacional Isla del Coco, Costa Rica, Pacífico Tropical Oriental. Rev. Biol. Trop. 56 (Suppl. 2): 57-69.

75. Fernández, C. \& J.J. Alvarado. 2008. Chlorophyta de la costa Pacífica de Costa Rica. Rev. Biol. Trop. 56 (Suppl. 4): 149-162.

76. Fernández-García, C., R. Riosmena-Rodríguez, B. Wysor, O.L. Tejada \& J. Cortés. 2011. Checklist of the Pacific marine macroalgae of Central America. Bot. Mar. 54: 53-73.

77. Fernández-Leiva, S. 1996. Taxonomía del ictioplancton en la Isla del Coco, Costa Rica. Thesis, Univ. Costa Rica, San Pedro, Costa Rica. 175 p.

78. Ferreira, A.J. 1987. The chiton fauna of Cocos Island, Costa Rica (Mollusca: Polyplacophora) with the description of two new species. Bull. Sci. California Acad. Sci. 86: 41-53.

79. Foster, J.M., S.E. Lecroy, R.W. Heard \& R. Vargas. 2009. Gammaridean Amphipods. Text 265-274, Species list, CD: 212-216. In: I.S. Wehrtmann \& J. Cortés (Eds.). Marine Biodiversity of Costa Rica, Central America. Springer, Berlin.
80. Fraser, C.M. 1938. Hydroids of the 1932, 1933, 1935, and 1938 Allan Hancock Pacific Expeditions. Allan Hancock Pac. Exped. 4: 129-153.

81. Fraser, C.M. 1948. Hydroids of the Allan Hancock Pacific Expeditions since March, 1938. Allan Hancock Pac. Exped. 4: 179-335.

82. Gallardo, V.A. \& C. Espinoza. 2007. New communities of large filamentous sulfur bacteria in the eastern South Pacific. Int. Microbiol. 10: 97-102.

83. Garman, S. 1899. Reports on an exploration off the west coasts of Mexico, Central and South America, and off the Galapagos Islands, in charge of Alexander Agassiz, by the U.S. Fish Commission Steamer "Albatross", during 1891, Lieut. Commander Z.L. Tanner U.S.N., commanding. XXVI. The Fishes. Mem. Mus. Comp. Zoöl., Harvard Coll. XXIV: 1-432.

84. Garrison, G. 2005. Peces de la Isla del Coco/Isla del Coco Fishes, 2nd ed. Edit. INBio, Heredia, Costa Rica. 429 p.

85. Garth, J.S. 1991. Taxonomy, distribution, and ecology of Galápagos Brachyra. Pp. 123-145. In: M.J. James (Ed.). Galápagos Marine Invertebrates: Taxonomy, Biogeography, and Evolution in Darwin's Islands. Plenum Press, New York, London.

86. Gasca, R. 2009. Hyperiid amphipods. Text: 275-282. Species list, CD: 217-218. In: I.S. Wehrtmann \& J. Cortés (Eds.). Marine Biodiversity of Costa Rica, Central America. Springer, Berlin.

87. Gasca, R. \& Á. Morales-Ramírez. 2012. Anfípodos hiperídeos (Crustacea: Peracarida) del Parque Nacional Isla del Coco, Costa Rica, Pacífico Tropical Oriental. Rev. Biol. Trop. 60 (Suppl. 3): 223-233.

Glynn, P.W. \& J. Ault. 2000. A biogeographic analysis and review of the far eastern Pacific coral reef region. Coral Reefs 19: 1-23.

88. Gore, R.H. 1982. Porcellanid crabs from the coasts of Mexico and Central America (Crustacea: Decapoda: Anomura). Smithsonian Contr. Zool. 363: 1-34.

89. Grau, G. 1959. Pectinidae of the eastern Pacific. Allan Hancock Pac. Exped. 23: 1-308.

90. Haig, J. 1960. The Porcellanidae (Crustacea: Anomura) of the eastern Pacific. Allan Hancock Pac. Exped. 24: $1-440$.

91. Haig, J. \& A.J. Provenzano. 1965. A new genus and two new species of diogenid hermit crabs (Decapoda, Anomura). Crustaceana 9: 199-207.

92. Hartman, O. 1939a. Polychaetous Annelids. Part I. Aphroditidae to Pisionidae. Allan Hancock Pac. Exped. 7: 1-155.

93. Hartman, O. 1939b. The Polychaetous Annelids collected on the Presidential Cruise of 1938. Smithsonian Miscel. Coll. 98(13): 1-22. 
94. Hartman, O. 1940. Polychaetous Annelids. Part II. Chrysopetalidae to Goniadidae. Allan Hancock Pac. Exped. 7: 173-287

95. Hastings, P.A. \& D.R. Robertson 1999. Acanthemblemaria atrata and Acanthemblemaria mangognatha, new species of eastern Pacific barnacle blennies (Chaenopsidae) from Isla del Coco, Costa Rica, and Islas Revillagigedo, Mexico, and their relationships with other barnacle blennies. Rev. Francaise Aquariol. Herpetol. 25: 107-118.

96. Heard, R.W., O. Breedy \& R. Vargas. 2009. Tanaidaceans. Text: 245-256, Species list, CD: 204-205. In: I.S. Wehrtmann \& J. Cortés (Eds.). Marine Biodiversity of Costa Rica, Central America. Springer, Berlin.

97. Heller, E. \& R.E. Snodgrass. 1903. Papers from the Hopkins-Stanford Galapagos Expedition 1898-1899. XV. New fishes. Proc. Washington Acad. Sci. 5: 189-229.

98. Hertlein, L.G. 1963. Contribution to the biogeography of Cocos Island, including a bibliography. Proc. California Acad. Sci. $4^{\text {th }}$ Ser. 32: 219-289.

Heiner, I. \& B. Neuhaus. 2007. Loricifera from the deep sea at the Galápagos Spreading Center, with a description of Spinoloricus turbatio gen. et sp. nov. (Nanaloricidae). Helgol. Mar. Res. 61: 167-182.

Hickman, C.P., Jr. 2009. Evolutionary responses of marine invertebrates to insular isolation in Galapagos. Galápagos Res. 66: 32-42.

99. Hochberg, F.G. \& Y.E. Camacho-García. 2009. Squids and octopuses. Text: 399-407, Species list, CD: 379382. In: I.S. Wehrtmann \& J. Cortés (Eds.). Marine Biodiversity of Costa Rica, Central America. Springer, Berlin

100. Hollmann, M. 1996. Polinices (Mammilla) simiae on Isla del Coco, Costa Rica: another Indo-Pacific invader into the Panamic Province. Festivus 28: 24-29.

101. Howard, A.D. 1952. Pteropods collected by the Allan Hancock Foundation. Minutes of the Conchological Club of Southern California, No. 121, pp. 12-14.

102. Hoyle, W.E. 1904. Reports on the dredging operations off the west coast of Central America to the Galapagos, to the west coast of Mexico, and in the Gulf of California, in charge of Alexander Agassiz, carried on by the U. S. Fish Commission steamer "Albatross," during 1891, Lieut. Commander Z. L. Tanner, U.S.N., Commanding, XXIX. Reports on the Scientific results of the expedition to the tropical Pacific, in charge of Alexander Agassiz, on the U. S. Fish Commission steamer "Albatross," from August, 1899, to March, 1900, Commander Jefferson T. Moser, U. S. N., commanding, V. Cephalopoda. Bull. Mus. Comp. Zoöl., Harvard Coll. XLIII: 1-71.

103. Hutchings, P., A. Reid, \& R. Wilson. 1991. Perinereis (Polychaeta, Nereidiae) from Australia, with redescriptions of six additional species. Rec. Australian Mus. 43: 241-274.

104. Iwamoto, T. \& Y.I. Sazonov. 1988. A review of the southeastern Pacific Coryphaenoides (sensu lato) (Pisces, Gadiformes, Macrouridae). Proc. California Acad. Sci. 45: 35-82.

105. Iwamoto, T. \& J.E. McCosker. 2001. Notes on Galápagos grenadiers (Pisces, Gadiformes, Macrouridae), with the description of a new species of Coryphaenoides. Rev. Biol. Trop. 49 (Suppl. 1): 21-27.

106. Jiménez-Cueto, S., E. Suárez-Morales \& Á. MoralesRamírez. 2012. Algunos poliquetos holoplanctónicos (Annelida: Polychaeta) del Parque Nacional de Isla del Coco, Costa Rica. Rev. Biol. Trop. 60 (Suppl. 3): 207-222.

107. Kabat, A.R. 2000. Results of the Rumphius Biohistorical Expedition to Ambon (1990). Part 10. Mollusca, Gastropoda, Naticidae. Zool. Med. Leiden 73: 345-380.

108. Kaiser, K.L. 2001. Comments on four Muricoidean (Mollusca) species formerly endemic to Isla del Coco found at Isla de Malpelo. Festivus 33: 3-7.

109. Kelmo, F. \& R. Vargas. 2002. Anthoathecatae and Leptothecatae hydroids from Costa Rica (Cnidaria: Hydrozoa). Rev. Biol. Trop. 50: 599-627.

Knowlton, N. 2000. Molecular genetic analyses of species boundaries in the sea. Hydrobiologia 420: 73-90.

110. Laguarda-Figueras A. \& F.A. Solís-Marín. 2009. Holothuria (Cystipus) casoae a new species of sea cucumber (Echinodermata: Holothuroidea) from the central-eastern Pacific Ocean. Scient. Mar. 73: 573-578.

111. Lalicker, C.G. \& I. McCulloch. 1940. Some Textulariidae of the Pacific Ocean. Allan Hancock Pac. Exped. 6: $115-143$.

112. Lattig, P. \& S.D. Cairns. 2000. A new species of Tethocyathus (Cnidaria: Anthozoa: Scleractinia: Caryophy1liidae), a trans-isthmian azooxanthellate species. Proc. Biol. Soc. Washington 113: 590-595.

Lessios, H.A. \& D.R. Robertson. 2006. Crossing the impassable: genetic connections in 20 reef fishes across the Eastern Pacific Barrier. Proc. R. Soc. Lond B 273:.2201-2208.

113. Lessios, H.A., B.D. Kessing \& D.R. Robertson. 1998. Massive gene flow across the world's most potent marine biogeographic barrier. Proc. R. Soc. Lond. B 265:583-588.

114. Lindberg, D.R. \& J.H. McLean. 1981. Tropical Eastern Pacific limpets of the Family Acmaeidae (Mollusca, Archaeogastropoda): Generic criteria and description of six new species from the mainland and the Galápagos Islands. Proc. California Acad. Sci. 42: 323-339. 
Lizano, O.G. 2008. Dinámica de aguas alrededor de la Isla del Coco, Costa Rica. Rev. Biol. Trop. 56 (Supl. 2): 31-48.

115. Long, D.J., J.E. McCosker, S. Blum \& A. Klapfer. 2011. Tropical Eastern Pacific Records of the Prickly Shark, Echinorhinus cookei (Chondrichthyes: Echinorhinidae). Pac. Sci. 65: 433-440.

116. López-Garro, A., I. Zanella, G. Golfín-Duarte \& M. Pérez-Montero. 2012. First record of the blacktip reef shark Carcharhinus melanopterus (Quoy \& Gaimard, 1824) (Carcharhiniformes: Carcharhinidae) from the Eastern Tropical Pacific. Rev. Biol. Trop. 60 (Suppl. 3): $275-278$

117. Ludwig, H.L. 1905. Reports on an exploration off the West Coast of Mexico, Central and South America, and off the Galapagos islands, in charge of Alexander Agassiz, by the U. S. Fish Commision steamer "Albatros", during 1891. XXXV. Reports on the Scientific results of the expedition to the Tropical Pacific in Charge of A. Agassiz on the Fish Commision Steamer "Albatros", from August, 1899, to March, 1900. VII. Asteroidea. Mem. Mus. Comp. Zoöl., Harvard Coll. XXXII: 1-292.

118. Magaña-Cubillo, J.A. \& J. Espinosa. 2009. Bivalves. Text: 387-398, Species list, CD: 348-378. In: I.S. Wehrtmann \& J. Cortés (Eds.). Marine Biodiversity of Costa Rica, Central America. Springer, Berlin.

119. Maluf, L.Y. 1991. Echinoderm fauna of the Galápagos Islands. Pp. 345-367. In: M. J. James (Ed.). Galápagos Marine Invertebrates: Taxonomy, Biogeography, and Evolution in Darwin's Islands. Plenum Press, New York and London.

Manning, R.B. 1972. Three new stomatopod crustaceans of the Family Lysiosquillidae from the eastern Pacific Region. Proc. Biol. Soc. Washington 85: 271-278.

120. May-Collado, L. 2009. Marine mammals. Text: 479 495, Species list, CD: 485-490. In: I.S. Wehrtmann \& J. Cortés (Eds.). Marine Biodiversity of Costa Rica, Central America. Springer, Berlin.

121. McCosker, J.E. 1988. A revision of the snake-eel genus Callechelys (Anguilliformes: Ophichthidae) with the description of two new Indo-Pacific species and a new callechelyin genus. Proc. California Acad. Sci. 50: 185-215.

122. McCosker, J.E. \& R.H. Rosenblatt. 2010. The fishes of the Galápagos archipelago: an update. Proc. California Acad. Sci, Ser. 4, 61 (Suppl. II): 167-195.

123. McCosker, J.E., J.S. Stephens \& R.H. Rosenblatt. 2003. Cottoclinus canops, a new genus and species of blenny (Perciformes: Labrisomidae) from the Galápagos Islands. Proc. California Acad. Sci. 54: 155-160.

124. McLaughlin, P.A. 1982. Revision of Pylopagurus and Tomopagurus (Crustacea: Decapoda: Paguridae), with the descriptions of new genera and species: Part III. Agaricochirus McLaughlin, and Enallopaguropsis McLaughlin. Bull. Mar. Sci. 32: 823-856.

125. McLean, J.H. 1969. New species of tropical eastern Pacific Gastropoda. Malac. Rev. 2: 115-130.

126. Meisler, M.R. \& R.J. Lavenberg. 1998. A new species (Serranidae: Serranus) from Isla del Coco, Pp. 115. In: G.R. Allen \& D.R. Robertson (Eds.). Peces del Pacífico Oriental Tropical. Crawford House Press, Bathhurst, Australia.

127. Møller, P.R., W. Schwarzhans \& J.G. Nielsen. 2005. Review of the American Dinematichyini (Teleostei: Bythitidae). Part II. Ogilbia. Aqua 10: 133-207.

128. Montoya, M. 2008a. Aves marinas de la Isla del Coco, Costa Rica, y su conservación. Rev. Biol. Trop. 56 (Suppl. 2): 133-149.

129. Montoya, M. 2008b. La presencia de otáridos (Carnivora: Otariidae) en la isla del Coco, Costa Rica. Rev. Biol. Trop. 56 (Suppl. 2): 151-158.

Montoya, M. \& K.L. Kaiser. 1988. Biogeographical notes on the genus Terebra (Gastropoda) at Isla del Coco, Costa Rica. Rev. Biol. Trop. 36: 569-574.

130. Morales-Ramírez, A. 2008. Caracterización cualitativa del zooplancton del Área de Conservación Marina Isla del Coco (ACMIC), Océano Pacífico de Costa Rica. Rev. Biol. Trop. 56 (Suppl. 2): 159-169.

131. Morales-Ramírez, A. \& E. Suárez-Morales. 2009. Copepods. Text: 291-305, Species list, CD: 224-236. In: I.S. Wehrtmann \& J. Cortés (Eds.). Marine Biodiversity of Costa Rica, Central America. Springer, Berlin.

132. Motomura, H. 2004. New species of scorpionfish, Scorpaena cocosensis (Scorpaeniformes: Scorpaenidae) from the Cocos Islands, Costa Rica, eastern Pacific Ocean. Copeia 2004: 818-824.

Neuhaus, B. 2004. Description of Campyloderes cf. vanhoeffeni (Kinorhyncha, Cyclorhagida) from the Central American East Pacific Deep with a review of the genus. Meiofauna Mar. 13: 3-20.

Neuhaus, B. \& T. Blasche. 2006. Fissuroderes, a new genus of Kinorhyncha (Cyclorhagida) from the deep sea and continental shelf of New Zealand and from the continental shelf of Costa Rica. Zool. Anz. 245: 19-52.

Nova-Bustos, N., A.C. Hernández-Zanuy \& R. ViquezPortuguez. 2010. Distribución y abundancia de las ascidias de los fondos rocosos de la Bahía de Cuajiniquil, Costa Rica. Bol. Invest. Mar. Cost. 39: 57-66.

133. Osburn, R.C. 1950. Bryozoa of the Pacific Coast of America. Part 1, Cheilostomata-Anasca. Allan Hancock Pac. Exped. 14: 1-269. 
134. Osburn, R.C. 1952. Bryozoa of the Pacific Coast of America. Part 2, Cheilostomata-Ascophora. Allan Hancock Pac. Exped. 14: 271-611.

135. Osburn, R.C. 1953. Bryozoa of the Pacific Coast of America. Part 3, Cyclostomata, Ctenostomata, Entoprocta, and Addenda. Allan Hancock Pac. Exped. 14: 613-725.

136. Perger, R., R. Vargas \& A. Wall. 2011. Johngarthia cocoensis, a new species of Gecarcinidae MacLeay, 1838 (Crustacea, Decapoda, Brachyura) from Cocos Island, Costa Rica. Zootaxa 2911: 57-68.

Petrescu, I., R.W. Heard, R. Vargas \& O. Breedy. 2009. Cumaceans. Text: 237-244, Species list, CD: 201203. In: I.S. Wehrtmann \& J. Cortés (Eds.). Marine Biodiversity of Costa Rica, Central America. Springer, Berlin

137. Petuch, E.J. \& D.M. Sargent. 1986. Atlas of the Living Olive Shells of the World. Coastal Education and Research Foundation, Jacksonville. 253 p.

Polidoro, B.A., T. Brooks, K.E. Carpenter, G.J. Edgar, S. Henderson, J. Sanciangco \& D.R. Robertson. 2012. Patterns of extinction risk and threat for marine vertebrates and habitat-forming species in the Tropical Eastern Pacific. Mar. Ecol. Prog. Ser. 448: 93-104.

138. Poss, S.G., J.E. McCosker \& C.C. Baldwin. 2010. A new species of Scorpaenodes (Pisces: Scorpaenidae) from the Galápagos and Cocos islands with discussions of the limits of Scorpaenodes and Thysanichthys. Proc. California Acad. Sci. 61: 235-267.

139. Price, W.W., R.W. Heard \& R. Vargas. 2009. Shallow water mysids. Text: 229-236, Species list, CD: 199200. In: I.S. Wehrtmann \& J. Cortés (Eds.). Marine Biodiversity of Costa Rica, Central America. Springer, Berlin.

140. Randall, J.E. \& J.E. McCosker. 1975. The eels of Easter Island with a description of a new moray. Contrib. Sci., Nat. Hist. Mus. Los Angeles County 264: 1-32.

141. Reiswig, H.M. 2010. A new species of Tretodictyum (Porifera: Hexactinellida: Tretodictyidae) from off Cocos Island, tropical eastern Pacific Ocean. Proc. Biol. Soc. Washington 123: 242-250.

142. Robertson, D.R. \& G.R. Allen. 2008. Shorefishes of the Tropical Eastern Pacific online information system. Version 1.0. Smithsonian Tropical Research Institute, Balboa, Panamá. www.neotropicalfishes. org/sftep, www.stri.org/sftep

Robertson, D.R. \& K.L. Cramer. 2009. Shore fishes and biogeographic subdivisions of the Tropical Eastern Pacific. Mar. Ecol. Prog. Ser. 380: 1-17.

143. Robertson, D.R., J.S. Grove \& J.E. McCosker. 2004. Tropical transpacific shore fishes. Pac. Sci. 58: 507-565.

144. Robson, G.C. 1929. A monograph of the Recent Cephalopoda based on the collections in the British
Museum (Natural History). Part 1. Octopodinae. Printed by order of the Trustees of the British Museum, July 27: 1-236.

145. Robson, G.C. 1932. A monograph of the Recent Cephalopoda based on the collections in the British Museum (Natural History). Part 2. Octopoda. Printed by order of the Trustees of the British Museum, January 23: 1-359.

146. Robson, G.C. 1948. The Cephalopoda Decapoda of the Arcturus Oceanographic Expedition, 1925. Zoologica 33: 115-132.

147. Rodríguez-Saénz, K. 2005. Distribución espacial y temporal de la biomasa, composición y abundancia del zooplancton, con énfasis en hidromedusas de Bahía Culebra durante La Niña 1999-2000. M.Sc. Tesis, Univ. Costa Rica, San Pedro, Costa Rica. $156 \mathrm{p}$.

148. Rodríguez-Sáenz, K. \& R. Gasca. 2009. Siphonophores. Text: 151-156, Species list, CD: 101-104. In: I.S. Wehrtmann \& J. Cortés (Eds.). Marine Biodiversity of Costa Rica, Central America. Springer, Berlin.

149. Rodríguez-Sáenz, K. \& L. Segura-Puertas. 2009. Hydrozoa, Scyphozoa and Cubozoa (Medusozoa). Text: 143-149, Species list, CD: 143-149. In: I.S. Wehrtmann \& J. Cortés (Eds.). Marine Biodiversity of Costa Rica, Central America. Springer, Berlin.

150. Rodríguez-Sevilla, L., R. Vargas \& J. Cortés. 2009. Benthic, shelled gastropods. Text: 333-355, Species list, CD: 243-325. In: I.S. Wehrtmann \& J. Cortés (Eds.). Marine Biodiversity of Costa Rica, Central America. Springer, Berlin.

151. Rosenblatt, R.H. \& J.E. McCosker. 1988. A new species of Acanthemblemaria from Malpelo Island, with a key to the Pacific members of the genus (Pisces: Chaenopsidae). Proc. California Acad. Sci. 45: 103-110.

152. Roth, B. \& E.V. Coan. 1971. Marginellidae (Mollusca: Neogastropoda) from the Galápagos Islands and Cocos Island. Proc. California Acad. Sci. $4^{\text {th }}$ Ser. 37: 575-584.

153. Rusch, D.B. +39 more authors. 2007. The Sorcerer II Global Ocean Sampling Expedition: northwest Atlantic through eastern tropical Pacific. PloS Biol. 5(3): e77. doi:101371/journal.pbio.0050077

Santoro, M. \& S. Mattiucci. 2009. Sea turtle parasites. Text: 507-519, Species list, CD: 497-500. In: I.S. Wehrtmann \& J. Cortés (Eds.). Marine Biodiversity of Costa Rica, Central America. Springer, Berlin.

154. Sasa, M., G.A. Chaves \& L.D. Patrick. 2009. Marine reptiles and amphibians. Text: 459-468, Species list, CD: 474-478. In: I.S. Wehrtmann \& J. Cortés (Eds.). Marine Biodiversity of Costa Rica, Central America. Springer, Berlin.

155. Schultz, L.P. 1944. A revision of the American clingfishes, Familia Gobiesocidae, with descriptions 
of new genera and forms. Proc. U.S. Nat. Mus. 96: 47-77.

156. Schwabe, E. \& I.S. Wehrtmann. 2009. Chitons. Text: 323-331, Species list, CD: 240-242. In: I.S. Wehrtmann \& J. Cortés (Eds.). Marine Biodiversity of Costa Rica, Central America. Springer, Berlin.

157. Shoemaker, C.R. 1942. Amphipod crustaceans collected on the Presidential Cruise of 1938. Smithsonian Misc. Coll. 101: 1-52.

158. Sibaja-Cordero, J.A., J. Troncoso \& J. Cortés. 2012. The lancelet Asymmetron lucayanum complex in Cocos Island National Park, Pacific Costa Rica. Pac. Sci. 66: 521-526.

Silva-Benavides, A.M. 2009. Mangroves. Text: 123-130, Species list, CD: 73-78. In: I.S. Wehrtmann \& J. Cortés (Eds.). Marine Biodiversity of Costa Rica, Central America. Springer, Berlin.

159. Solis-Marín, F.A., J.J. Alvarado +70 more authors. 2013. Appendix, p. 543-654. In J.J. Alvarado \& F.A. Solís-Marín (ed.). Echinoderm Research and Diversity in Latin America. Springer, Berlin, Heidelberg.

160. Solano-Barquero, A. 2011. Macrofauna asociada a rodolitos en el Parque Nacional Isla del Coco, Costa Rica. Thesis, Escuela de Biología, Univ. Costa Rica, San Pedro, Costa Rica. 50 p.

161. Solórzano, A. 2004. Serpientes de Costa Rica: distribución, taxonomía e historia natural. Edit. INBio, Santo Domingo de Heredia, Costa Rica. 791 p.

162. Springer, M. 2009. Marine insects. Text: 313-322, Species list, CD: 239. In: I.S. Wehrtmann \& J. Cortés (Eds.). Marine Biodiversity of Costa Rica, Central America. Springer, Berlin.

163. Starr, R.M., K. Green \& E. Sala. 2012. Deep-water fish assemblages at Coco Island National Park and Las Gemelas Seamounts, Costa Rica. Rev. Biol. Trop. 60 (Suppl. 3): 347-362.

164. Stebbing, T.R.R. 1903. Amphipoda from Costa Rica. Proc. U.S. Nat. Mus. 26: 925-931.

165. Suárez-Morales, E. \& R. Gasca. 2012. A new Lepeophtheirus (Copepoda: Siphonostomatoida: Caligidae) from Isla del Coco, Costa Rica, Eastern Tropical Pacific. Rev. Biol. Trop. 60 (Suppl. 3): 235-242.

166. Suárez-Morales, E. \& A. Morales-Ramírez. 2001. Nuevo registro de Acartia (Planktacartia) negligens (Copepoda, Calanoida) en el Pacífico Tropical Oriental. Rev. Biol. Trop. 49: 1286.

167. Suárez-Morales, E. \& A. Morales-Ramírez. 2009. New species of Monstrilloida (Crustacea: Copepoda) from the Eastern Tropical Pacific. J. Nat. Hist. 43: 1257-1271.

168. Suárez-Morales, E., R.M. Hernández-Flores \& A. Morales-Ramírez. 2009. Chaetognaths or arrow worms. Text: 435-443, List of species: CD 409-410. In: I.S. Wehrtmann and J. Cortés (Eds.). Marine Biodiversity of Costa Rica, Central America. Springer, Berlín.

169. Thoma, B.P., R.W. Heard, R. Vargas. 2005. A new species of Parapinnixa (Decapoda: Brachyura: Pinnotheridae) from Isla del Coco, Costa Rica. Proc. Biol. Soc. Washington 118: 543-550.

Tokioka, T. 1971. A new species of Rhopalaea from the Pacific coast of Costa Rica (Tunicata, Ascidiacea). Publ. Seto Mar. Biol. Lab. XIX (2/3): 119-122.

Tokioka, T. 1972. On a small collection of ascidians from the Pacific coast of Costa Rica. Publ. Seto Mar. Biol. Lab. XIX(6): 383-408.

170. Tovar-Hernández, M.A. \& H. Dean. 2010. Four new species of fan worms (Polychaeta: Sabellidae) from worldwide localities. Scient. Mar. 74: 815-826.

171. Treadwell, A.L. 1928. Polychaetous annelids from the Arcturus Oceanographic Expedition. Zoologica 8: 449-485.

Ulken, A., R. Víquez, C. Valiente \& M. Campos. 1990. Marine fungi (Chytridiomycetes and Thraustochytriales) from a mangrove area at Punta Morales, Golfo de Nicoya, Costa Rica. Rev. Biol. Trop. 38: 243-250.

172. Valdés, Á. \& Y.E. Camacho-García. 2004. "Cephalaspidean" Heterobranchs (Gastropoda) from the Pacific Coast of Costa Rica. Proc. California Acad. Sci. 55: 459-497.

Van Name, W.G. 1945. The North and South American Ascidians. Bull. American Mus. Nat. Hist. 84: 1-476.

173. Van Syoc, R. 2009. Barnacles. Text: 283-289, Species list, CD: 219-223. In: I.S. Wehrtmann \& J. Cortés (Eds.). Marine Biodiversity of Costa Rica, Central America. Springer, Berlin.

Vargas, J.A. 1988a. Community structure of macrobenthos and the results of macropredator exclusion on a tropical mud flat. Rev. Biol. Trop. 36: 287-308.

Vargas, J.A. 1988b. A survey of the meiofauna of an eastern tropical Pacific intertidal mud flat. Rev. Biol. Trop. 36: 541-544.

174. Vargas, J.A. \& H.K. Dean. 2009. Sipunculans. Text: 175-180, Species list, CD: 119-121. In: I.S. Wehrtmann \& J. Cortés (Eds.). Marine Biodiversity of Costa Rica, Central America. Springer, Berlin.

175. Vargas, J.A. \& H.K. Dean. 2010. On Branchiostoma californiense (Cephalochordata) from the Gulf of Nicoya estuary, Costa Rica. Rev. Biol. Trop. 58: 1143-1148.

176. Vargas, R. 2009. Stomatopods. Text: 193-197, Species list, CD: 160-163. In: I.S. Wehrtmann \& J. Cortés (Eds.). Marine Biodiversity of Costa Rica, Central America. Springer, Berlin. 
177. Vargas-Castillo, R. \& I.S. Werhtmann. 2008. Stomatopods and decapods from Isla del Coco, Pacific Costa Rica. Rev. Biol. Trop. 56 (Suppl. 2): 79-97.

178. Vargas, R. \& I.S. Werhtmann. 2009. Decapod crustaceans. Text: 209-228, Species list, CD: 167-198. In: I.S. Wehrtmann \& J. Cortés (Eds.). Marine Biodiversity of Costa Rica, Central America. Springer, Berlin.

179. Vargas, R., S. Jesse \& M. Castro. 1996. Checklist of crustaceans (Decapoda and Stomatopoda), collected during the Victor Hensen Costa Rica expedition (1993/1994). Rev. Biol. Trop. 44 (Suppl. 3): 97-102.

180. Vargas-Montero, M., Á. Morales-Ramírez \& J. Cortés. 2012. Primer informe del género Gambierdiscus (Dinophyceae) en el Parque Nacional Isla del Coco, Pacífico Tropical Oriental. Rev. Biol. Trop. 60 (Suppl. 3): 187-199.

181. Víquez, R. \& P.E. Hargraves. 2009. Phytoplankton. Text: 97-108, Species list, CD: 1-16. In: I.S. Wehrtmann \& J. Cortés (Eds.). Marine Biodiversity of Costa Rica, Central America. Springer, Berlin.

182. Waller, T.R. 2007. The evolutionary and biogeographic origins of the endemic Pectinidae (Mollusca: Bivalvia) of the Galapagos Islands. J. Paleontol. 81: 929-950

Wehrtmann, I.S. \& J. Cortés (Editors). 2009. Marine Biodiversity of Costa Rica, Central America. Monographiae Biologicae, Volumen 86. Springer + Business Media B.V., Berlin. Text: 538 p., List of species in Compact Disk: 500 p.

Wehrtmann, I.S., J. Cortés \& S. Echeverría-Sáenz. 2009. Marine biodiversity of Costa Rica: perspectives and conclusions, Chapter V, 521-533. In: I.S. Wehrtmann and J. Cortés (Eds.). Marine Biodiversity of Costa Rica, Central America. Springer, Berlin.
183. Wicksten, M.K. \& R. Vargas. 2001. A new species of Thor Kingsley, 1878 (Crustacea: Decapoda: Caridea: Hippolytidae) from the tropical eastern Pacific. Proc. Biol. Soc. Washington 114: 139-144.

184. Williams, A.B. 1986. Mud shrimps, Upogebia, from the eastern Pacific (Thalassinoidea: Upogebiidae). San Diego Soc. Nat. Hist. Mem. 14: 1-60.

185. Williamson, S.J., D.B. Rusch, S. Yooseph, A.L. Halpern, K.B. Heidelberg, J.I. Glass, C. Andrews-Pfannkoch, D. Fadrosh, C.S. Miller, G. Sutton, M. Frazier, J.C. Venter. 2008. The Sorcerer II Global Ocean Sampling Expedition: Metagenomic characterization of viruses within aquatic microbial samples. PLoS ONE 3(1): e1456. doi:10.1371/journal.pone.0001456.

186. Wilson, H.V. 1904. Reports on an exploration off the west coasts of Mexico, Central and South America, and off the Galapagos Islands, in charge of Alexander Agassiz, by the US Fish Commission Steamer Albatross, during 1891, Lieut. Commander Z.L. Tanner U.S.N., commanding. XXX. The sponges. Mem. Mus. Comp. Zoöl., Harvard Coll. XXX: 1-164.

187. Young, B.E., K. Easley, R. Garrigues, B. Mactavish, P. Murgatroyd \& J.R. Zook. 2010. Swallow-tailed gull Creagrus furcatus in Costa Rica. Cotinga 32: 24-26.

188. Zullo, V.A. 1991. Zoogeography of shallow-water cirriped fauna of the Galápagos Islands and adjacent regions in the Tropical Eastern Pacific. Pp. 173-192. In: M.J. James (Ed.). Galápagos Marine Invertebrates: Taxonomy, Biogeography, and Evolution in Darwin's Islands. Plenum Press, New York and London. 
APPENDIX 1

Marine species reported from Isla del Coco National Park, Pacific Costa Rica

$\begin{array}{llr} & & \text { Species } \\ \text { Virus } & \text { 1. Viral talC sequences } & 185 \\ & \text { 2. P-SSM4-like phages } & 185 \\ \text { Bacteria and Archaea } & \text { 1. Possibly several species } & 153 \\ \text { Phylum CYANOBACTERIA, Class } & & \end{array}$

CYANOPHYCEAE

Order SYNECHOCOCCALES,

Family Synechococcaceae

1. Prochlorococcus sp.

Phylum MYZOZOA, Infraphylum

DINOFLAGELLATA,

Class PERIDINEA, Order Gonyaulacida,

Family Goniodomataceae

1. Gambierdiscus sp. 180

Family Ostreopsidaceae

2. Amphidinium carterae Hulburt, 1957

3. Coolia tropicalis Faust, 1995

4. Coolia cf. areolota 180

5. Ostreopsis siamensis Schmidt, 1901

Order Prorocentrida, Family Prorocentraceae

6. Prorocentrum compressum (Bailey, 1850) 180 Abé ex Dodge, 1975

7. Prorocentrum concavum Fukuyo, 1981

Phylum CHLOROPHYTA, Class BRYOPSIDOPHYCEAE,

Order BRyopsidales, Family Bryopsidaceae

Family Codiaceae

Family Caulerpaceae

1. Bryopsis pennata J.V. Lamouroux, $1809 \quad 74,76$

2. Derbesia marina (Lyngbye) Solier, $1846 \quad 74,76$

3. Codium picturatum F.F. Pedroche \& P.C. Silva, $1996 \quad 74,76$

4. Caulerpa peltata J.V. Lamouroux, 1809

5. Caulerpa racemosa (Forsskål) J. Agardh, 1873

6. Caulerpa serrulata (Forsskål) J. Agardh, $1837 \quad 74,76$

Family Udoteaceae

Order Dasycladales, Family Dasycladaceae

7. Boodleopsis verticillata E.Y. Dawson 1960

8. Acetabularia parvula Solms-Laubach, 1895

Class ULVOPHYCEAE, Order Cladophorales,

Family Cladophoraceae

9. Cladophora panamensis W.R. Taylor, $1945 \quad 74,76$

10. Cladophora sp.

Order Ulvales, Family Ulvaceae

11. Ulva flexuosa Wulfen, 1803

Phylum OCHROPHYTA, Class

PHAEOPHYCEAE

Order Dictyotales, Family Dictyotaceae

1. Dictyopteris delicatula J.V. Lamouroux, 1809

2. Dictyota stolonifera Dawson, $1962 \quad 74,76$

3. Dictyota sp. 74

4. Lobophora variegata (Lamouroux) Womersley ex $\quad 74,76$ Oliveira, 1977

5. Padina crispata Thivy, $1945 \quad 74,76$

Order ScytosiPhonales, Family Scytosiphonaceae

6. Rosenvingea intrincata (J. Agardh) Børgesen, $1914 \quad 74,76$

Phylum RHODOPHYTA, Class

FLORIDEOPHYCEAE

Order CoRallinales, Family Corallinaceae

1. Amphiroa spp.

2. Amphiroa minutissima Taylor, $1945 \quad 74,76$

3. Corallina sp. 74 


Family Hapalidaceae
Order GELIDIALES, Family Gelidiaceae
Order HildENBRANDIALES, Family Hildenbrandiaceae
Order NEMALIALES, Family Galaxauraceae
Order GIGARTINALES, Family Peyssonneliaceae
Order CERAMIALES, Family Ceramiaceae
Family Rhodomelaceae
Order GRACILARIALES, Family Gracilariaceae
Phylum FORAMINIFERA, Class
POLYTHALAMEA,
Order BULIMIDA, Family Bolivinidae
Family Buliminitidae
Order LAGENIDA, Family Nodosariidae

Order Lituolida, Family Ammodiscidae

Family Discamminidae

Family Haplophragmoididae

Family Hormosinidae

Family Nouriidae

Family Verneulinidae

Order Textulariida, Family Textulariidae

Order Trochamminidae, Family Trochamminidae

Family Vaginulinidae

Phylum PORIFERA,

\section{Class HEXACTINELLIDA}

Order AmPHiDISCOSIDA, Family Hyalonematidae Order HeXactinosida, Family Aphrocallistidae Family Euritidae

Family Tretodictyidae

Order LysSACINOSIDA, Family Rossellidae

Class DEMOSPONGIAE, Order SPIROPHORIDA Family Pachastrellidae
Species

4. Dermatholithon saxicolum (Lemoine) Setchell \&

74 Mason, 1943

5. Jania spp.

6. Lithothamnion sp.

7. Gelidium sp.

8. Hildenbrandia sp.

9. Galaxaura filamentosa R. Chou, 1945

10. Peyssonnelia rubra J.G. Agardh, 1851

11. Ceramium spp.

12. Polysiphonia mollis

13. Gracilaria sp.

74

74

74

74

74,76

74,76

74

74,76

74

$\begin{array}{ll}\text { 1. Bolivina tongi var. filacostata } & 49,56\end{array}$ (Cushman \& McCulloch, 1942)

2. Bulimina laevigata Brady, 1881 as Bolivina laevigata 49,56

3. Dentalina cf. jugosa $\quad 57,98$

4. Laevidentalina filiformis (d'Orbigny, 1826) as 98 Dentalina filiformis

5. Ammodiscus pacificus Cushman \& Valentine, 1930

6. Ammoscalaria compressa (Cushman \& McCulloch, 49, 55 1939) as Ammofrondicularia compressa

7. Haplophragmoides hancocki Cushman \& McCulloch, 1939

8. Reophax agglutinatus Cushman, 1913

9. Reophax excentricus Cushman, 1910

10. Nouria polymorphinoides Heron-Allen \& 98 Earland, 1914

11. Verneuilinulla advena (Cushman, 1922) as 49,55 Eggerelloides advenus

12. Textularia articulata d'Orbigny, 1846

13. Textularia conica d'Orbigny, 1839

14. Textularia corrugata Herron-Allen \& Earland, 1915

15. Textularia panamensis Cushman, 1918

16. Textularia schencki Cushman \& Valentine, $1930 \quad 98,111$

17. Deuterammina rotaliformis Heron-Allen \& Earland, $\quad 49,55$ 1911 as Trochammina rotaliformis

18. Polystomammina nitida (Brady, 1881) as $\quad 49,55$ Trochammina nitida

19. Trochammina charlottensis Cushman, $1925 \quad 49,55$

20. Vaginulina exilis Cushman \& McCulloch, $1950 \quad 49,57$

1. Hyalonema (Coscinonema) pateriferum Wilson, $1904 \quad 50,186$

2. Aphrocallistes vastus Schulze, $1886 \quad 50,186$

3. Eurete erectum Schulze, $1899 \quad 50,186$

4. Eurete sp. 50,186

*5. Tretodictyum cocosensis Reiswig, 2010

6. Acanthascus (Staurocalyptus) sp. 50, 186

7. Thenea fenestrata (Schmidt, 1880) 50, 186 


\begin{tabular}{|c|c|c|}
\hline & Species & Ref. $^{1}$ \\
\hline Order HaLichONDRIDA, Family Axinellidae & 8. Phakellia lamelligera Wilson, 1904 & 50,186 \\
\hline \multicolumn{3}{|l|}{ Phylum CNIDARIA, Class ANTHOZOA } \\
\hline Order Pennatulacea, Family Pennatulidae & 1. Ptilosarcus undulatus Verrill, 1865 & 20,21 \\
\hline \multirow[t]{2}{*}{ Family Virgulariidae } & 2. Stylatula cf. elongate & 21 \\
\hline & 3. Stylatula sp. & 21 \\
\hline Order Alcyonacea, Family Aquaumbridae & $\begin{array}{l}\text { 4. Aquaumbra klapferi Breedy, Van Ofwegen \& } \\
\text { Vargas, } 2012\end{array}$ & $23 \mathrm{a}$ \\
\hline Family Clavulariidae & 5. Rhodelinda sp. & 21 \\
\hline \multirow[t]{3}{*}{ Family Gorgoniidae } & 6. Leptogorgia alba (Duchassaing \& Michelotti, 1864) & 20,21 \\
\hline & *7. Leptogorgia tricorata Breedy \& Cortés, 2011 & 22 \\
\hline & *8. Pacifigorgia curta Breedy \& Guzmán, 2003 & 21,23 \\
\hline Family Isididae & 9. Isidella sp. & 21 \\
\hline Family Nephthiedae & 10. Anthomastus sp. & 21 \\
\hline \multirow[t]{2}{*}{ Family Plexauridae } & 11. Psammogorgia variabilis Studer, 1894 & 21 \\
\hline & 12. Paramuricea sp. & 21 \\
\hline Family Primonoidae & 13. Narella sp. & 21 \\
\hline \multirow[t]{2}{*}{ Order Actinaria, Family Isophelliidae } & 14. Telmatactis cricoides (Duchassaing, 1850) & 45 \\
\hline & 15. Telmatactis panamensis (Verrill, 1869) & 2 \\
\hline \multirow[t]{9}{*}{ Order ScleractinIA, Family Agariciidae } & 16. Gardineroseris planulata (Dana, 1846) & 46 \\
\hline & 17. Leptoseris papyracea (Dana, 1846) & 46 \\
\hline & 18. Leptoseris scabra Vaughan, 1907 & 46 \\
\hline & 19. Pavona chiriquensis Glynn et al., 2001 & 46 \\
\hline & 20. Pavona clavus (Dana, 1846) & 46 \\
\hline & 21. Pavona gigantea Verrill, 1869 & 46 \\
\hline & 22. Pavona maldivensis (Gardiner, 1905) & 46 \\
\hline & 23. Pavona varians Verrill, 1864 & 46 \\
\hline & 24. Pavona xarifae Scheer \& Pillai, 1974 & 46 \\
\hline \multirow[t]{7}{*}{ Family Caryophylliidae } & *25. Anomocora carinata Cairns, 1991 & 36,46 \\
\hline & 26. Caryophyllia diomedeae Marenzeller, 1904 & 36,46 \\
\hline & 27. Caryophyllia perculta Cairns, 1991 & 36,46 \\
\hline & 28. Coenocyathus bowersi Vaughan, 1906 & 36,46 \\
\hline & 29. Desmophyllum dianthus (Esper, 1794) & 36,46 \\
\hline & 30. Polycyathus hondaensis (Durham \& Barnard, 1952) & 36,46 \\
\hline & 31. Tethocyathus prahli Lattig \& Cairns 2000 & 46,112 \\
\hline \multirow[t]{4}{*}{ Family Dendrophylliidae } & 32. Dendrophyllia oldroydae Oldroyd, 1924 & 36,46 \\
\hline & 33. Endopachys grayi Milne Edwards \& Haime, 1848 & 36,46 \\
\hline & 34. Rhizopsammia verrilli Van der Horst, 1922 & 36,46 \\
\hline & 35. Tubastrea coccinea Lesson, 1829 & 36,46 \\
\hline Family Faviidae & 36. Cladocora pacifica Cairns, 1991 & 36,46 \\
\hline Family Flabellidae & 37. Javania cailleti (Duchassaing \& Michelotti, 1864) & 36,46 \\
\hline \multirow[t]{2}{*}{ Family Fungiidae } & 38. Fungia (Cycloseris) curvata Hoeksema, 1989 & 36,46 \\
\hline & 39. Fungia (Cycloseris) distorta Michelin, 1842 & 36,46 \\
\hline \multirow[t]{4}{*}{ Family Pocilloporidae } & 40. Pocillopora damicornis (Linnaeus, 1758) & 46 \\
\hline & 41. Pocillopora elegans Dana, 1846 & 46 \\
\hline & 42. Pocillopora eydouxi Milne Edwards \& Haime, 1860 & 46 \\
\hline & 43. Pocillopora meandrina Dana, 1846 & 46 \\
\hline Family Poritidae & 44. Porites lobata Dana, 1846 & 46 \\
\hline \multirow[t]{2}{*}{ Family Rhizangiidae } & 45. Astrangia dentata Verrill, 1866 & 36,46 \\
\hline & 46. Culicia stellata Dana, 1846 & 36,46 \\
\hline
\end{tabular}




\begin{tabular}{|c|c|c|}
\hline & Species & Ref. $^{1}$ \\
\hline \multirow[t]{2}{*}{ Family Siderastreidae } & 47. Psammocora stellata (Verrill, 1866) & 46 \\
\hline & 48. Psammocora superficialis Gardiner, 1898 & 46 \\
\hline \multicolumn{3}{|l|}{ Class SCYPHOZOA, Order CORONATAE } \\
\hline \multirow[t]{4}{*}{ Family Atollidae } & 49. Atolla sp. & 15,16 \\
\hline & 50. Atolla wyvillei Haeckel, 1880 & 15,16 \\
\hline & 51. Periphylla hyacinthina (Péron \& Lesueur, 1810) & 15,16 \\
\hline & 52. Periphylla sp. & 15,16 \\
\hline Family Atorellidae & 53. Atorella arcturi Bigelow, 1928 & 16 \\
\hline Family Linuchidae & 54. Linuche unguiculata (Swartz, 1788) & 16 \\
\hline Order SEMAEOSTOMEAE, Family Pelagiidae & 55. Pelagia noctiluca (Forskål, 1775) & 16 \\
\hline \multicolumn{3}{|l|}{ Class HYDROZOA } \\
\hline Order AnthoAthecata, Family Polyorchidae & 56. Polyorchis penicillatus (Eschscholtz, 1829) & 149 \\
\hline \multirow[t]{5}{*}{ Family Stylasteridae } & 57. Errina macrogastra Marenzeller, 1904 & 37,46 \\
\hline & *58. Pliobothrus fistulosus Cairns, 1991 & 37,46 \\
\hline & *59. Stylaster cocosensis Cairns, 1991 & 37,46 \\
\hline & 60. Stylaster galapagensis Cairns, 1986 & 37,46 \\
\hline & 61. Stylaster marenzelleri Cairns, 1986 & 37,46 \\
\hline \multirow[t]{2}{*}{ Order LEPTOTHЕСАTA, Family Campanulariidae } & $\begin{array}{l}\text { 62. Clytia gracilis (Sars, 1850) as C. cylindrica and as } \\
\text { Gonothyraea gracilis }\end{array}$ & $44,80,109$ \\
\hline & $\begin{array}{l}\text { 63. Obelia dichotoma (Linnaeus, } 1758 \text { ) as } \\
\text { O. commissuralis }\end{array}$ & $44,80,98$ \\
\hline Family Haleciidae & 64. Halecium washingtoni Nutting, 1901 & $80,81,98$ \\
\hline Family Sertulariidae & 65. Thuiaria crisioides Lamouoroux, 1824 & 81,98 \\
\hline \multicolumn{3}{|l|}{ Order TRACHYMEDUSAE, } \\
\hline Other Hydromedusae & 67-68. Two undentified species in two families & 130 \\
\hline \multicolumn{3}{|l|}{$\begin{array}{l}\text { Subclass SIPHONOPHORAE, } \\
\text { Order CALYCOPHORAE }\end{array}$} \\
\hline \multirow[t]{2}{*}{ Family Abylidae } & 69. Abylopsis sp. & 17,130 \\
\hline & 70. Abylopsis tetragona $(\mathrm{Otto}, 1823)$ & 17,130 \\
\hline \multirow[t]{4}{*}{ Family Dyphidae } & 71. Dyphes dispar (Chamisso \& Eysenhardt, 1821) & 17,130 \\
\hline & 72. Dyphes sp. & 17,130 \\
\hline & 73. Eudoxoides mitra (Huxley, 1859) & 17,130 \\
\hline & 74. Muggiaea atlantica Cunningham, 1892 & 17,130 \\
\hline Family Hippopodiidae & 75. Vogtia serrata (Moser, 1925) & 17 \\
\hline \multirow[t]{3}{*}{ Family Prayidae } & 76. Nectadamas diomedeae (Bigelow, 1911) & 17 \\
\hline & 77. Nectopyramis natans (Bigelow, 1911) & 17 \\
\hline & 78. Praya dubia (Quoy \& Gaimard, 1827) & 17 \\
\hline \multirow[t]{2}{*}{ Order PHYSONECTAE, Family Agalmatidae } & 79. Agalma okenis Eschscholtz, 1825 & 17,147 \\
\hline & 80. Halistemma sp. & 17,147 \\
\hline Family Athorybiidae & 81. Athorybia rosacea (Forskål, 1775) & 17 \\
\hline Family Forskaliidae & 82. Forskalia sp. & 17 \\
\hline Family Physophoridae & 83. Physophora hydrostatica Forskål, 1775 & 17 \\
\hline \multicolumn{3}{|l|}{ Phylum MOLLUSCA, Class } \\
\hline \multicolumn{3}{|l|}{ POLYPLACOPHORA } \\
\hline \multirow[t]{2}{*}{ Order CHITONIDA, Family Acanthochitonidae } & 1. Acanthochitona angelica Dall, 1919 & 156,160 \\
\hline & 2. Acanthochitona hirudiniformis (Sowerby, 1832) & 156 \\
\hline \multirow[t]{2}{*}{ Family Chitonidae } & 3. Chiton goodallii Broderip \& Sowerby, 1832 & 60,156 \\
\hline & 4. Chiton stokesii Broderip, 1832 & $60,78,156$ \\
\hline
\end{tabular}




Family Ischnochitonidae
Family Mopaliidae
Class GASTROPODA, Family Aeolidiidae
Family Aglajidae
Family Architectonicidae

Family Amathinidae

Family Areneidae

Family Atlantidae

Family Barleeiidae

Family Buccinidae

Family Bullidae

Family Bursidae

Family Caecidae

Family Calyptraeidae

\section{Species}

*5. Ischnochiton victoriae Ferreira, 1987

78,156

6. Lepidozona rothi Ferreira, 1983

78,156

7. Stenoplax boogii (Haddon, 1886)

78,156

8. Placiphorella blainvillei (Broderip, 1832)

78,156

9. Aeolidiella indica Bergh, 1888

10. Navanax aenigmaticus (Bergh, 1894)

11. Architectonica nobilis Röding, 1798

12. Discotectonica placentalis (Hinds, 1844)

150

13. Heliacus mazatlanicus Pilsbry \& Lowe, 1932

150

14. Pseudotorinia architae (O.G. Costa, 1841) 150

15. Psilaxis radiata (Röding, 1798) 150

16. Phasianema saxicola (C.B. Adams, 1852) 150

17. Arene ferruginosa McLean, $1970 \quad 150$

18. Arene guttata McLean, $1970 \quad 150$

19. Atlanta sp. 130

20. Barleeia cf. bifasciata 150

21. Barleeia orcutti Bartsch, $1920 \quad 150$

22. Barleeia paupercula (C.B. Adams, 1852) 150

23. Barleeia polychroma (de Folin, 1870) 150

24. Amphithalamus inclusus Carpenter, 1864

25. Bailya anomala (Hinds, 1844) 150

26. Caducifer cinis (Reeve, 1846) 150

27. Cantharus gemmatus (Reeve, 1846) 150

28. Cantharus rehderi Berry, $1962 \quad 150$

29. Cantharus sanguinolentus (Duclos, 1833) 150

30. Clivipollia fragaria (Wood, 1828) 150

31. Colubraria lucasensis Strong \& Hertlein, 1937

32. Colubraria ochsneri Hertlein \& Allison, $1968 \quad 150$

33. Engina jugosa (C.B. Adams, 1852) 150

34. Phos articulatus Hinds, $1844 \quad 150$

35. Phos cocosensis Dall, $1896 \quad 98$

36. Phos crassus Hinds, $1843 \quad 150$

37. Bulla punctulata A. Adams in Sowerby, 1850

38. Bursa calcipicta Dall, $1908 \quad 150$

39. Bursa corrugata (Perry, 1811) 150

40. Bursa granularis (Röding, 1798) 150

41. Marsupina nana (Broderip \& Sowerby, 1829) 150

42. Caecum clathratum Carpenter, 1857

43. Caecum cf. corrugulatum 150

44. Caecum laqueatum C.B. Adams, 1852

45. Caecum lohri (Strong \& Hertlein, 1939) 150

46. Caecum paradoxum de Folin, $1867 \quad 150$

47. Caecum parvum C.B. Adams, $1852 \quad 150$

48. Elephantulum heptagonum (Carpenter, 1857) 150

49. Elephantulum liratocinctum (Carpenter, 1857) 150

50. Fartulum glabriforme (Carpenter, 1857) 150

51. Cheilea cepacea (Broderip, 1834) 150

52. Cheilea corrugata (Broderip, 1834) 150

53. Crucibulum scutellatum (Wood, 1928) 150 


\begin{tabular}{|c|c|c|}
\hline & Species & Ref. $^{1}$ \\
\hline \multirow[t]{3}{*}{ Family Cancellariidae } & 54. Cancellaria pulchra Sowerby, 1832 & 150 \\
\hline & 55. Sveltia centrota (Dall, 1896) & 150 \\
\hline & 56. Trigonostoma breve (Sowerby, 1832) & 150 \\
\hline Family Carinariidae & 57. Cardiapoda placenta (Lesson, 1830) & 130 \\
\hline \multirow[t]{4}{*}{ Family Cassidae } & 58. Casmaria vibexmexicana (Stearns, 1894) & 150 \\
\hline & 59. Cypraecassis coarctata (Sowerby, 1825) & 150 \\
\hline & 60. Cypraecassis tenuis (Wood, 1928) & 150 \\
\hline & 61. Semicassis centiquadrata (Valenciennes, 1832) & 150 \\
\hline \multirow[t]{5}{*}{ Family Cavoliniidae } & $\begin{array}{l}\text { 62. Diacavolinia longirostris (Blainville, 1821) as } \\
\text { Cavolina logirostris }\end{array}$ & 98,101 \\
\hline & 63. Clio sp. & 130 \\
\hline & 64. Creseis virgula Rang, 1828 as Creseus virgula & 98,101 \\
\hline & 65. Cuvierina sp. & 130 \\
\hline & 66. Diacria quadridentata (Lesueur, 1821) & 98,101 \\
\hline \multirow[t]{4}{*}{ Family Cerithiidae } & 67. Cerithium adustum Kiener, 1841 & 60,150 \\
\hline & 68. Cerithium maculosum Kiener, 1841 & 60,150 \\
\hline & 69. Cerithium uncinatum (Gmelin, 1791) & 60,150 \\
\hline & 70. Rhinoclavis gemmata (Hinds, 1844) & 60,150 \\
\hline \multirow[t]{4}{*}{ Family Cerithiopsidae } & 71. Cerithiopsis adamsi Bartsch, 1911 & 150,160 \\
\hline & 72. Seila assimilata (C.B. Adams, 1852) & 150 \\
\hline & 73. Seila kanoni (de Folin, 1867) & 150 \\
\hline & 74. Seila pulmoensis DuShane \& Draper, 1975 & 150 \\
\hline \multirow[t]{2}{*}{ Family Chromodorididae } & 75. Chromodoris sphoni Ev. Marcus, 1971 & 38 \\
\hline & 76. Glossodoris baumanni (Bertsch, 1970) & 38 \\
\hline \multirow[t]{9}{*}{ Family Columbellidae } & 77. Aesopus chrysalloides (Carpenter, 1864) & 150 \\
\hline & 78. Aesopus sanctus Dall, 1919 & 150 \\
\hline & 79. Columbella labiosa Sowerby, 1822 & 150 \\
\hline & 80. Columbella sonsonatensis (Mörch, 1860) & 150 \\
\hline & 81. Cotonopsis deroyae (Emerson \& D’Attilio, 1969) & 150 \\
\hline & 82. Microcithara uncinata (Sowerby, 1832) & 150 \\
\hline & 83. Mitrella ocellata (Gmelin, 1791) & 150 \\
\hline & 84. Steironepion melanosticta (Pilsbry \& Lowe, 1932) & 150 \\
\hline & 85. Zafrona incerta (Stearns, 1892) & 150 \\
\hline \multirow[t]{15}{*}{ Family Conidae } & 86. Conus brunneus Wood, 1828 & 150 \\
\hline & 87. Conus chaldaeus (Röding, 1798) & 150 \\
\hline & 88. Conus dalli Stearns, 1873 & 150 \\
\hline & 89. Conus diadema Sowerby, 1834 & 150 \\
\hline & 90. Conus ebraeus Linnaeus, 1758 & 150 \\
\hline & 91. Conus emarginatus Reeve, 1844 & 150 \\
\hline & 92. Conus gladiator Broderip, 1833 & 150 \\
\hline & 93. Conus gradatus Wood, 1828 & 150 \\
\hline & 94. Conus lucidus Wood, 1828 & 150 \\
\hline & 95. Conus mahogani Reeve, 1843 & 150 \\
\hline & 96. Conus nux Broderip, 1833 & 150 \\
\hline & 97. Conus purpurascens Sowerby, 1833 & 150 \\
\hline & 98. Conus recurvus Broderip, 1833 & 150 \\
\hline & 99. Conus tessulatus Born, 1778 & 150 \\
\hline & 100. Conus tiaratus Sowerby, 1833 & 150 \\
\hline
\end{tabular}




\begin{tabular}{|c|c|c|}
\hline & Species & Ref. $^{1}$ \\
\hline \multirow[t]{10}{*}{ Family Coralliophilidae } & 101. Babelomurex hindsii (Carpenter, 1857) & 150 \\
\hline & $\begin{array}{l}\text { 102. Babelomurex santacruzensis } \\
\text { (Emerson \& D'Attilio, 1970) }\end{array}$ & 150 \\
\hline & 103. Coralliophila macleani Shasky, 1970 & 150 \\
\hline & 104. Coralliophila neritoidea (Lamarck, 1816) & 150 \\
\hline & 105. Coralliophila parva (E.A. Smith, 1877) & 150 \\
\hline & 106. Coralliophila rocasuciae Myers \& D'Attilio, 1990 & 150 \\
\hline & 107. Coralliophila violacea (Kiener, 1836) & 69 \\
\hline & 108. Quoyula madreporarum (Sowerby, 1834) & 150 \\
\hline & 109. Reliquiaecava robillardi (Liénard, 1870) & 150 \\
\hline & 110. Rhizochilus antipathum Steenstrup, 1850 & 150 \\
\hline Family Costellariidae & 111. Thala jeancateae Sphon, 1969 & 150 \\
\hline Family Cylichnidae & 112. Cylichna atahualpa (Dall, 1908) & 172 \\
\hline \multirow[t]{11}{*}{ Family Cypraeidae } & 113. Blasicrura alisonae Burgess, 1983 & 150 \\
\hline & 114. Blasicrura rashleighana (Melvill, 1888) & 150 \\
\hline & 115. Blascicrura teres Gmelin, 1791 & 150 \\
\hline & 116. Erosaria albuginosa Gray, 1825 & 150 \\
\hline & 117. Erosaria caputserpentis Linnaeus, 1758 & 150 \\
\hline & 118. Luria isabellamexicana Stearns, 1893 & 150 \\
\hline & 119. Macrocypraea cervinetta (Kiener, 1843) & 150 \\
\hline & 120. Mauritia depressa (Gray, 1824) & 150 \\
\hline & 121. Monetaria moneta Linnaeus, 1758 & 150 \\
\hline & 122. Talparia talpa Linnaeus, 1758 & 150 \\
\hline & 123. Zonaria robertsi (Hidalgo, 1906) & 150 \\
\hline \multirow[t]{5}{*}{ Family Cystiscidae } & *124. Gibberula achenea Roth \& Coan, 1971 & 150,152 \\
\hline & 125. Gibberula minor (C.B. Adams, 1852) & 150 \\
\hline & 126. Gibberula polita (Carpenter, 1857) & 150 \\
\hline & 127. Gibberula subtrigona (Carpenter, 1864) & 150 \\
\hline & 128. Persicula pulchella (Kiener, 1834) & 150 \\
\hline Family Dendrodorididae & 129. Dendrodoris fumata (Rüpell \& Leuckart, 1831) & 38 \\
\hline Family Desmopteridae & 130. Desmopterus papilio Chun, 1889 & 124 \\
\hline Family Elachisinidae & 131. Elachisina johnstoni (Baker, Hanna \& Strong, 1930) & 150 \\
\hline \multirow[t]{6}{*}{ Family Ellobiidae } & 132. Ellobium stagnalis (d'Orbigny, 1835) & 60,150 \\
\hline & 133. Melampus carolianus (Lesson, 1842) & 60,150 \\
\hline & 134. Melampus tabogensis C.B. Adams, 1852 & 60,150 \\
\hline & 135. Melampus trilineatus (C.B. Adams, 1852) & 98 \\
\hline & 136. Pedipes angulatus C.B. Adams, 1852 & 60,150 \\
\hline & 137. Tralia panamensis (C.B. Adams, 1852) & 60,150 \\
\hline \multirow[t]{11}{*}{ Family Epitoniidae } & 138. Amaea deroyae DuShane, 1970 & 150 \\
\hline & 139. Epitonium acapulcanum Dall, 1917 & 150,160 \\
\hline & 140. Epitonium aciculinum (Hinds, 1844) & 150 \\
\hline & 141. Epitonium billeeanum (DuShane \& Bratcher, 1965) & 150 \\
\hline & 142. Epitonium hancocki DuShane, 1970 & 150 \\
\hline & 143. Epitonium indistinctum (Sowerby, 1844) & 150 \\
\hline & 144. Epitonium replicata (Sowerby, 1844) & 150 \\
\hline & 145. Opalia crystallina (Carpenter, 1864) & 150 \\
\hline & 146. Opalia infrequens (C.B. Adams, 1852) & 150 \\
\hline & 147. Opalia paulula DuShane, 1974 & 150 \\
\hline & 148. Opalia sanjuanensis (Lowe, 1932) & 150 \\
\hline
\end{tabular}




\begin{tabular}{|c|c|c|}
\hline & Species & Ref. $^{1}$ \\
\hline \multirow[t]{8}{*}{ Family Eulimidae } & 149. Eulima elegantissima de Folin, 1887 & 150 \\
\hline & 150. Melanella ogasawarana (Pilsbry, 1905) & 150 \\
\hline & 151. Melanella townsendi Bartsch, 1917 & 150 \\
\hline & 152. Niso aeglees Bush, 1885 & 150 \\
\hline & 153. Niso interrupta (Sowerby, 1834) & 150 \\
\hline & 154. Sabinella shaskyi Warén, 1992 & 150 \\
\hline & 155. Scalenostoma subulata (Broderip, 1832) & 150 \\
\hline & 156. Subniso rangii (de Folin, 1867) & 150 \\
\hline \multirow[t]{6}{*}{ Family Fasciolariidae } & 157. Leucozonia cerata (Wood, 1828) & 60,150 \\
\hline & 158. Leucozonia tuberculata (Broderip, 1833) & 60,150 \\
\hline & 159. Fusinus allyni McLean, 1970 & 60,150 \\
\hline & 160. Fusinus dupetitthouarsi (Kiener, 1840) & 60,150 \\
\hline & 161. Fusinus turris (Valenciennes, 1832) & 60,150 \\
\hline & 162. Pleuroploca princeps (Sowerby, 1825) & 60,150 \\
\hline \multirow[t]{7}{*}{ Family Fissurellidae } & 163. Diodora inaequalis (Sowerby, 1835) & 150 \\
\hline & 164. Diodora punctifissa McLean, 1970 & 150 \\
\hline & 165. Diodora saturnalis (Carpenter, 1864) & 150 \\
\hline & 166. Fissurella deroyae McLean, 1970 & 150 \\
\hline & 167. Fissurella microtrema Sowerby, 1835 & 150 \\
\hline & 168. Fissurella virescens Sowerby, 1835 & 150 \\
\hline & 169. Lucapinella milleri Berry, 1959 & 150 \\
\hline Family Haliotidae & *170. Haliotis dalli roberti McLean, 1970 & 125,150 \\
\hline \multirow[t]{2}{*}{ Family Harpidae } & 171. Harpa crenata Swainson, 1822 & 150 \\
\hline & 172. Morum veleroae Emerson, 1968 & 150 \\
\hline \multirow[t]{3}{*}{ Family Hipponicidae } & 173. Hipponix antiquatus panamensis C.B. Adams, 1852 & 150 \\
\hline & 174. Hipponix grayanus Menke, 1853 & 150 \\
\hline & 175. Pilosabia pilosa (Deshayes, 1832) & 150 \\
\hline Family Juliidae & 176. Julia thecaphora (Carpenter, 1857) & 38 \\
\hline \multirow[t]{2}{*}{ Family Limacinidae } & 177. Limacina inflata (d'Orbigny, 1836) & 98,101 \\
\hline & 178. Limacina trochiformis (d'Orbigny, 1836) & 130 \\
\hline Family Litiopidae & 179. Alaba supralirata Carpenter, 1857 & 150 \\
\hline \multirow[t]{9}{*}{ Family Littorinidae } & $\begin{array}{l}\text { 180. Echinolittorina aspera (Philippi, 1846) as } \\
\text { Littorina aspera }\end{array}$ & 98 \\
\hline & $\begin{array}{l}\text { 181. Echinolittorina modesta (Philippi, 1846) as } \\
\text { Nodilittorina modesta }\end{array}$ & 98 \\
\hline & 182. Littoraria coccinea (Gmelin, 1791) & 60,150 \\
\hline & 183. Littoraria pintado pullata (Carpenter, 1864) & 60,150 \\
\hline & 184. Littoraria undulata (Gray, 1839) & 60,150 \\
\hline & 185. Littorina keenae Rosewater, 1978 & 60,150 \\
\hline & 186. Nodilittorina atrata (C.B. Adams, 1852) & 60,150 \\
\hline & 187. Nodilittorina conspersa (Philippi, 1847) & 60,150 \\
\hline & 188. Nodilittorina dubiosa (C.B. Adams, 1852) & 60,150 \\
\hline \multirow[t]{5}{*}{ Family Lottidae } & 189. Lottia mesoleuca (Menke, 1851) & 150 \\
\hline & *190. Lottia rothi (Lindberg \& McLean, 1981) & 114,150 \\
\hline & 191. Lottia strigatella (Carpenter, 1864) & 150 \\
\hline & 192. Patelloida semirubida (Dall, 1914) & 150 \\
\hline & 193. Tectura ubiquita (Lindberg \& McLean, 1981) & 150 \\
\hline Family Marginellidae & 194. Volvarina taeniolata taeniolata Mörch, 1860 & 150,160 \\
\hline
\end{tabular}




\begin{tabular}{|c|c|c|}
\hline & Species & Ref. $^{1}$ \\
\hline \multirow[t]{15}{*}{ Family Mitridae } & 195. Mitra crenata Broderip, 1836 & $60,150,160$ \\
\hline & 196. Mitra effusa Broderip, 1836 & 60,150 \\
\hline & 197. Mitra ferruginea Lamarck, 1811 & 60,150 \\
\hline & 198. Mitra fultoni E.A. Smith, 1892 & 60,150 \\
\hline & 199. Mitra inca d'Orbigny, 1841 & 60,150 \\
\hline & 200. Mitra lens Wood, 1828 & 60,150 \\
\hline & 201. Mitra mitra (Linnaeus, 1758) & 60,150 \\
\hline & 202. Mitra papalis (Linnaeus, 1758) & 60,150 \\
\hline & 203. Mitra rupicola Reeve, 1844 & 60,150 \\
\hline & 204. Mitra sphoni Shasky \& Campbell, 1964 & 60,150 \\
\hline & 205. Mitra swainsonii swainsonii Broderip, 1836 & 60,150 \\
\hline & 206. Mitra tristis Broderip, 1836 & 60,150 \\
\hline & 207. Subcancilla attenuata (Broderip, 1836) & 60,150 \\
\hline & 208. Subcancilla erythrogramma (Tomlin, 1931) & 60,150 \\
\hline & 209. Subcancilla sulcata (Swainson in Sowerby, 1825) & 60,150 \\
\hline \multirow[t]{33}{*}{ Family Muricidae } & 210. Acanthais brevidentata (Wood, 1828) & 60,150 \\
\hline & 211. Acanthotrophon sentus Berry, 1969 & 60,150 \\
\hline & 212. Aspella hastula (Reeve, 1844) & 60,150 \\
\hline & 213. Aspella pollux Radwin \& D'Attilio, 1976 & 60,150 \\
\hline & 214. Aspella pyramidalis (Broderip, 1833) & 60,150 \\
\hline & 215. Bizetiella micaela Radwin \& D'Attilio, 1972 & 60,150 \\
\hline & 216. Chicoreus eversoni D’Attilio, Myers \& Shasky, 1987 & 60,150 \\
\hline & 217. Drupa ricinus (Linnaeus, 1758) & 69 \\
\hline & 218. Favartia cocosensis Myers \& D’Attilio, 1990 & 60,150 \\
\hline & 219. Favartia diomedaea (Dall, 1908) & 60,150 \\
\hline & 220. Favartia humilis (Broderip, 1833) & 60,150 \\
\hline & 221. Favartia incisa (Broderip, 1833) & 60,150 \\
\hline & 222. Favartia laurae (Vokes, 1970) & 60,150 \\
\hline & 223. Favartia mildredae (Poorman, 1980) & 60,150 \\
\hline & 224. Favartia purdyae Vokes \& D'Attilio, 1980 & 60,150 \\
\hline & 225. Favartia radwini (Emerson \& D'Attilio, 1970) & 60,150 \\
\hline & *226. Favartia shaskyi D'Attilio \& Myers, 1988 & 61,150 \\
\hline & 227. Hexaplex princeps (Broderip, 1833) & 60,150 \\
\hline & 228. Mancinella speciosa (Valenciennes, 1832) & 60,150 \\
\hline & 229. Mancinella triangularis (Blainville, 1832) & 60,150 \\
\hline & 230. Morula uva (Röding, 1798) & $60,150,160$ \\
\hline & 231. Murexiella humilis (Broderip, 1833) & 60,150 \\
\hline & 232. Muricopsis westonensis Myers \& D'Attilio, 1990 & 60,150 \\
\hline & 233. Muricopsis zeteki Hertlein \& Strong, 1951 & 60,150 \\
\hline & 234. Neorapana muricata (Broderip, 1832) & 60,150 \\
\hline & 235. Pascula rufonotata (Carpenter, 1864) & $60,150,160$ \\
\hline & 236. Phyllocoma scalariformis (Broderip, 1833) & 60,150 \\
\hline & 237. Plicopurpura columellaris (Lamarck, 1822) & 60,150 \\
\hline & 238. Plicopurpura patula pansa (Gould, 1853) & 60,150 \\
\hline & 239. Pterotyphis lowei lowei (Pilsbry, 1931) & 60,150 \\
\hline & 240. Stramonita biserialis (Blainville, 1832) & 60,150 \\
\hline & 241. Trachypollia lugubris (C.B. Adams, 1852) & 60,150 \\
\hline & 242. Tribulus planospira (Lamarck, 1822) & 60,150 \\
\hline
\end{tabular}




\begin{tabular}{|c|c|c|}
\hline & Species & Ref. $^{1}$ \\
\hline & 243. Vasula melones (Duclos, 1832) & 60,150 \\
\hline & 244. Vitularia salebrosa (King \& Broderip, 1832) & 60,150 \\
\hline \multirow[t]{2}{*}{ Family Nassariidae } & 245. Nassarius nassiformis Leson, 1842 & 150 \\
\hline & 246. Nassarius nodicinctus (A. Adams, 1852) & 150 \\
\hline \multirow[t]{8}{*}{ Family Naticidae } & 247. Eunaticina insculpta (Carpenter, 1865) & 150 \\
\hline & 248. Natica elenae Récluz, 1844 & 150 \\
\hline & 249. Natica grayi Philippi, 1852 & 150 \\
\hline & 250. Natica idiopoma Pilsbry \& Lowe, 1932 & 150 \\
\hline & 251. Polinices helicoides (Gray, 1825) & 150 \\
\hline & 252. Polinices otis (Broderip \& Sowerby, 1829) & 150 \\
\hline & 253. Polinices pardoanus Dall, 1908 & 150 \\
\hline & 254. Mammilla simiae (Deshayes, 1838) as Polinices siiae & $100,107,150$ \\
\hline \multirow[t]{3}{*}{ Family Neritidae } & 255. Nerita funiculata Menke, 1851 & 60,150 \\
\hline & 256. Nerita scabricosta Lamarck, 1822 & 60,150 \\
\hline & 257. Neritina latissima Broderip, 1833 & 60,150 \\
\hline \multirow[t]{4}{*}{ Family Olividae } & 258. Oliva foxi Stingley, 1984 & 150 \\
\hline & 259. Oliva spicata (Röding, 1798) & 150 \\
\hline & *260. Oliva spicata deynzerae Petuch \& Sargent, 1986 & 137,150 \\
\hline & 261. Olivella cocosensis Olsson, 1956 & 150 \\
\hline \multirow[t]{6}{*}{ Family Ovulidae } & 262. Jenneria pustulata (Lightfoot, 1786) & 150 \\
\hline & 263. Neosimnia aequalis (Sowerby, 1832) & 150 \\
\hline & 264. Neosimnia avena (Sowerby, 1832) & 150 \\
\hline & 265. Pseudocypraea adamsonii (Sowerby, 1832) & 150 \\
\hline & 266. Simnialena rufa (Sowerby, 1832) & 150 \\
\hline & 267. Turbovula lenoreae (Cardin \& Walls, 1980) & 150 \\
\hline Family Pelycidiidae & 268. Pelycidion kelseyi (Bartsch, 1911) & 150 \\
\hline \multirow[t]{3}{*}{ Family Personidae } & 269. Distorsio constricta constricta (Broderip, 1833) & 150 \\
\hline & 270. Distorsio decussata (Valenciennes, 1832) & 150 \\
\hline & 271. Distorsio jenniernestae Emerson \& Piech, 1992 & 150 \\
\hline Family Phenacolepadidae & 272. Plesiothyreus osculans (C.B. Adams, 1852) & 150 \\
\hline Family Phylliroidae & 273. Phyllirö̈ bucephala Péron \& Lesueur,1810 & 130 \\
\hline \multirow[t]{4}{*}{ Family Planaxidae } & 274. Fossarus angulatus Carpenter, 1857 & 150 \\
\hline & 275. Fossarus tuberosus Carpenter, 1857 & 150 \\
\hline & 276. Planaxis planaxis (a) & 98 \\
\hline & 277. Planaxis planicostatus Sowerby, 1825 & 150 \\
\hline \multirow[t]{2}{*}{ Family Pleurobranchidae } & 278. Berthellina ilisima Marcus \& Marcus, 1967 & 38 \\
\hline & 279. Pleurobranchus areolatus (Mörch, 1863) & 38 \\
\hline Family Pneumodermatidae & 280. Pnemodermopsis sp. & 130 \\
\hline Family Polyceridae & 281. Tambja adbere Farmer, 1978 & 38 \\
\hline Family Potamididae & 282. Modulus cerodes (A. Adams, 1851) & 150 \\
\hline Family Pterotracheidae & 283. Pterotrachea coronata Forsskål, 1775 & 130 \\
\hline \multirow[t]{7}{*}{ Family Pyramidellidae } & 284. Herviera gliriella (Melvill \& Standen, 1896) & 150 \\
\hline & 285. Menestho aequisculpta (Carpenter, 1864) & 150 \\
\hline & 286. Menestho grijalvae (Baker, Hanna \& Strong, 1928) & 150 \\
\hline & 287. Miralda armata (Carpenter, 1857) & 150 \\
\hline & 288. Miralda terebellum (C.B. Adams, 1852) & 150 \\
\hline & 289. Triptychus incantatus (Hertlein \& Strong, 1939) & 150 \\
\hline & 290. Turbonilla paucilirata (Carpenter, 1857) & 150 \\
\hline
\end{tabular}




\begin{tabular}{|c|c|c|}
\hline & Species & Ref. $^{1}$ \\
\hline \multirow[t]{9}{*}{ Family Ranellidae } & 291. Charonia tritonis Linnaeus, 1758 & 150 \\
\hline & 292. Cymatium amictum (Reeve, 1844) & 150 \\
\hline & 293. Cymatium aquatile (Reeve, 1844) & 150 \\
\hline & 294. Cymatium cf. keenae & 150 \\
\hline & 295. Cymatium macrodon (Valenciennes, 1832) & 150 \\
\hline & 296. Cymatium muricinum (Röding, 1798) & 150 \\
\hline & 297. Cymatium nicobaricum (Röding, 1798) & 150 \\
\hline & 298. Cymatium succincta (Linnaeus, 1771) & 150 \\
\hline & 299. Cymatium vestitum (Hinds 1844) & 150 \\
\hline Family Retusidae & 300. Volvulella catharia Dall, 1919 & 38 \\
\hline Family Rissoellidae & 301. Rissoella tumens (Carpenter, 1857) & 150,160 \\
\hline \multirow[t]{5}{*}{ Family Rissoidae } & 302. Alvania inconspicua C.B. Adams, 1852 & 150,160 \\
\hline & 303. Folinia ericana (Hertlein \& Strong, 1951) & 150 \\
\hline & 304. Rissoina burragei Bartsch, 1915 & 150 \\
\hline & 305. Rissoina effusa Mörch, 1860 & 150 \\
\hline & 306. Rissoina stricta Menke, 1850 & 150 \\
\hline Family Scissurellidae & 307. Sinezona rimuloides (Carpenter, 1865) & 150 \\
\hline \multirow[t]{2}{*}{ Family Siphonariidae } & 308. Siphonaria gigas Sowerby, 1825 & 60,150 \\
\hline & 309. Williamia $\mathrm{cf}$. peltoides & $60,150,160$ \\
\hline \multirow[t]{2}{*}{ Family Skeneidae } & 310. Parviturbo stearnsii (Dall, 1918) & 150 \\
\hline & 311. Lodderena ornata (Olsson \&McGinty, 1958) & 150 \\
\hline Family Strombidae & 312. Strombus granulatus Swainson, 1822 & 150 \\
\hline \multirow[t]{13}{*}{ Family Terebridae } & 313. Terebra armillata Hinds, 1844 & 150 \\
\hline & 314. Terebra berryi Campbell, 1961 & 150 \\
\hline & 315. Terebra corintoensis Pilsbry \& Lowe, 1932 & 150 \\
\hline & 316. Terebra crenulata (Linnaeus, 1758) & 150 \\
\hline & 317. Terebra elata Hinds, 1844 & 150,160 \\
\hline & 318. Terebra glauca Hinds, 1844 & 150 \\
\hline & 319. Terebra guayaquilensis (E.A. Smith, 1880) & 150 \\
\hline & 320. Terebra hancocki Bratcher \& Burch, 1970 & 150 \\
\hline & 321. Terebra maculata (Linnaeus, 1758) & 150 \\
\hline & 322. Terebra ornata Gray, 1834 & 150 \\
\hline & 323. Terebra robusta Hinds, 1844 & 150 \\
\hline & 324. Terebra strigata Sowerby, 1825 & 150 \\
\hline & 325. Terebra variegata Gray, 1834 & 150 \\
\hline Family Tergipedidae & 326. Phestilla lugubris (Bergh, 1870) & 38 \\
\hline Family Tonnidae & 327. Malea ringens (Swainson, 1822) & 150 \\
\hline \multirow[t]{9}{*}{ Family Triphoridae } & 328. Metaxia brunnicephala (Kay, 1979) & 150 \\
\hline & 329. Metaxia convexa (Carpenter, 1857) & 150 \\
\hline & 330. Triphora alternata C.B. Adams, 1852 & 150 \\
\hline & 331. Triphora chamberlini Baker, 1926 & 150 \\
\hline & 332. Triphora dalli Bartsch, 1907 & 150 \\
\hline & 333. Triphora oweni Baker, 1926 & 150 \\
\hline & 334. Triphora stephensi Baker \& Spicer, 1935 & 150 \\
\hline & 335. Triphora triticea Pease, 1861 & 150 \\
\hline & 336. Viriola samoana Cernohorsky, 1977 & 150 \\
\hline \multirow[t]{2}{*}{ Family Triviidae } & 337. Hespererato oligostata (Dall, 1902) & 150 \\
\hline & 338. Trivia atomaria Dall, 1902 & 150 \\
\hline
\end{tabular}




\begin{tabular}{|c|c|c|}
\hline & Species & Ref. $^{1}$ \\
\hline & 339. Trivia pacifica (Sowerby, 1832, ex Gray, MS) & 150 \\
\hline & 340. Trivia panamensis Dall, 1902 & 150 \\
\hline \multirow[t]{3}{*}{ Family Trochidae } & 341. Calliotropis equatorialis (Dall, 1896) & 150 \\
\hline & 342. Mirachelus galapagensis McLean, 1970 & 150 \\
\hline & 343. Solariella diomedea Dall, 1919 & 150 \\
\hline Family Truncatellidae & 344. Truncatella bairdiana C.B. Adams, 1852 & 150 \\
\hline Family Turbinellidae & 345. Surculina blanda (Dall, 1908) & 150 \\
\hline \multirow[t]{8}{*}{ Family Turbinidae } & 346. Tegula cooksoni (E.A. Smith, 1877) & 150 \\
\hline & 347. Tegula fasciata (Born, 1778) & 150 \\
\hline & 348. Tegula gallina (Forbes, 1850) & 98 \\
\hline & 349. Tegula maculostriata (C.B. Adams, 1845) & 98 \\
\hline & 350. Tricolia diantha (McLean, 1970) as Eulithidium diantha & 150,160 \\
\hline & 351. Tricolia variabilis (Pease, 1861) & 150 \\
\hline & 352. Turbo saxosus Wood, 1828 & 150,160 \\
\hline & 353. Turbo squamiger Reeve, 1843 & 150 \\
\hline \multirow[t]{25}{*}{ Family Turridae } & 354. Agathotoma alcippe (Dall, 1918) & 150 \\
\hline & 355. Bellaspira melea Dall, 1919 & 150 \\
\hline & 356. Buchema granulosa (Sowerby, 1834) & 150 \\
\hline & 357. Clathurella rigida (Hinds, 1843) & 150 \\
\hline & 358. Crassispira abdera (Dall, 1919) & 150 \\
\hline & 359. Crassispira cerithoidea (Carpenter, 1857) & 150 \\
\hline & 360. Crassispira erigone Dall, 1919 & 150 \\
\hline & 361. Crassispira turricula (Sowerby, 1834) & 150 \\
\hline & 362. Daphnella allemani (Bartsch, 1931) & 150 \\
\hline & 363. Daphnella mazatlanica Pilsbry \& Lowe, 1932 & 150 \\
\hline & 364. Daphnella retusa McLean \& Poorman, 1971 & 150 \\
\hline & 365. Glyphostoma neglecta (Hinds, 1843) & 150 \\
\hline & 366. Glyphostoma scobina McLean \& Poorman, 1971 & 150 \\
\hline & 367. Hindsiclava resina (Dall, 1908) & 150 \\
\hline & 368. Iredalea ella (Pilsbry \& Lowe, 1932) & 150 \\
\hline & 369. Iredalea perfecta (Pilsbry \& Lowe, 1932) & 150 \\
\hline & 370. Ithycythara penelope (Dall, 1919) & 150 \\
\hline & 371. Kurtziella plumbea (Hinds, 1843) & 150 \\
\hline & 372. Microdaphne trichodes (Dall, 1919) & 150 \\
\hline & 373. Microdrillia zeuxippe (Dall, 1919) & 150 \\
\hline & 374. Mitromorpha filosa (Carpenter, 1865) & 150 \\
\hline & 375. Nannodiella nana (Dall, 1919) & 150 \\
\hline & 376. Tenaturris merita (Hinds, 1843) & 150 \\
\hline & 377. Xanthodaphne agonia (Dall, 1890) & 150 \\
\hline & 378. Xanthodaphne encella (Dall, 1908) & 150 \\
\hline \multirow[t]{3}{*}{ Family Turritellidae } & 379. Turritella clarionensis (Hertlein \& Strong, 1951) & 150 \\
\hline & 380. Vermicularia cf. frisbeyae & 150 \\
\hline & 381. Vermicularia pellucida eburnea (Reeve, 1842) & 150 \\
\hline \multirow[t]{2}{*}{ Family Vanikoridae } & 382. Vanikoro acuta Récluz, 1844 & 150 \\
\hline & 383. Vanikoro aperta (Carpenter, 1864) & 150 \\
\hline \multirow[t]{4}{*}{ Family Vermetidae } & 384. Eualetes tulipa (Chenu, 1843, ex Rousseau, MS) & 150 \\
\hline & 385. Petaloconchus complicatus Dall, 1908 & 150 \\
\hline & 386. Petaloconchus macrophragma (Carpenter, 1856) & 150 \\
\hline & 387. Vermetus sp. & 98 \\
\hline
\end{tabular}


Family Vitrinellidae
Class BIVALVIA, Order ANOMALODESMATA
Family Poromyidae

Order ARCoIDA, Family Arcidae

Family Glycymerididae

Family Noetiidae

Order MytiLoIDA, Family Mytilidae

Order PterIOIDA, Family Isognomonidae

Family Malleidae

Family Pinnidae

Family Pteriidae

Order Limoida, Family Limidae

Order OstreoIdA, Family Anomiidae

Family Gryphaeidae

Family Ostreidae

Family Pectinidae

392. Cetomya scapha (Dall, 1902) as Cetoconcha scapha 98

393. Acar gradata (Broderip \& Sowerby, 1829) 118

394. Anadara (Esmerarca) reinharti (Lowe, 1935) 118

395. Anadara (Grandiarca) grandis 118

(Broderip \& Sowerby, 1829)

396. Arca (Arca) mutabilis (Sowerby, 1833) 118

397. Arca (Arca) pacifica (Sowerby, 1833) 118

398. Barbatia (Cucullaearca) reeveana (d'Orbigny, 1846) 118

399. Larkinia multicostata (Sowerby, 1833)

400. Axinactis inaequalis (Sowerby, 1833) 70

401. Glycymeris (Glycymeris) gigantea (Reeve, 1843) 118

402. Glycymeris (Glycymeris) lintea Olsson, 1961

403. Glycymeris (Tucetona) strigilata (Sowerby, 1833) 118

404. Arcopsis solida (Sowerby, 1833) 118

405. Crenella decussata (Montagu, 1808) 118

406. Crenella divaricata (Orbigny in Sagra, 1853) 98

407. Lithophaga (Diberus) plumula (Hanley, 1843) 118

408. Lithophaga (Labis) attenuata (Deshayes, 1836) 98

409. Lithophaga (Myoforceps) aristata (Dillwyn, 1817) 118

410. Lithophaga (Stumpiella) calyculata (Carpenter, 1857) 118

411. Septifer zeteki Hertlein \& Strong, 1946

412. Isognomon bicolor (Adams, 1845) as I. chmnitzianum 98

413. Isognomon (Melina) janus Carpenter, $1857 \quad 118,160$

414. Isognomon (Melina) recognitus (Mabille, 1895) $\quad 118,160$

415. Isognomon quadrangularis (a) 98

416. Malleus (Malvufundus) regulus (Forsskål, 1775) 118

417. Atrina (Servatrina) tuberculosa (Sowerby, 1835) 118

418. Steptopinna saccata (Linnaeus, 1758) 118

419. Pincatada mazatlanica (Hanley, 1856) 69

420. Pteria sterna (Gould, 1851) 118

421. Lima tetrica Gould, 1851

422. Limaria pacifica (d'Orbigny, 1846) 118

423. Anomia (Anomia) peruviana d'Orbigny, $1846 \quad 118$

424. Hyotissa solida (Sowerby, 1871) 118

425. Crassostrea palmula (Carpenter, 1857) 118

426. Crassostrea prismatica (Gray, 1825) 118

427. Dendostrea folium (Linnaeus, 1758) 118

428. Argopecten circularis (Sowerby, 1835) 70

429. Euvola galapagensis (Grau, 1959) 118

430. Euvola hancocki (Grau, 1959) 89

431. Envola perulus (Olsson, 1961) 118

432. Euvola vogdesi (Arnold, 1906) 118

*433. Leopecten cocosensis Waller, 2007 


Family Propeamussiidae
Family Spondylidae
Order VENERoIDA, Family Cardiidae
Family Carditidae
Family Chamidae
Family Condylocardiidae
Family Lasaeidae
Family Lucinidae

Family Neoleptonidae

Family Semelidae

Family Tellinidae

Family Ungulinidae

Family Veneridae

Order MyoidA, Family Corbulidae

Family Thraciidae

Order Septibranchida, Family Verticordiidae

Class CEPHALOPODA, Order OCTOPODA, Family Octopodidae

Undefined generic placement

Order OEgoPsidA, Family Argonautidae

Family Cranchiidae
Species

434. Leopecten sericeus (Hinds, 1845)

435. Nodipecten subnodosus (Sowerby, 1853)

436. Cyclopecten cocosensis (Dall, 1908)

437. Cyclopecten exquisitus Grau, 1959

438. Spondylus calcifer Carpenter, 1857

439. Spondylus limbatus Sowerby, 1847

440. Spondylus linguaefelis Sowerby, $1847 \quad 118$

441. Spondylus violacescens Lamarck, 1819 as S. tenebrosus 69

442. Papyridea aspersa (Sowerby, 1833) 118

443. Americardia planicostata (Sowerby, 1833) 118

444. Cardites laticostata (Sowerby, 1833) 118

445. Strophocardia megastropha (Gray, 1825) 118

446. Chama squamuligera Pilsbry \& Lowe, 1932

447. Pseudochama clarionensis Willett, 1938

448. Condylocardia hippopus (Mörch, 1861) 118

449. Amerycina colpoica (Dall, 1913) 118

450. Solecardia eburnea Conrad, $1849 \quad 118$

451. Codakia distinguenda (Tryon, 1872) 118

452. Ctena clarionensis Hertlein \& Strong, 1946

453. Divalinga eburnea (Reeve, 1850) 118

454. Divalinga perparvula (Dall, 1901) 118

455. Neolepton (Neolepton) subtrigonum (Carpenter, 1857) 118

456. Semele (Amphidesma) formosa (Sowerby, 1833) 118

457. Semele (Amphidesma) purpurascens (Gmelin, 1791) 118

458. Semele (Elegantula) rupium (Sowerby, 1833) 118

459. Semele jamesi Coan, $1988 \quad 118$

460. Tellina (Elliptotellina) pacifica Dall, 1900

461. Tellina (Laciolina) ochracea Carpenter, 1864

462. Tellina (Moerella) coani Keen, 1971

463. Tellina (Tellinella) cumingii Hanley, 1844

464. Diplodonta subquadrata Carpenter, 1856 as $\quad 70$

D. (Diplodonta) subquadrata

465. Globivenus isocardia (Verrill, 1870) 118

466. Pitar (Hyphantosoma) hertleini Olsson, 1961

467. Corbula (Caryocorbula) nasuta Sowerby, $1833 \quad 118$

468. Bushia galapagana (Dall, 1915) 118

469. Haliris aequacostata (Howard, 1950) 118

470. Muusoctopus januarii (Hoyle, 1885) as Polypus januarii 102

471. Octopus pusillus Gould, 1852 as Polypus pusellus 102

472. "Octopus" alecto Berry, 1953

473. Argonauta argo Linnaeus, $1758 \quad 102$

474. Argonauta cornutus Conrad, 1854

475. Argonauta nouryi Lorois, 1852

476. Argonauta pacifica Dall, 1871

477. Galiteuthis pacifica (Robson, 1948) as 98

Taonidium pacificum

478. Helicocranchia beebei Robson, $1948 \quad 98$

479. Liocranchia reinhardti (Steenstrup, 1856) 98 


Family Enoploteuthidae
Family Octopoteuthidae
Family Ommastrephidae
Family Onychoteuthidae
Family Thysanoteuthidae
Order TeUTHIDA, Family Loliginidae
Order VAMPYROMORPHA, Family Vampyroteuthidae
Phylum SIPUNCULA, Class
PHASCOLOSOMATIDEA
Order ASPIDOSIPHONIFORMES,
Family Aspidosiphonidae

Class PHASCOLOSOMATIDEA, Order

Phascolosomatiformes, Family Phascolosomatidae

Class SIPUNCULIDEA, Order SiPunCULIFoRmEs, Family Sipunculidae

Phylum ECHIURIDA, CLASS ECHIUROIDEA Order EchIURIDA, Family Echiuridae

Phylum ANNELIDA, Class POLYCHAETA, Subclass ACICULATA, Order AMPHINOMIDA, Suborder Aphroditiformia, Family Amphinomidae

Family Chrysopetalidae

Family Pisionidae

Subclass ACICULATA, Order EunICIDA,

Family Dorvilleidae

Family Eunicidae
Species

480. Pterygioteuthis giardi hoylei (Pfeffer, 1912) as Pyroteuthis giardi

481. Octopoteuthis neilseni Robson, 1948

98

482. Abraliopsis hoylei (Pfeffer, 1884)

483. Dosidicus gigas (Orbigny, 1835)

484. Ommastrephes bartrami (LeSueur, 1821)

485. Sthenoteuthis oualaniensis (Lesson, 1830)

486. Onychoteuthis banksi (Leach, 1817)

487. Onykia sp.

488. Thysanoteuthis rhombus Troschel, 1857

489. Lolliguncula (Loliolopsis) diomedeae (Hoyle, 1904)

490. Vampyroteuthis infernalis Chun, 1903 as Melanoteuthis beebei

1. Aspidosiphon elegans Chimisso \& Eysenhardt, 1821

2. Aspidosiphon gracilis schnehageni (W. Fischer, 1913) 65

3. Aspidosiphon misakiensis Ikeda, 1904

4. Aspidosiphon (Paraspidosiphon) laevis de 65 Quatrefages 1865

5. Aspidosiphon (Paraspidosiphon) fischeri ten Broeke, 1925

65

6. Antillesoma antillarum (Grube \& Oersted 1858) 65

7. Phascolosoma agassizii Keferstein, $\mathbf{1 8 6 6} 65$

8. Phascolosoma nigrescens (Keferstein, 1865) 65

9. Phascolosoma scolops Selenka and de Man, $1883 \quad 65$

10. Phascolosoma sp.

11. Sipunculus norvegicus Danielssen 1869

1. Thalassema steinbecki Fisher, 1946

$\begin{array}{ll}\text { 1. Chloeia entypa Chamberlin, } 1919 & 63,67\end{array}$

2. Chloeia cf. pinnata Moore, 1911

3. Chloeia viridis Schmarda, $1861 \quad 63,67$

4. Eurythoe complanata (Pallas, 1776) 63,67

5. Linopherus canariensis Langerhans, 1881

6. Notopygos crinita Grube, 1855

7. Notopygos ornata Grube, $1856 \quad 67,160$

8. Pareurythoe paupera (Grube, 1856) 67

9. Pareurythoe spirocirrata (Essenberg, 1917) 67

10. Chrysopetalum occidentale Johnson, 1897

11. Pisione cf. galapagoensis Westheide, 1974

12. Dorvillea (Dorvillea) cerasina (Ehlers, 1901) $\quad 67,160$

13. Eunice aphroditois (Pallas, 1788) 67

14. Eunice biannulata Moore, 1904 


\begin{tabular}{|c|c|c|}
\hline & Species & Ref. $^{1}$ \\
\hline & 15. Eunice mutilata Webster, 1884 & 67 \\
\hline & 16. Lysidice sp. & 67 \\
\hline & 17. Nematonereis unicornis (Grube, 1840) & 67,160 \\
\hline & 18. Palola cf. siciliensis (Grube, 1840) & 67 \\
\hline \multirow[t]{2}{*}{ Family Lumbrineridae } & 19. Lumbrineris annulata Hartmann-Schröder, 1960 & 67 \\
\hline & 20. Scoletoma tetraura (Schmarda, 1861) & 67 \\
\hline \multirow[t]{3}{*}{ Family Oenonidae } & 21. Arabella (Arabella) protomutans Orensanz, 1990 & 67 \\
\hline & 22. Drilonereis longa Webster, 1879 & 67 \\
\hline & 23. Oenone fulgida (Savigny in Lamarck, 1818) & 67 \\
\hline Family Onuphidae & 24. Mooreonuphis elsiae de León-González, 1994 & 67 \\
\hline $\begin{array}{l}\text { Subclass ACICULATA, Order PHYLlOdocida, } \\
\text { Suborder Aphroditiformis, Family Acoetidae }\end{array}$ & 25. Polyodontes panamensis Chamberlin, 1919 & 67 \\
\hline \multirow[t]{8}{*}{ Family Polynoidae } & 26. Harmothoe imbricata (Linnaeus, 1767) & 67 \\
\hline & 27. Harmothoe sp. & 67,160 \\
\hline & 28. Iphione ovata Kinberg, 1855 & $64,67,160$ \\
\hline & 29. Lepidasthenia gigas (Johnson, 1897) & 67 \\
\hline & 30. Lepidasthenia ornata Treadwell, 1937 & 67 \\
\hline & 31. Lepidasthenia picta Treadwell, 1928 & 67 \\
\hline & 32. Lepidonotus furcillatus (Ehlers, 1901) & 98 \\
\hline & 33. Subadyte cf. mexicana Fauchald, 1972 & 67 \\
\hline \multirow[t]{4}{*}{ Family Sigalionidae } & 34. Psammolyce spinosa Hartman, 1939 & 63 \\
\hline & 35. Sigalion lewisii Berkely \& Berkely, 1939 & 63,67 \\
\hline & $\begin{array}{l}\text { 36. Sigalion spinosus (Hartman, 1939) as } \\
\text { Eusigalion spinosus }\end{array}$ & 92 \\
\hline & 37. Sthenelais fusca Johnson, 1897 & 98 \\
\hline \multirow[t]{4}{*}{$\begin{array}{l}\text { Subclass ACICULATA, Order Phyllodocida, } \\
\text { Suborder Nereidiformia, Family Hesionidae }\end{array}$} & 38. Hesione $\mathrm{cf}$. intertexta Grube, 1878 & 67,160 \\
\hline & 39. Microphthalmus indefatigatus Westheide, 1974 & 67 \\
\hline & 40. Podarkeopsis brevipalpa Hartmann-Schröder, 1959 & 67 \\
\hline & 41. Psamathe ancuda (Wesenberg-Lund, 1962) & 67 \\
\hline \multirow[t]{9}{*}{ Family Nereididae } & 42. Ceratonereis singularis Treadwell, 1929 & 67,160 \\
\hline & 43. Laeonereis brunnea Hartmann-Schröder, 1959 & 67 \\
\hline & 44. Neanthes acuminata Ehlers, 1868 & 67 \\
\hline & 45. Neanthes cf. roosevelti Hartman, 1939 & 67 \\
\hline & 46. Neanthes succinea (Frey \& Leuckart, 1847) & 67 \\
\hline & 47. Nereis eugeniae (Kinberg, 1866) & 67 \\
\hline & 48. Nereis oligohalina (Rioja, 1946) & 67 \\
\hline & 49. Nereis panamensis Fauchald, 1977 & 67 \\
\hline & 50. Perinereis helleri (Grube, 1878) & 63,103 \\
\hline Family Pilargidae & 51. Synelmis gorgonensis (Monro, 1933) & 67 \\
\hline \multirow[t]{8}{*}{ Family Syllidae } & 52. Branchiosyllis exilis (Gravier, 1900) & 67 \\
\hline & 53. Branchiosyllis sp. Grube, 1857 & 67 \\
\hline & 54. Eusyllis lamelligera Marion \& Bobretzky, 1875 & 67 \\
\hline & $\begin{array}{l}\text { 55. Exogone (Exogone) breviantennata } \\
\text { Hartmann-Schröder, } 1959\end{array}$ & 67,160 \\
\hline & 56. Myrianida multidenticulata (Westheide, 1974) & 67 \\
\hline & 57. Odontosyllis fulgurans dolerus Westheide, 1974 & 67,160 \\
\hline & 58. Opisthodonta mitchelli Kudenov \& Harris, 1995 & 67 \\
\hline & 59. Opisthodonta sp. & 67 \\
\hline
\end{tabular}


Subclass ACICULATA, Order Phyllodocida,

Family Alciopidae

Family Glyceridae

Family Lopadorrhynchidae

Family Phyllodocidae

Family Polynoidae

Family Tomopteridae

Family Typhloscolecidae

Subclass CANALIPALPATA, Order Sabellida, Family Sabellariidae

Family Sabellidae

Family Serpulidae

Subclass CANALIPALPATA, Order SPIONIDA, Family Chaetopteridae

Family Magelonidae

Family Spionidae
Species

Ref. ${ }^{1}$

60. Opisthosyllis brunnea Langerhans, 1879

67

61. Paraehlersia articulata (Kudenov \& Harris 1995)

67,160

62. Syllis bella Chamberlin, 1919

63. Syllis beneliahuae (Campoy \& Alquezar, 1982)

64. Syllis garciai (Campoy, 1982)

65. Syllis gracilis Grube, 1840

66. Syllis cf. hyalina Grube, 1863

67. Syllis magna (Westheide, 1974)

68. Syllis valida (Grube, 1857)

67,160

69. Syllis variegata (Grube, 1860) as $S$. variagata

70. Trypanosyllis taeniaeformis (Haswell, 1886)

67,160

71. Westheidesyllis heterocirrata (Hartmann-Schröder, 1959)

72. Alciopina parasitica Claparède \& Panceri, 1867

106

73. Glycera brevicirris Grube, 1870

74. Hemipodia pustatula (Friedrich, 1956)

75. Pelagobia longicirrata Gravier, 1911

67,160

106

76. Nereiphylla castanea (Marzeneller, 1879)

67,160

77. Phyllodoce madeirensis Langerhans, 1880

67,160

78. Phyllodoce medipapillata Moore, 1909

79. Sige cf. bifoliata (Moore, 1909)

80. Drieschia pellucida Moore, 1903

67,160

106

106

63

106

106

84. Typhloscolex muelleri Busch, 1851

67

85. Gesaia sp.

67

86. Bispira melanostigma Schmarda, 1861

$67,160,170$ Tovar-Hernández \& Dean, 2010

88. Megalomma pacifica Johansson, 1927

89. Vermiliopsis multiannulata (Moore, 1923)

67,160

90. Chaetopterus aduncus Nishi, Hickman \& Baily-Brock, 2009

91. Chaetopterus $\mathrm{cf}$. galapagenis Nishi, Hickman \& Bailey-Brock, 2009

92. Chaetopterus sp.

93. Mesochaetopterus alipes Monro, 1933

94. Mesochaetopterus ecuadorica (Nishi, 2009)

95. Spiochaetopterus costarum (Claparéde, 1870)

96. Magelona californica Hartman, 1944

97. Aonides cf. glandulosa Blake, 1996

98. Aonides paucibranchiata Southern, 1914

99. Laonice cirrata (Sars, 1851)

100. Microspio microcera (Dorsey, 1977)

101. Prionospio (Prionospio) sp.

102. Rhynchospio glutaea (Ehlers, 1897) 


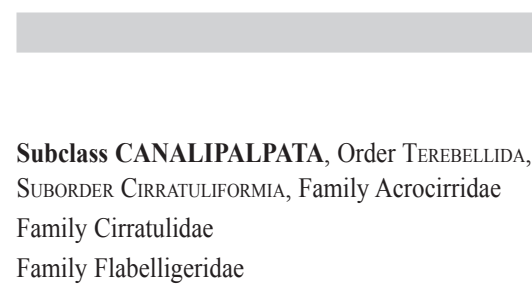

Subclass CANALIPALPATA, Order Terebellida, Suborder Terebellomorpha, Family Ampharetidae Family Terebellidae

Family Trichobranchidae

Subclass SCOLECIDA (no assigned Order), Family Capitellidae

Family Opheliidae

Family Orbiniidae

Family Paraonidae

Polychaeta incertae sedis, Family Protodrilidae

Phylum ARTHROPODA, Subphylum CRUSTACEA

Class MALACOSTRACA, Order Stomatopoda

Family Coronididae

Family Gonodactylidae

Family Pseudosquillidae

Family Squillidae

Family Tetrasquillidae

Order Euphausiacea, Family Euphausiidae

Order DECAPODA, Family Aethridae

Family Albuneidae

Family Alpheidae

Family Atyidae

Family Benthesicymidae

\section{Species}

103. Scolelepis (Scolelepis) squamata (Müller, 1806)

104. Spiophanes berkeleyorum Pettibone, 1962

105. Acrocirrus heterochaetus Annenkova, 1934

106. Dodecaceria sp.

107. Pherusa inflata (Treadwell, 1914)

108. Pherusa papillata (Johnson, 1901)

109. Unidentified species

110. Lanice conchilega (Pallas, 1766)

111. Polycirrus mexicanus Rioja, 1947

112. Polycirrus sp.

113. Trichobranchus hancocki (Hartman, 1955)

\section{7}

114. Notodasus kristiani García-Garaz, Hernández-Valdez \& de León-González, 2009

115. Notomastus lineatus Claparéde, 1870

\section{7}

67

67

67

116. Armandia brevis (Moore, 1906)

67,160

117. Naineris chilensis (Hartmann-Schröder, 1965)

118. Naineris setosa (Verrill, 1900)

119. Aricidea (Aricidea) rosea Reish, 1968 as A. (Acesta) rosea

120. Protodrilus infundibuliformis Schmidt \& Westheide, 1977

1. Coronida schmitti Manning, 1976

2. Neocoronida cocosiana (Manning, 1972)

3. Neogonodactylus zacae (Manning, 1972)

4. Pseudosquillisma adiastalta Manning, 1964

5. Crenatosquilla oculinova (Glassell, 1942)

6. Tetrasquilla mccullochae (Schmitt, 1940)

7. Several unidentified species

8. Aethra scutata Smith, 1869

9. Albunea lucacia (de Saussure, 1853)

10. Alpheus bellimanus Lockington, 1877

11. Alpheus canalis Kim \& Abele, 1988

12. Alpheus galapagensis Sivertsen, 1933

13. Alpheus grahami Abele, 1975

14. Alpheus hebes Kim \& Abele, 1988

177, 178

15. Alpheus longiquus Kim \& Abele, 1988

177, 178

16. Alpheus lottini Guérin-Méneville, 1829

177,178

17. Alpheus pacificus Dana, 1852

177,178

18. Alpheus saxidomus Holthuis, 1980

177,178

19. Alpheus villus Kim \& Abele, 1988

177,178

20. Automate dolichognatha Dellan, 1888

177, 178

21. Synalpheus sp.

177,178

22. Archaeatya chacei Villalobos, 1959

23. Benthesicymus tanneri Faxon, 1893 


\begin{tabular}{|c|c|c|}
\hline & Species & Ref. $^{1}$ \\
\hline \multirow[t]{4}{*}{ Family Calappidae } & 24. Calappa convexa Saussure, 1853 & 177,178 \\
\hline & 25. Calappa saussurei Rathbun, 1898 & 177,178 \\
\hline & 26. Cryptosoma bairdii Rathbun, 1898 & 177,178 \\
\hline & 27. Osachila kaiserae Zimmerman \& Martin, 1999 & 177,178 \\
\hline Family Coenobitidae & 28. Coenobita compressus Milne Edwards, 1837 & 177 \\
\hline Family Crangonidae & 29. Pontophillus gracilis occidentales Faxon, 1893 & 177 \\
\hline Family Daldorfiidae & 30. Daldorfia garthi Glassell, 1940 & 177 \\
\hline \multirow[t]{5}{*}{ Family Diogenidae } & *31. Allodardanus rugosus Haig \& Provenzano, 1965 & 177,178 \\
\hline & 32. Calcinus explorator Boone, 1930 & 177,178 \\
\hline & *33. Cancellus tanneri Faxon, 1893 & 177,178 \\
\hline & 34. Dardanus sinistripes (Stimpson, 1859) & 177,178 \\
\hline & *35. Paguristes fecundus Faxon, 1893 & 177,178 \\
\hline \multirow[t]{2}{*}{ Family Dorippidae } & 36. Ethusa lata Rathbun, 1893 & 177,178 \\
\hline & 37. Ethusina smithiana Faxon, 1893 & 177,178 \\
\hline Family Dromiidae & 38. Hipoconcha panamensis Smith, 1869 & 177 \\
\hline Family Dynomenidae & 39. Dynomene ursula Stimpson, 1860 & 178 \\
\hline \multirow[t]{2}{*}{ Family Gecarcinidae } & 40. Cardisoma crassum Smith, 1870 & 85 \\
\hline & *41. Johngarthia cocoensis Perger, Vargas \& Wall, 2011 & 136 \\
\hline \multirow[t]{5}{*}{ Family Grapsidae } & 42. Armases angustum (Smith, 1870) & 177,178 \\
\hline & 43. Geograpsus lividus (Milne Edwards, 1837) & 177,178 \\
\hline & 44. Grapsus grapsus (Linnaeus, 1758) & 177,178 \\
\hline & 45. Pachygrapsus transversus (Gibbes, 1850) & 177,178 \\
\hline & 46. Plagusia immaculata Lamarck, 1818 & 177,178 \\
\hline Family Hippidae & 47. Hippa pacifica (Dana, 1852) & 178 \\
\hline \multirow[t]{3}{*}{ Family Hippolytidae } & 48. Lysmata galapagensis Schmitt, 1924 & 177,178 \\
\hline & 49. Thor amboinensis (De Man, 1888) & $\begin{array}{c}160,177 \\
178\end{array}$ \\
\hline & 50. Thor cocoensis Wicksten \& Vargas, 2001 & 177,178 \\
\hline Family Leucosiidae & 51. Ebalia clarionensis Rathbun, 1935 & 178 \\
\hline \multirow[t]{2}{*}{ Family Lithodidae } & 52. Neolithodes diomedeae (Benedict, 1894) & 177,178 \\
\hline & 53. Ericerodes longipes Faxon, 1893 as $P$. longipes & 177,178 \\
\hline \multirow[t]{12}{*}{ Family Majidae } & 54. Euprognatha bifida Rathbun, 1893 & 177,178 \\
\hline & 55. Euprognatha granulata Faxon, 1893 & 177,178 \\
\hline & 56. Herbstia tumida (Stimpson, 1871) & $\begin{array}{c}160,177 \\
178\end{array}$ \\
\hline & 57. Lissa tuberosa Rathbun, 1898 & 177,178 \\
\hline & 58. Microphrys branchialis Rathbun, 1892 & 177,178 \\
\hline & 59. Mithrax denticulatus Bell, 1835 & 177,178 \\
\hline & 60. Mithrax spinipes (Bell, 1835) & 177,178 \\
\hline & $\begin{array}{l}\text { 61. Ericerodes hemphilli (Lockington, 1877) as } \\
\text { Podochela hemphilli }\end{array}$ & 177,178 \\
\hline & 62. Sphenocarcinus agassizi Rathbun, 1893 & 177,178 \\
\hline & 63. Stenocionops ovata (Bell, 1835) & 177,178 \\
\hline & 64. Stenorhynchus debilis (Smith, 1871) & 177,178 \\
\hline & 65. Teleophrys cristulipes Stimpson, 1860 & $\begin{array}{c}160,177 \\
178\end{array}$ \\
\hline \multirow[t]{2}{*}{ Family Munididae } & 66. Munida perlata Benedict, 1902 & 177,178 \\
\hline & 67. Munida refulgens Faxon, 1893 & 177,178 \\
\hline
\end{tabular}




\begin{tabular}{|c|c|c|}
\hline & Species & Ref. $^{1}$ \\
\hline \multirow[t]{5}{*}{ Family Munidopsidae } & 68. Munidopsis aspera (Henderson, 1885) & 177,178 \\
\hline & 69. Munidopsis ciliata Wood-Mason, 1891 & 177,178 \\
\hline & 70. Munidopsis diomedeae (Faxon, 1893) & 177,178 \\
\hline & 71. Munidopsis nitida (A. Milne Edwards, 1880) & 177,178 \\
\hline & 72. Munidopsis vicina Faxon, 1893 & 177,178 \\
\hline \multirow[t]{2}{*}{ Family Nematocarcinidae } & 73. Nematocarcinus agassizzi Faxon 1893 & 177 \\
\hline & 74. Nematocarcinus ensifer (Smith, 1882) & 177 \\
\hline \multirow[t]{4}{*}{ Family Ocypodidae } & 75. Ocypode gaudichaudii Milne Edwards \& Lucas, 1843 & 177,178 \\
\hline & 76. Uca brevifrons (Stimpson, 1860) & 177,178 \\
\hline & 77. Uca panamensis (Stimpson, 1859) & 177,178 \\
\hline & 78. Uca zacae Crane, 1941 & 53 \\
\hline Family Oplophoridae & 79. Meningodora mollis Smith, 1882 & 178 \\
\hline \multirow[t]{7}{*}{ Family Paguridae } & 80. Catapagurus diomedeae Faxon, 1893 & 177,178 \\
\hline & *81. Enallopaguropsis janetae McLaughlin, 1982 & 177,178 \\
\hline & 82. Iridopagurus occidentalis Faxon, 1893 & 177,178 \\
\hline & 83. Manucomplanus longimanus (Faxon, 1893) & 177,178 \\
\hline & 84. Pagurus virgulatus Haig \& Harvey, 1991 & 177,178 \\
\hline & 85. Phimochirus californiensis (Benedict, 1892) & 177,178 \\
\hline & 86. Rhodochirus hirtimanus (Faxon, 1893) & 177,178 \\
\hline \multirow[t]{6}{*}{ Family Palaemonidae } & 87. Brachycarpus biunguiculatus (Lucas, 1849) & 177,178 \\
\hline & 88. Harpiliopsis depressa (Stimpson, 1860) & 177,178 \\
\hline & 89. Macrobrachium americanum Bate, 1868 & 177,178 \\
\hline & *90. Macrobrachium cocoensis Abele \& Kim, 1984 & 1,177 \\
\hline & 91. Macrobrachium hancocki Holthuis, 1952 & 177,178 \\
\hline & 92. Palaemon ritteri Holmes, 1895 & 177,178 \\
\hline Family Palicidae & 93. Palicus fragilis Rathbun, 1893 & 177 \\
\hline \multirow[t]{2}{*}{ Family Palinuridae } & 94. Panulirus gracilis Streets, 1871 & 177,178 \\
\hline & 95. Panulirus penicillatus Olivier, 1791 & 177,178 \\
\hline Family Pandalidae & 96. Heterocarpus hostilis Faxon 1893 & 178 \\
\hline Family Parapaguridae & 97. Probeebei mirabilis Boone, 1926 & 178 \\
\hline \multirow[t]{5}{*}{ Family Parthenopidae } & 98. Celatopesia hassleri (Rathbun, 1925) & 177,178 \\
\hline & 99. Parthenope exilipes (Rathbun, 1893) & 177,178 \\
\hline & 100. Solenolambrus arcuatus Stimpson, 1871 & 177,178 \\
\hline & $\begin{array}{l}\text { 101. Thyrolambrus verrucibrachium Zimmerman \& } \\
\text { Martin, } 1999\end{array}$ & 177,178 \\
\hline & 102. Thyrolambrus glasselli Garth, 1958 & 177,178 \\
\hline \multirow[t]{3}{*}{ Family Penaeidae } & 103. Pelagopenaeus balboae (Faxon, 1893) & 177,178 \\
\hline & 104. Hymenopenaeus doris (Faxon, 1893) & 177,178 \\
\hline & 105. Hymenopenaeus nereus (Faxon, 1893) & 177,178 \\
\hline \multirow[t]{2}{*}{ Family Pinnotheridae } & *106. Parapinnixa cortesi Thoma, Heard \& Vargas, 2005 & 169,177 \\
\hline & 107. Tetrias scabripes Rathbun, 1918 & 177 \\
\hline Family Polychelidae & 108. Stereomastis nana (Smith, 1884) & 178 \\
\hline \multirow[t]{7}{*}{ Family Porcellanidae } & 109. Pachycheles biocellatus (Lockington, 1878) & 177,178 \\
\hline & 110. Pachycheles velerae Haig, 1960 & 177,178 \\
\hline & *111. Petrolisthes cocoensis Haig, 1960 & $88,177,178$ \\
\hline & 112. Petrolisthes edwardsii (de Saussure, 1853) & 177,178 \\
\hline & 113. Petrolisthes glasselli Haig, 1957 & 177,178 \\
\hline & 114. Petrolisthes haigae Chace, 1962 & 177,178 \\
\hline & 115. Petrolisthes ortmanni Nobili, 1901 & 177,178 \\
\hline
\end{tabular}




\begin{tabular}{|c|c|c|}
\hline & Species & Ref. $^{1}$ \\
\hline & 116. Petrolisthes tonsorius Haig, 1960 & 177,178 \\
\hline & 117. Porcellana cancrisocialis Glassell, 1936 & 177,178 \\
\hline & 118. Porcellana paguriconviva Glassell, 1936 & 177,178 \\
\hline \multirow[t]{5}{*}{ Family Portunidae } & 119. Arenaeus mexicanus (Gerstaecker, 1856) & 177,178 \\
\hline & 120. Callinectes arcuatus Ordway, 1863 & 177,178 \\
\hline & 121. Euphylax dovii Stimpson, 1860 & 177,178 \\
\hline & 122. Portunus brevimanus (Faxon, 1895) & 177,178 \\
\hline & 123. Portunus xantussi affinis (Faxon, 1893) & 177,178 \\
\hline Family Processidae & 124. Processa peruviana Wicksten, 1983 & 178 \\
\hline Family Raninidae & 125. Ranilia fornicata Faxon, 1893 & 178 \\
\hline \multirow[t]{2}{*}{ Family Sicyoniidae } & 126. Sicyonia affinis Faxon, 1893 & 177,178 \\
\hline & 127. Sicyonia disedwardsi (Burkenroad, 1934) & 177,178 \\
\hline \multirow[t]{2}{*}{ Family Solenoceridae } & 128. Hymenopenaeus doris (Faxon, 1893) & 177 \\
\hline & 129. Hymenopenaeus nereus (Faxon, 1893) & 177 \\
\hline Family Upogebiidae & *130. Pomatogebia cocosia (Williams, 1986) & 178,184 \\
\hline \multirow[t]{16}{*}{ Family Xanthidae } & 131. Cycloxanthops vittatus (Stimpson, 1860) & 177,178 \\
\hline & 132. Domencia hispida Eydoux \& Souleyet, 1842 & 177,178 \\
\hline & 133. Eriphia squamata Stimpson, 1859 & 177,178 \\
\hline & 134. Liomera cinctimana (White, 1847) & 177,178 \\
\hline & 135. Lophoxanthus lamellipes (Stimpson, 1860) & 177,178 \\
\hline & 136. Microcassiope xantusii (Stimpson, 1871) & 177,178 \\
\hline & 137. Nanocassiope polita (Rathbun, 1893) & 177,178 \\
\hline & 138. Ozius perlatus Stimpson, 1860 & 177,178 \\
\hline & 139. Paractaea sulcata (Stimpson, 1860) & $160,177,178$ \\
\hline & 140. Pilumnus gonzalensis Rathbun, 1893 & 177,178 \\
\hline & 141. Platyactaea dovii (Stimpson, 1871) & 177,178 \\
\hline & 142. Quadrella nitida Smith, 1869 & 177,178 \\
\hline & 143. Trapezia digitalis Latreille, 1828 & 177,178 \\
\hline & 144. Trapezia ferruginea Latreille, 1828 & 177,178 \\
\hline & 145. Xanthodius sternberghii Stimpson, 1859 & 177,178 \\
\hline & 146. Xanthodius stimpsoni (Milne Edwards, 1879) & 177,178 \\
\hline Order IsOPODA, Family Argidae & 147. Aega plebia Hansen, 1897 & 26 \\
\hline Family Cirolanidae & 148. Eurydice caudata Richardson, 1899 & 25,26 \\
\hline Family Cymothoidae & 149. Nerocila excisa (Richardson, 1901) & 26 \\
\hline Order MysidA, Family Mysidae & 150. Several unidentified species & 130 \\
\hline Order Tanaidacea, Family Leptocheliidae & 151. ?Anatanais & 96 \\
\hline Order AMPHIPODA, Family Aoridae & 152. Lembos schire Barnard, 1979 & 11 \\
\hline Family Brachyscelidae & 153. Brachyscelus crusculum Bate, 1861 & 87 \\
\hline Family Isaeidae & *154. Gammaropsis dubia (Shoemaker, 1942) & 79 \\
\hline \multirow[t]{8}{*}{ Family Lestrigonidae } & 155. Hyperietta vosseleri (Stebbing, 1904) & 87 \\
\hline & 156. Hyperioides sibaginis (Stebbing, 1888) & 87 \\
\hline & 157. Lestrigonus bengalensis Giles, 1887 & 87 \\
\hline & 158. Lestrigonus latissimus (Bovallius, 1889) & 87 \\
\hline & 159. Lestrigonus macrophthalmus (Vosseler, 1901) & 87 \\
\hline & 160. Lestrigonus schizogeneios (Stebbing, 1888) & 87 \\
\hline & 161. Lestrigonus shoemakeri Bowman, 1973 & 87 \\
\hline & 162. Phronimopsis spinifera Claus, 1879 & 87 \\
\hline Family Lycaeidae & 163. Simorhynchotus antennarius (Claus, 1871) & 87 \\
\hline
\end{tabular}




\begin{tabular}{|c|c|c|}
\hline & Species & Ref. $^{1}$ \\
\hline \multirow[t]{2}{*}{ Family Lycaepsoidae } & 164. Lycaeopsis themistoides Claus, 1879 & 87 \\
\hline & 165. Lycaeopsis zamboangae (Stebbing, 1888) & 87 \\
\hline Family Oxycephalidae & 166. Oxycephalus clausi Bovallius, 1887 & 87 \\
\hline Family Paraphronimidae & 167. Paraphronima gracilis Claus, 1879 & 87 \\
\hline Family Parascelidae & 168. Parascelus edwardsi Claus, 1879 & 87 \\
\hline Family Phronimidae & 169. Phronima bowmani Shih, 1991 & 87 \\
\hline \multirow[t]{2}{*}{ Family Phrosinidae } & 170. Phrosina semilunata Risso, 1822 & 87 \\
\hline & 171. Primno brevidens Bowman, 1978 & 87 \\
\hline \multirow[t]{2}{*}{ Family Platyscelidae } & 172. Amphithyrus sculpturatus Claus, 1879 & 87 \\
\hline & 173. Tetrathyrus forcipatus Claus, 1879 & 87 \\
\hline Family Pronoidae & 174. Eupronoe armata Claus, 1879 & 87 \\
\hline Family Talitridae & *175. Talorchestia fritzi Stebbing, 1903 & 79 \\
\hline Family Vibiliidae & 176. Vibilia chuni Behning \& Woltereck, 1912 & 87 \\
\hline \multicolumn{3}{|l|}{ Class CIRRIPEDIA, Order LEPADOMORPHA } \\
\hline \multirow[t]{3}{*}{ Family Lepadidae } & 177. Conchoderma virgata (Spengler, 1790) & 173 \\
\hline & 178. Lepas anatifera Linnaeus, 1758 & 173 \\
\hline & 179. Lepas anserifera Linnaeus, 1767 & 173 \\
\hline \multirow[t]{3}{*}{ Order BalanomorPha, Family Balanidae } & 180. Arossia panamensis (Rogers, 1948) & 173 \\
\hline & 181. Megabalanus galapaganus Pilsbry, 1916 & 173 \\
\hline & 182. Megabalanus peninsularis (Pilsbry, 1916) & 173 \\
\hline Family Chthamalidae & 183. Chthamalus cf. anisopoma & 173 \\
\hline \multirow[t]{5}{*}{ Family Coronulidae } & 184. Chelonibia testudinaria (Linnaeus, 1757) & 173 \\
\hline & 185. Coronula diadema Darwin, 1854 & 173 \\
\hline & 186. Coronula reginae Darwin, 1854 & 173 \\
\hline & 187. Stomatolepas elegans (Costa, 1838) & 173 \\
\hline & 188. Xenobalanus globicipitis Steenstrup, 1851 & 173 \\
\hline \multirow[t]{2}{*}{ Family Tetraclitidae } & 189. Tetraclita milleporosa Pilsbry, 1916 & 173 \\
\hline & 190. Tetraclita stalactifera (Lamarck, 1818) & 173 \\
\hline Order Calanoida, Family Calanidae & 191-196. Six species & 130 \\
\hline Family Calocalanidae & 197. One species & 130 \\
\hline Family Centropagidae & 198-201. Four species & 130 \\
\hline Family Clausocalanidae & 202. Clausocalanus furcatus (Brady, 1883) & 130 \\
\hline \multirow[t]{3}{*}{ Family Eucalanidae } & 203. Rhincalanus nasutus Giesbrecht, 1888 & 130 \\
\hline & 204. Subeucalanus subtenuis (Giesbrecht, 1888) & 130 \\
\hline & 205, 206. Plus two more species & 130 \\
\hline Family Euchaetidae & 207. Euchaeta rimana Bradford, 1974 & 130 \\
\hline Family Mecynoceridae & 208. One species & 130 \\
\hline Family Metridinidae & 209. One species & 130 \\
\hline \multirow[t]{3}{*}{ Family Paracalanidae } & 210. Acrocalanus gracilis Giesbrecht, 1888 & 130 \\
\hline & 211. Paracalanus aculeatus Giesbrecht, 1888 & 130 \\
\hline & 212, 213. Plus two more species & 130 \\
\hline Family Phaennidae & 214. One species & 130 \\
\hline \multirow[t]{2}{*}{ Family Pontellidae } & 215. Labidocera detruncata (Dana, 1849) & 130 \\
\hline & 216-218. Plus three more species & 130 \\
\hline Family Scolecithricidae & 219. Scolecthrix danae Lubbock, 1856 & 130 \\
\hline \multirow[t]{2}{*}{ Order Monstrilloida, Family Monstrillidae } & $\begin{array}{l}\text { *220. Cymbasoma cocoense Suárez-Morales \& } \\
\text { Morales-Ramírez, } 2009\end{array}$ & 167 \\
\hline & $\begin{array}{l}\text { *221. Monstrillopsis chathamensis Suárez-Morales \& } \\
\text { Morales-Ramírez, } 2009\end{array}$ & 167 \\
\hline
\end{tabular}




\begin{tabular}{|c|c|c|}
\hline & Species & Ref. $^{1}$ \\
\hline Order Poecilostomatoida, Family Corycaeidae & 222-231. Ten species & 130 \\
\hline Family Oncaeidae & 232. Oncaea mediterranea (Claus, 1883) & 130 \\
\hline Family Sapphirinidae & 233-242. Ten species & 130 \\
\hline Order Siphonostomatoida, Family Caligidae & 243. Lepeophtheirus sp. (see note (b) below) & 165 \\
\hline Other copepods & 244-260. Seventeen more species in 5 families & 130 \\
\hline \multicolumn{3}{|l|}{ Class BRANCHIOPODA, Order Cladocera } \\
\hline Family Podonidae & 261. Evadne sp. & 130 \\
\hline \multicolumn{3}{|l|}{ Class OSTRACODA, Order MyodocopidA } \\
\hline Family Cypridinidae & 262. Cypridina americana (Muller, 1880) & 130 \\
\hline Family Halocyprididae & 263. Euchoncoecia sp. & 130 \\
\hline \multicolumn{3}{|l|}{$\begin{array}{l}\text { Subphylum CHELICERATA, Class } \\
\text { PYCNOGONIDA }\end{array}$} \\
\hline Order Pantopoda, Family Ammotheidae & $\begin{array}{l}\text { 264. Ammothella symbius Child, } 1979 \\
\text { 265. Tanystylum isthmiacum Stock, } 1955\end{array}$ & $\begin{array}{l}9 \\
9\end{array}$ \\
\hline \multicolumn{2}{|l|}{ Subphylum HEXAPODA, Class INSECTA } & 162 \\
\hline \multicolumn{3}{|l|}{ Phylum CHAETOGNATHA, Class } \\
\hline Order ApHaragmophora, Family Krohnittidae & 1. Krohnitta pacifica (Aida, 1897) & 41 \\
\hline Family Pterosagittidae & 2. Pterosagitta draco (Krohn, 1853) & 41 \\
\hline \multirow[t]{6}{*}{ Family Sagittidae } & 3. Aidanosagitta neglecta (Aida, 1897) & 41 \\
\hline & 4. Ferosagitta robusta (Doncaster, 1902) & 41 \\
\hline & 5. Flaccisagtita enflata (Grassi, 1881) & 41,130 \\
\hline & 6. Serratosagitta pacifica (Tokioka, 1940) & 41,130 \\
\hline & 7. Zonosagitta bedoti (Beraneck, 1895) & 41 \\
\hline & 8. Zonosagitta pulchra (Doncaster, 1902) & 41 \\
\hline \multicolumn{3}{|l|}{ Phylum BRYOZOA, Class STENOLAEMATA } \\
\hline Order Cүсlostomata, Family Oncousoeciidae & 1. Proboscina major (Johnston, 1847) & 135 \\
\hline \multicolumn{3}{|l|}{ Class GYMNOLAEMATA, Order Cheilostomata } \\
\hline Family Adeonidae & $\begin{array}{l}\text { 2. Reptadeonella violacea (Johnston, 1847) as } \\
\text { Adeona violacea }\end{array}$ & 51,134 \\
\hline Family Bryocryptellidae & 3. Porella patens Osburn, 1952 & 51,134 \\
\hline Family Buffonellodidae & 4. Aimulosia uvulifera (Osburn, 1914) & $51,134,160$ \\
\hline Family Bugulidae & 5. Bugula minima (Waters, 1909) & 51,133 \\
\hline \multirow[t]{4}{*}{ Family Calloporidae } & 6. Aplousina filum (Jullien \& Calvet, 1903) & 51,133 \\
\hline & 7. Retevirgula areolata (Canu \& Bassler, 1923) & 98 \\
\hline & 8. Copidozoum tenuirostre (Hincks, 1880) & 98 \\
\hline & 9. Parellisina curvirostris (Hincks, 1862) & 98 \\
\hline Family Candidae & 10. Scrupocellaria bertholettii tenuirostris Osburn, 1950 & 133 \\
\hline Family Cellariidae & 11. Cellaria veleronis Osburn, 1950 & 98 \\
\hline Family Celleporidae & 12. Lagenipora marginata (Canu \& Bassler, 1930) & 51,134 \\
\hline Family Chaperiidae & $\begin{array}{l}\text { 13. Chaperiopsis condylata (Canu \& Bassler, 1930) as } \\
\text { Chaperiella condylata }\end{array}$ & 98 \\
\hline Family Cleidochasmatidae & 14. Cleidochasma contracta (Waters, 1899) & 98 \\
\hline \multirow[t]{2}{*}{ Family Crepidacanthidae } & 15. Crepidacantha poissoni (Audouin, 1826) & 98 \\
\hline & 16. Crepidacantha setigera (Smitt, 1873) & 51,134 \\
\hline Family Cribrilinidae & 17. Colletosia radiata Moll, 1803) & 98 \\
\hline Family Cupuladriidae & 18. Discoporella umbellata (Defrance, 1823) & 98,160 \\
\hline Family Exechonellidae & $\begin{array}{l}\text { 19. Triporula manica (Canu \& Bassler, 1930) as } \\
\text { Enantiosula manica }\end{array}$ & 51,134 \\
\hline
\end{tabular}




\begin{tabular}{|c|c|c|}
\hline & Species & Ref. $^{1}$ \\
\hline Family Hippothoidae & 20. Trypostega venusta (Norman, 1864) & 51,134 \\
\hline \multirow[t]{2}{*}{ Family Lacernidae } & 21. Arthropoma cecili (Audouin, 1826) & 51,134 \\
\hline & 22. Rogicka biserialis (Hincks, 1885) as Dakaria biserialis & 134 \\
\hline Family Lepraliellidae & $\begin{array}{l}\text { 23. Celleporaria brunnea (Hincks, 1884) as } \\
\text { Holoporella brunnea }\end{array}$ & 98 \\
\hline Family Mamilloporidae & 24. Mamillopora cupula Smitt, 1873 & 51,134 \\
\hline \multirow[t]{2}{*}{ Family Microporellidae } & 25. Microporella ciliata (Pallas, 1766) & 98 \\
\hline & 26. Microporella marsupiata (Busk, 1860) & 98 \\
\hline Family Microporidae & 27. Micropora coriacea inarmata Soule, 1959 & 98 \\
\hline Family Phidoloporidae & 28. Reteporellina denticulata var. gracilis (Busk, 1884) & 51,134 \\
\hline Family Schizoporellidae & 29. Hippodiplosia insculpta (Hincks), 1882 & 134 \\
\hline Family Tubuliporidae & 30. Tubulipora flexuosa (Pourtales, 1867) & 98 \\
\hline Family Watersiporidae & 31. Watersipora biserialis (Hincks, 1885) & 49 \\
\hline \multicolumn{3}{|l|}{$\begin{array}{l}\text { Phylum BRACHIOPODA, } \\
\text { Class RHYNCHONELLATA }\end{array}$} \\
\hline Order Rhynchonellida, Family Basiliolidae & 1. Neorhynchia strebeli (Dall, 1908) & 71 \\
\hline Family Frieleiidae & $\begin{array}{l}\text { *2. Abyssirhynchia craneana (Dall, 1895) as } \\
\text { Hispanirhynchia? craneana }\end{array}$ & 59,98 \\
\hline \multirow[t]{2}{*}{ Order Terebratulida, Family Terebratulidae } & $\begin{array}{l}\text { 3. Gryphus clarkeana (Dall, 1920) as } \\
\text { Liothyrella clarkeana }\end{array}$ & 71 \\
\hline & 4. Liothyrella moseleyi (Davidson, 1878) & 71 \\
\hline \multirow[t]{2}{*}{ Family Zeilleriidae } & 5. Macandrevia americana Dall, 1895 as M. craniella & 71 \\
\hline & 6. Macandrevia diamantina (Dall, 1895) & 71 \\
\hline Phylum PHORONIDA & 1. Phoronopsis albomaculata Gilchrist, 1907 & 66 \\
\hline \multicolumn{3}{|l|}{$\begin{array}{l}\text { Phylum ECHINODERMATA, Class } \\
\text { CRINOIDEA }\end{array}$} \\
\hline Order Comatulida, Family Antedonidae & 1. Fariometra parvula (Hartlaub, 1895) & 7 \\
\hline Family Thalassometridae & 2. Thalassometra agassizii (Hartlaub, 1895) & 7 \\
\hline \multicolumn{3}{|l|}{ Class ASTERoIDEA, Order PAXILLOSIDA } \\
\hline \multirow[t]{4}{*}{ Family Astropectinidae } & *3. Astropecten benthophilus Ludwig, 1905 & 7 \\
\hline & 4. Astropecten sulcatus Ludwig, 1905 & 7 \\
\hline & 5. Leptychaster inermis (Ludwig, 1905) & 7 \\
\hline & *6. Persephonaster armiger Ludwig, 1905 & 7 \\
\hline Family Luidiidae & 7. Luidia armata Ludwig, 1905 & 7 \\
\hline \multirow[t]{2}{*}{ Family Porcellanasteridae } & 8. Eremicaster pacificus (Ludwig, 1905) & 7 \\
\hline & 9. Porcellanaster ceruleus Wyville-Thomson, 1877 & 7 \\
\hline \multirow[t]{2}{*}{ Order NотомүотіDA, Family Bentopectinidae } & $\begin{array}{l}\text { 10. Benthopecten spinuliger (Ludwig, 1905) as } \\
\text { Parachaster spinuliger }\end{array}$ & 7,159 \\
\hline & 11. Pectinaster agassizii Ludwig, 1905 & 7 \\
\hline Order ValVATIDA, Family Acanthasteridae & 12. Acanthaster planci (Linnaeus, 1758) also as $\boldsymbol{A}$. ellisii & $5,6,7,159$ \\
\hline Family Asterodiscididae & 13. Paulia horrida Gray, 1840 as Pauliella aenigma & 7,119 \\
\hline Family Asteropseidae & 14. Asteropsis carinifera (Lamarck, 1816) & 6,159 \\
\hline \multirow[t]{3}{*}{ Family Goniasteridae } & 15. Mediaster elegans Ludwig, 1905 & 7 \\
\hline & 16. Nymphaster diomedeae Ludwig, 1905 & 7 \\
\hline & 17. Pillsburiaster ernesti (Ludwig, 1905) & 7 \\
\hline Family Mithrodiidae & 18. Mithrodia bradleyi Verrill, 1867 & 5,6 \\
\hline \multirow[t]{4}{*}{ Family Ophidiasteridae } & 19. Linckia columbiae Gray, 1840 & $5,6,7$ \\
\hline & 20. Narcissia gracilis A.H. Clark, 1916 & 5,7 \\
\hline & 21. Phataria unifascialis (Gray, 1840) as Phataria sp. & $5,7,159$ \\
\hline & 22. Tamaria obstipa Ziesenhenne, 1942 & $5,7,159$ \\
\hline
\end{tabular}


Family Oreasteridae

Order Forcipulatida, Family Asteriidae

Order BrisingIDA, Family Brisingidae

Class OPHIUROIDEA, Order PhrynophIURIDA

Family Ophiomyxidae

Order OphIURIDA, Family Amphiuridae

Family Hemieurylidae

Family Ophiactidae

Family Ophiocanthidae

Family Ophiocomidae

Family Ophiodermatidae

Family Ophionereidae

Family Ophiotrichidae

Family Ophiuridae
23. Nidorellia armata (Gray, 1840)

24. Pentaceraster cumingi (Gray, 1840) as Oreaster occidentales

25. Hymenaster quadrispinosus Fisher, 1905 as H. purpureus

26. Pteraster cf. diaphanous (Ludwig, 1905)

27. Coronaster marchenus Ziesenhenne, 1942

28. Hydrasterias improvisus (Ludwig, 1905) as H. improvisa and as Pedicellaster improvisus

29. Sclerasterias alexandri (Ludwig, 1905)

30. Sclerasteias heteropaes Fisher, 1924

31. Tarsaster cocosanus (Ludwig, 1905)

32. Astrolirus panamensis (Ludwig, 1905)

33. Ophiomyxa panamensis Lütken \& Mortensen, 1899

34. Amphiodia tabogae Nielsen, 1932

35. Amphiodia violacea (Lütken, 1856)

36. Amphiura arcystata H.L. Clark, 1911

37. Ophiophragmus marginatus (Lütken, 1859)

38. Ophiophragmus paucispinus Nielsen, 1932

39. Triplodia abdita A.M. Clark, 1970 as Triodia abdita

40. Sigsbeia lineata Lütken \& Mortensen, 1899

41. Ophiactis savignyi (Müller \& Troschel, 1842)

42. Ophiactis simplex (Le Conte, 1851)

43. Ophiocantha phragma Ziesenhenne, 1940

44. Ophiotoma paucispina (Lütken \& Mortensen, 1899)

45. Ophiocoma aethiops Lütken, 1859

46. Ophiocoma alexandri Lyman, 1860

47. Ophiocomella sexradia (Duncan, 1887)

48. Diopederma danianum (Verrill, 1867)

49. Ophiocrytus granulosus Nielsen, 1932

50. Ophioderma panamense Lütken, 1859

51. Ophioderma variegatum Lütken, 1856

52. Ophionereis albomaculata E.A. Smith, 1877 as O. nuda

53. Ophionereis annulata (Le Conte, 1851)

54. Ophionereis eurybrachiplax H.L. Clark, 1911

55. Ophiothrix spiculata Le Conte, 1851

56. Amphiophiura abcisa (Lütken \& Mortensen, 1899)

57. Ophiocten hastatum Lyman, 1878

58. Ophiomusium glabrum Lütken \& Mortensen, 1899 as Ophiosphalma glabrum

59. Ophiomusium lymani Thomson, 1873

60. Ophiozonella alba (Lütken \& Mortensen, 1899)

61. Ophiura nana (Lütken \& Mortensen, 1899)

62. Ophiura (Ophiuroglypha) irrorata (Lyman, 1878)

63. Centrocidaris doederleini (A. Agassiz, 1898)

64. Eucidaris thouarsii (Valenciennes, 1846)

65. Eucidaris thouarsii galapagensis Döderlein, 1887 as E. galapagensis

\section{Ref. ${ }^{1}$}

$5,6,7$

$5,6,7,42$,

7,159

5,7

7, 159

5,7

7

7

7

5,7

5, 7

5, 7, 159

5,7

5, 7

5, 7

5,7

5,7

$5,7,160$

5,7

5, 7

7

$5,6,7$

$5,6,7$

5, 7

5, 7

5,7

5,7

5,7

5, 7, 159

5,7

5,7

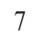

5,7

5, 7, 159

5,7

5, 7

5, 7

5,7

5, 7

5, 7

5, 7

5, 7, 159

Family Cidaridae 


\begin{tabular}{|c|c|c|}
\hline & Species & Ref. $^{1}$ \\
\hline & $\begin{array}{l}\text { 66. Hesperocidaris dubia (H.L. Clark, 1907) as } \\
\text { Stylocidaris dubia }\end{array}$ & $5,7,159$ \\
\hline & 67. Hesperocidaris panamensis (A. Agassiz, 1898) & 5,7 \\
\hline Order EchinothurioIDA, Family Echinothuriidae & 68. Tromikosoma hispidum (A. Agassiz, 1898) & 5,7 \\
\hline Order Diadematoida, Family Aspidodiadematidae & 69. Plesiodiadema horridum (A. Agassiz, 1898) & 5,7 \\
\hline \multirow[t]{5}{*}{ Family Diadematidae } & 70. Astropyga pulvinata (Lamarck, 1816) & 159 \\
\hline & 71. Centrostephanus coronatus (Verrill, 1867) & 5,7 \\
\hline & 72. Diadema mexicanum A. Agassiz, 1863 & $5,6,7,160$ \\
\hline & 73. Echinothrix calamaris (Pallas, 1774) & $5,6,7$ \\
\hline & 74. Echinothrix diadema (Linnaeus, 1758) & $5,6,7,113$ \\
\hline Order SALENIOIDA, Family Saleniidae & 75. Salenocidaris miliaris (A. Agassiz, 1898) & 5,7 \\
\hline \multirow[t]{3}{*}{ Order Temnopleuroida, Family Toxopneustidae } & 76. Lytechinus pictus (Verrill, 1867) & 5,7 \\
\hline & 77. Toxopneustes roseus (A. Agassiz, 1863) & $5,6,7$ \\
\hline & 78. Tripneustes depressus A. Agassiz, 1863 & $5,6,7$ \\
\hline \multirow[t]{2}{*}{ Order EchINOIDA, Family Echinometridae } & 79. Echinometra oblonga (Blainville, 1825) & $5,6,7$ \\
\hline & 80. Echinometra vanbrunti A. Agassiz, 1863 & $5,6,7$ \\
\hline \multirow[t]{4}{*}{ Order Clypeasteroida, Family Clypeasteridae } & 81. Clypeaster europacificus H.L. Clark, 1914 & $5,7,159$ \\
\hline & 82. Clypeaster ochrus H.L. Clark, 1914 & $5,7,159$ \\
\hline & 83. Clypeaster rotundus (A. Agassiz, 1863) & 5,7 \\
\hline & 84. Clypeaster speciosus Verrill, 1870 & 5,7 \\
\hline \multirow[t]{2}{*}{ Family Mellitidae } & *85. Encope cocosi H.L. Clark, 1948 & 5,7 \\
\hline & 86. Encope micropora L. Agassiz, 1841 & 5,7 \\
\hline Order SpaTANGOIDA, Family Aeropsidae & 87. Aeropsis fulva (A. Agassiz, 1898) & 5,7 \\
\hline Family Asterostomatidae & 88. Argopatagus aculeata (Agassiz, 1898) & 5,7 \\
\hline \multirow[t]{3}{*}{ Family Brissidae } & 89. Brissopsis pacifica (A. Agassiz, 1898) & $5,7,159$ \\
\hline & 90. Meoma ventricosa grandis Gray, 1851 & $5,7,159$ \\
\hline & $\begin{array}{l}\text { 91. Rhabdobrissus pacificus H.L. Clark, } 1940 \text { as } \\
\text { Plagiobrissus pacificus }\end{array}$ & $5,7,159$ \\
\hline \multirow[t]{2}{*}{ Family Loveniidae } & 92. Homolampas hastata A. Agassiz, 1879 & 5,7 \\
\hline & 93. Lovenia cordiformis A. Agassiz, 1872 & 5,7 \\
\hline \multicolumn{3}{|l|}{$\begin{array}{l}\text { Class HOLOTHUROIDEA, } \\
\text { Order DENDROCHIROTIDA }\end{array}$} \\
\hline \multirow[t]{2}{*}{ Family Psolidae } & 94. Lissothuria ornata Verrill, 1867 as Thyonepsolus beebi & $5,7,159$ \\
\hline & 95. Psolus diomedeae Ludwig, 1894 & 5,7 \\
\hline Family Cucumariidae & 96. Abyssocucumis abyssorum (Théel, 1886) & 159 \\
\hline Order DactyLосніRотіDA, Family Ypsilothuriidae & 97. Ypsilothuria bitentaculata (Ludwig, 1893) & 5,7 \\
\hline \multirow[t]{11}{*}{ Order Aspidochirotida, Family Holothuriidae } & $\begin{array}{l}\text { 98. Holothuria (Cystipus) casoae Laguarda-Figueras \& } \\
\text { Solís-Marín, } 2009\end{array}$ & 110 \\
\hline & 99. Holothuria (Cystipus) inhabilis Selenka, 1867 & 5,7 \\
\hline & 100. Holothuria (Halodeima) atra (Jaeger, 1833) & $5,6,7$ \\
\hline & 101. Holothuria (Halodeima) kefersteini (Selenka, 1867) & $5,6,7$ \\
\hline & 102. Holothuria (Lessonothuria) pardalis Selenka, 1867 & 5,7 \\
\hline & $\begin{array}{l}\text { 103. Holothuria (Mertensiothuria) fuscocinerea } \\
\text { (Jaeger, 1833) }\end{array}$ & 5,7 \\
\hline & 104. Holothuria (Mertensiothuri) hilla Lesson, 1830 & $5,6,7,159$ \\
\hline & $\begin{array}{l}\text { 105. Holothuria (Mertensiothuria) leucospilota } \\
\text { (Brandt, 1835) }\end{array}$ & 5,7 \\
\hline & 106. Holothuria (Platyperona) difficilis Semper, 1868 & $5,7,159$ \\
\hline & 107. Holothuria (Selenkothuria) theeli (Deichmann, 1938) & 5,7 \\
\hline & 108. Holothuria (Semperothuria) imitans Ludwig, 1875 & 5,7 \\
\hline
\end{tabular}




\begin{tabular}{|c|c|c|}
\hline & Species & Ref. $^{1}$ \\
\hline & $\begin{array}{l}\text { 109. Holothuria (Theelothuria) paraprinceps } \\
\text { Deichmann, } 1937\end{array}$ & 5,7 \\
\hline & 110. Holothuria (Thymiosycia) arenicola Semper, 1868 & 5,7 \\
\hline & 111. Holothuria (Thymiosycia) impatiens (Forskål, 1775) & 5,7 \\
\hline & 112. Labidodemas americanum Deichmann, 1938 & 5,7 \\
\hline \multirow[t]{2}{*}{ Family Stichopodidae } & 113. Isostichopus fuscus (Ludwig, 1875) & $5,6,7$ \\
\hline & 114. Stichopus horrens Selenka, 1867 & $5,6,7$ \\
\hline \multirow[t]{3}{*}{ Family Synallactidae } & $\begin{array}{l}\text { 115. Mesothuria (Mesothuria) multipes Ludwig, } 1894 \text { as } \\
\text { M. multiples }\end{array}$ & $5,7,159$ \\
\hline & 116. Pseudostichopus macdonaldi (Ludwig, 1894) & 5,7 \\
\hline & 117. Pseudostichopus mollis Théel, 1886 & 5,7 \\
\hline Order APODIDA, Family Chiridotidae & 118. Chiridota pacifica Heding, 1928 & 5,7 \\
\hline Order Elasipodida, Family Deimatidae & 119. Deima validum pacificum Ludwig, 1894 & 5,7 \\
\hline Family Elpidiidae & 120. Peniagone vitrea Théel, 1882 & 5,7 \\
\hline Family Pelagothuridae & 121. Pelagothuria natatrix Ludwig, 1894 & 5,7 \\
\hline Family Psychropotidae & 122. Benthodytes sanguinolenta Théel, 1882 & 5,7 \\
\hline Order MOLPADIDA, Family Molpadidae & 123. Molpadia musculus Risso, 1826 & 159 \\
\hline \multicolumn{3}{|l|}{$\begin{array}{l}\text { Phylum CHORDATA, } \\
\text { Class APPENDICULARIA }\end{array}$} \\
\hline \multirow[t]{7}{*}{ Family Oikopleuridae } & 1. Oikopleura cophocerca (Gegenbaur, 1855) & 41 \\
\hline & 2. Oikopleura dioica Fol, 1872 & 41 \\
\hline & 3. Oikopleura fusiformis Fol, 1872 & 41,130 \\
\hline & 4. Oikopleura gracilis (Lohmann, 1896) & 41 \\
\hline & 5. Oikopleura longicauda (Vogt, 1854) & 41 \\
\hline & 6. Oikopleura rufescens Fol, 1872 & 41,130 \\
\hline & 7. Stegosoma magnum (Langerhans, 1880) & 41 \\
\hline \multirow[t]{2}{*}{ Family Fritillariidae } & $\begin{array}{l}\text { 8. Fritillaria formica } \\
\text { (Lohmann in Lohmann \& Büchmann, 1926) }\end{array}$ & 41 \\
\hline & 9. Fritillaria haplostoma (Fol, 1872; emend. Fol, 1874) & 41 \\
\hline \multicolumn{3}{|l|}{ Class THALIACEA, Order SALPIDA } \\
\hline \multirow[t]{2}{*}{ Family Salpidae } & 10. Salpa sp. & 130 \\
\hline & 11. Doliolum sp. & 130 \\
\hline Orden PYROSOMATIDA & 12. One species & 130 \\
\hline \multicolumn{3}{|l|}{ Class LEPTOCARDII, } \\
\hline Family Branchiostomidae & 13. Asymmetron lucayanum Andrews, 1893 & 158 \\
\hline \multicolumn{3}{|l|}{ Class ELASMOBRANCHII } \\
\hline \multirow[t]{10}{*}{ Family Carcharhinidae } & 14. Carcharhinus albimarginatus (Rüppell, 1837) & 34,35 \\
\hline & 15. Carcharhinus falciformis (Müller \& Henle, 1839) & $34,35,163$ \\
\hline & 16. Carcharhinus galapagensis (Snodgrass \& Heller, 1905) & 34,35 \\
\hline & 17. Carcharhinus limbatus (Muller \& Henle, 1839) & 34,35 \\
\hline & 18. Carcharhinus longimanus (Poey, 1861) & 143 \\
\hline & 19. Carcharhinus melanopterus (Quoy \& Gaimard, 1824) & 116 \\
\hline & 20. Galeocerdo cuvier (Peron \& Lesueur en Lesueur, 1822) & 34,35 \\
\hline & 21. Prionace glauca (Linnaeus, 1758) & 142 \\
\hline & 22. Rhizoprionodon longurio (Jordan \& Gilbert, 1882) & 34,35 \\
\hline & 23. Triaenodon obesus (Rüppell, 1837) & 34,35 \\
\hline Family Lamnidae & 24. Carcharodon carcharias (Linnaeus, 1758) & 35 \\
\hline Family Sphyrnidae & 25. Sphyrna lewini (Griffith \& Smith, 1834) & $34,35,163$ \\
\hline
\end{tabular}




\begin{tabular}{|c|c|c|}
\hline & Species & Ref. $^{1}$ \\
\hline & 26. Sphyrna mokarran (Rüppell, 1837) & 34,35 \\
\hline & 27. Sphyrna tiburo (Linnaeus, 1758) & 142 \\
\hline Order ChIMAERIFormes, Family Chimaeridae & 28. Hydrolagus sp. & 122 \\
\hline Order LAMnIFormes, Family Alopiidae & 29. Alopias vulpinus (Bonnaterre, 1788) & 35 \\
\hline Family Lamnidae & 30. Isurus oxyrinchus Rafinesque, 1810 & 142 \\
\hline Family Odontaspididae & 31. Odontaspis ferox (Risso, 1810) & 47,52 \\
\hline Family Pseudocarchariidae & 32. Pseudocarcharias kamoharai (Matsubara, 1936) & 142 \\
\hline Order Orectolobiformes, Family Rhincodontidae & 33. Rhincodon typus Smith, 1828 & 35,52 \\
\hline \multirow[t]{3}{*}{ Order RAJIFORMES, Family Dasyatidae } & 34. Dasyatis sp. & 52 \\
\hline & 35. Pteroplatytrygon violacea (Bonaparte, 1832) & 142 \\
\hline & 36. Taeniura meyeni Muller \& Henle, 1841 & 35,52 \\
\hline \multirow[t]{4}{*}{ Family Mobulidae } & 37. Manta birostris (Walbaum, 1792) & $34,35,52$ \\
\hline & 38. Mobula japanica (Müller \& Henle, 1841) & 142 \\
\hline & 39. Mobula munkiana Notabartolo di Sciara, 1987 & 34,35 \\
\hline & 40. Mobula tarapacana (Philippi, 1893) & $35,52,163$ \\
\hline \multirow[t]{3}{*}{ Family Myliobatidae } & 41. Aetobatus narinari (Euphrasen, 1790) & $34,35,52$ \\
\hline & 42. Myliobatis peruvianus Garman, 1913 & 122 \\
\hline & 43. Rhinoptera steindachneri Evermann \& Jenkins, 1892 & 34,35 \\
\hline \multirow[t]{2}{*}{ Family Rajidae } & 44. Bathyraja spinosissima (Beebe \& Tee-Van, 1941) & 122 \\
\hline & 45. Raja equatorialis Jordan \& Bollman, 1890 & 142 \\
\hline Family Rhinobatidae & 46. Rhinobatos planiceps Garman, 1880 & 34,35 \\
\hline Order SQUALIFormes, Family Echinorhinidae & 47. Echinorhinus cookei Pietschmann, 1928 & $\begin{array}{c}35,47,52 \\
115,122\end{array}$ \\
\hline Order Torpediniformes, Family Torpedinidae & 48. Torpedo peruana Chirichigno, 1963 & 52 \\
\hline \multicolumn{3}{|l|}{ Class ACTINOPTERYGII, Order ANGUILLIFORMES } \\
\hline \multirow[t]{5}{*}{ Family Congridae } & 49. Ariosoma gilberti (Ogilby, 1898) & 34,35 \\
\hline & 50. Bathycongrus varidens (Garman, 1899) & 163 \\
\hline & $\begin{array}{l}\text { 51. Heteroconger klausewitzi } \\
\text { (Eibl-Eibesfeldt \& Köster, 1983) }\end{array}$ & $34,35,122$ \\
\hline & 52. Ophisoma sp. & 122 \\
\hline & 53. Paraconger californiensis Kanazawa, 1961 & 34,35 \\
\hline \multirow[t]{17}{*}{ Family Muraenidae } & 54. Anarchias galapagensis (Seale, 1940) & 34,35 \\
\hline & 55. Echidna nebulosa (Ahl, 1789) & $3,34,35$ \\
\hline & 56. Echidna nocturna (Cope, 1872) & 34,35 \\
\hline & 57. Enchelycore octaviana (Myers \& Wade, 1941) & 34,35 \\
\hline & 58. Gymnomuraena zebra (Shaw, 1797) & 34,35 \\
\hline & $\begin{array}{l}\text { 59. Gymnothorax angusticeps } \\
\text { (Hildebrand \& Barton, 1949) }\end{array}$ & 122 \\
\hline & 60. Gymnothorax buroensis (Bleeker, 1857) & 34,35 \\
\hline & 61. Gymnothorax castaneus (Jordan \& Gilbert, 1883) & 34,35 \\
\hline & 62. Gymnothorax dovii (Günther, 1870) & 34,35 \\
\hline & 63. Gymnothorax eurostus (Abbott, 1860) & 140 \\
\hline & 64. Gymnothorax flavimarginatus (Rüppell, 1830) & 34,35 \\
\hline & 65. Gymnothorax javanicus (Bleeker, 1859) & 34,35 \\
\hline & 66. Gymnothorax meleagris (Shaw \& Nodder, 1795) & 34,35 \\
\hline & 67. Gymnothorax panamensis (Steindachner, 1876) & 34,35 \\
\hline & 68. Gymnothorax pictus (Ahl, 1789) & 84 \\
\hline & 69. Muraena argus (Steindachner, 1870) & 34,35 \\
\hline & 70. Muraena clepsydra Gilbert, 1898 & 34,35 \\
\hline
\end{tabular}




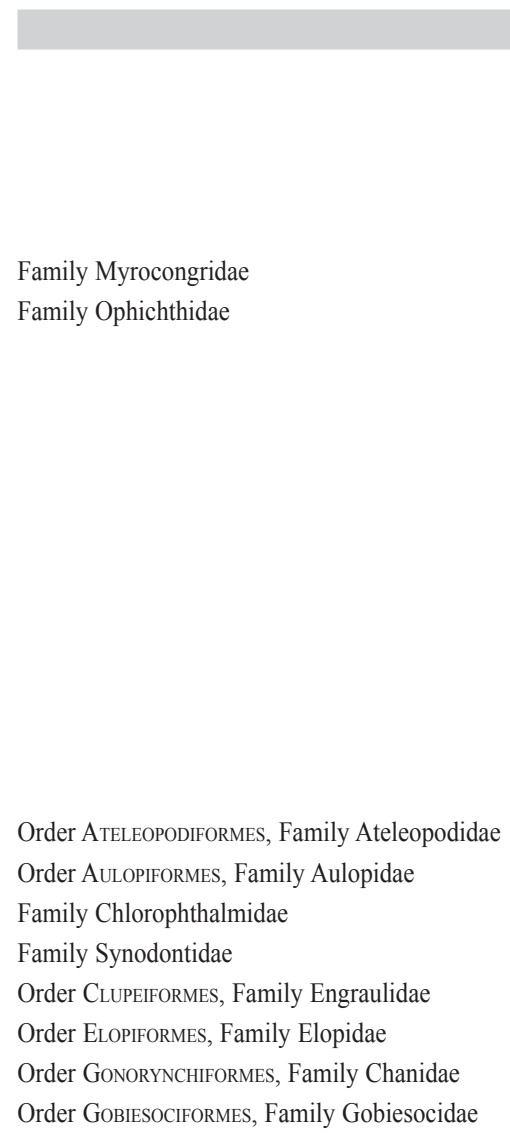

Order LoPHIIFORMES, Family Antennariidae

Family Lophiidae

Family Ogcocephalidae

Order Gadiformes, Family Macrouridae

Family Merluciidae

Order OpHIDIFormes, Family Bythitidae
71. Muraena lentiginosa Jenyns, 1842

Ref. ${ }^{1}$

72. Scuticaria tigrina (Lesson, 1828)

34,35

73. Sideria picta (Ahl, 1789)

34,35

74. Uropterygius macrocephalus (Bleeker, 1865)

34,35

75. Uropterygius versutus Bussing, 1991

$31,34,35$

76. Myroconger nigrodentatus Castle \& Béarez, 1995

34,35

77. Bascanichthys bascanoides Osborn \& Nichols, 1916

122,163

34,35

78. Callechelys eristigma McCosker \& Rosenblatt, 1972

79. Gordiichthys combibus McCosker \& Lavenberg, 2001

$34,35,121$

34,35

34,35

34,35

81. Ichthyapus selachops (Jordan \& Gilbert, 1882)

$34,35,163$

Myrichthys tigrinus Girard, 1859

34,35

83. Myrichthys aspetocheiros McCosker \& Rosenblatt, 1993

84. Ophichthus rugifer Jordan \& Bollman, 1890

85. Ophichthus triserialis (Kaup, 1856)

$34,35,122$

142

122

86. Paraletharchus opercularis (Myers \& Wade, 1941)

34,35

87. Paraletharchus pacificus (Osburn \& Nichols, 1916)

88. Quassiremus evionthas (Jordan \& Bollman, 1889)

89. Scytalichthys miurus (Jordan \& Gilbert, 1882)

90. Guentherus altivela Osório, 1917

91. Aulopus bajacali Parin \& Kotlyar, 1984

92. Chlorophthalmus mento Garman, 1899

93. Synodus lacertinus Gilbert, 1890

94. Anchoa ischana (Jordan \& Gilbert, 1882)

95. Elops affinis Regan, 1909

96. Chanos chanos (Forsskål, 1775)

97. Arcos poecilophthalmos (Jenyns, 1842)

98. Arcos rhodospilus (Günther, 1864)

99. Gobiesox adustus Jordan \& Gilbert, 1882

*100. Gobiesox woodsi (Schultz, 1944)

101. Tomicodon chilensis Brisout de Barneville, 1846

102. Tomicodon petersii (Garman, 1875)

*103. Tomicodon vermiculatus Briggs, 1955

104. Antennarius avalonis Jordan \& Starks, 1907

105. Antennarius coccineus (Lesson, 1831)

106. Antennarius commerson (Latreille, 1804) as A. commersoni

107. Antennarius sanguineus Gill, 1863

108. Antennatus strigatus (Gill, 1863)

109. Lophiodes caulinaris (Garman, 1899)

110. Lophiodes spilurus (Garman, 1899)

111. Dibranchus erinaceus (Garman, 1899)

*112. Ogcocephalus porrectus Garman, 1899

113. Zalieutes elater (Jordan \& Gilbert, 1882)

114. Caelorinchus canus (Garman, 1899)

115. Mataeocephalus tenuicaudus (Garman, 1899)

116. Merluccius angustimanus Garman, 1899

*117. Ogilbia cocoensis Møller, Schwarzhans \& Nielsen, 2005
$34,35,122$

34

47,163

35

35,163

35

142

142

34,35

122

34, 35

142

24, 34, 35

122

142

24, 34, 35

34,35

34,35

34,35

35

142

34,35

47, 142, 163

122

19, 34, 35,

35,47

105

105

35

35,127 


\begin{tabular}{|c|c|c|}
\hline & Species & Ref. $^{1}$ \\
\hline \multirow[t]{3}{*}{ Family Carapidae } & 118. Carapus dubius (Putnam 1874) as Encheliophis dubius & 35 \\
\hline & 119. Encheliophis vermicularis Müller, 1842 & $34,35,143$ \\
\hline & 120. Echiodon exsilium Rosenblatt, 1961 & 34,35 \\
\hline \multirow[t]{3}{*}{ Family Ophidiidae } & 121. Brotula ordwayi Hildebrand \& Barton, 1949 & 163 \\
\hline & $\begin{array}{l}\text { 122. Otophidium indefatigabile Jordan \& Bollman, } 1890 \text { as } \\
\text { O. indefatigable }\end{array}$ & 34,35 \\
\hline & 123. Petrotyx hopkinsi Heller \& Snodgrass, 1903 & 34,35 \\
\hline \multirow[t]{6}{*}{ Order Beloniformes, Family Belonidae } & 124. Ablennes hians (Valenciennes, 1846) & 142 \\
\hline & 125. Platybelone argalus pterura (Osburn \& Nichols, 1916) & 34,35 \\
\hline & 126. Strongylura exilis (Girard, 1854) & 34,35 \\
\hline & 127. Tylosurus acus melanotus (Bleeker, 1850) & 142 \\
\hline & 128. Tylosurus acus pacificus (Steindachner, 1876) & 34,35 \\
\hline & 129. Tylosurus crocodilus fodiator Jordan \& Gilbert, 1882 & 34,35 \\
\hline \multirow[t]{11}{*}{ Family Exocoetidae } & 130. Cheilopogon furcatus (Mitchill, 1815) & 143 \\
\hline & 131. Cheilopogon spilonotopterus (Bleeker, 1865) & 143 \\
\hline & 132. Cheilopogon xenopterus (Gilbert, 1890) & 142 \\
\hline & 133. Exocoetus monocirrhus Richardson, 1846 & 34,35 \\
\hline & 134. Exocoetus volitans Linnaeus, 1758 & 34,35 \\
\hline & 135. Hirundichthys marginatus (Nichols \& Breder, 1928) & 142 \\
\hline & 136. Hirundichthys rondeletii (Valenciennes, 1847) & 142 \\
\hline & 137. Hirundichthys speculiger (Valenciennes, 1847) & 34,35 \\
\hline & $\begin{array}{l}\text { 138. Oxyporhamphus micropterus } \\
\text { (Cuvier \& Valenciennes, 1847) }\end{array}$ & 84 \\
\hline & 139. Prognichthys sealei Abe, 1955 & 34 \\
\hline & 140. Prognichthys tringa Breder, 1928 & 34,35 \\
\hline \multirow[t]{3}{*}{ Family Hemiramphidae } & 141. Euleptorhamphus viridis (Van Hasselt, 1823) & 34,35 \\
\hline & 142. Hemiramphus saltator Gilbert \& Starks, 1904 & 142 \\
\hline & 143. Hyporhamphus rosae (Jordan \& Gilbert, 1880) & 142 \\
\hline \multirow[t]{2}{*}{ Order ATHERINIFORMES, Family Atherinopsidae } & 144. Atherinella eriarcha (Jordan \& Gilbert, 1881) & 34,35 \\
\hline & 145. Melanorhinus cyanellus (Meek \& Hildebrand, 1923) & 34,35 \\
\hline \multirow[t]{4}{*}{ Order Beryciformes, Family Holocentridae } & 146. Myripristis berndti Jordan \& Evermann, 1903 & 34,35 \\
\hline & 147. Myripristis leiognathus Valenciennes, 1846 & 34,35 \\
\hline & 148. Plectrypops lima (Valenciennes, 1831) & 34,35 \\
\hline & 149. Sargocentron suborbitalis (Gill, 1863) & 34,35 \\
\hline Order Gasterosteiformes, Family Aulostomidae & 150. Aulostomus chinensis (Linnaeus, 1766) & 35 \\
\hline Family Fistulariidae & 151. Fistularia commersonii Rüppell, 1838 & 35 \\
\hline \multirow[t]{4}{*}{ Family Syngnathidae } & 152. Bryx veleronis Herald, 1940 & 34,35 \\
\hline & 153. Cosmocampus arctus (Jenkins \& Evermann, 1889) & 142 \\
\hline & 154. Doryrhamphus excisus Kaup, 1856 & 34,35 \\
\hline & 155. Hippocampus ingens Girard, 1858 & 34,35 \\
\hline \multirow[t]{2}{*}{ Order SCORPAENIFORMES, Family Peristediidae } & 156. Peristedion crustosum Garman, 1899 & 34,35 \\
\hline & *157. Peristedion nesium Bussing, 2010 & 33 \\
\hline \multirow[t]{7}{*}{ Family Scorpaenidae } & 158. Pontinus clemensi Fitch, 1955 & 34,35 \\
\hline & 159. Pontinus sierra Gilbert, 1890 & 34,35 \\
\hline & 160. Pontinus strigatus Heller \& Snodgrass, 1903 & $34,35,122$ \\
\hline & 161. Pontinus furcirhinus Garman, 1899 & 142 \\
\hline & 162. Scorpaena afuerae Hildebrand, 1946 & 34,35 \\
\hline & 163. Scorpaena cocosensis Motomura, 2004 & 122,132 \\
\hline & 164. Scorpaena histrio Jenyns, 1840 & 34,35 \\
\hline
\end{tabular}




\begin{tabular}{|c|c|c|}
\hline & Species & Ref. $^{1}$ \\
\hline & 165. Scorpaena mystes Jordan \& Starks en Jordan, 1895 & 34,35 \\
\hline & 166. Scorpaena russula Jordan \& Bollman, 1890 & 34,35 \\
\hline & 167. Scorpaena new species & 34,35 \\
\hline & $\begin{array}{l}\text { 168. Scorpaenodes rubrivinctus Poss, McCosker \& } \\
\text { Baldwin } 2010\end{array}$ & $\begin{array}{l}122,138 \\
163\end{array}$ \\
\hline & 169. Scorpaenodes xyris (Jordan \& Gilbert, 1882) & 34,35 \\
\hline \multirow[t]{3}{*}{ Family Triglidae } & 170. Bellator loxias (Jordan, 1897) & $34,35,163$ \\
\hline & 171. Bellator new species & 34,35 \\
\hline & 172. Prionotus new species & 34,35 \\
\hline \multirow[t]{7}{*}{ Order Perciformes, Family Acanthuridae } & 173. Acanthurus nigricans (Linnaeus, 1758) & 34,35 \\
\hline & 174. Acanthurus triostegus Linnaeus, 1758 & 34,35 \\
\hline & 175. Acanthurus xanthopterus Valenciennes, 1835 & 34,35 \\
\hline & 176. Ctenochaetus marginatus (Valenciennes, 1835) & 34,35 \\
\hline & 177. Naso annulatus (Quoy \& Gaimard, 1825) & 142 \\
\hline & 178. Naso hexacanthus (Bleeker, 1855) & 142 \\
\hline & 179. Prionurus laticlavius (Valenciennes, 1846) & 34,35 \\
\hline \multirow[t]{2}{*}{ Family Apogonidae } & 180. Apogon atradorsatus Heller \& Snodgrass, 1903 & $34,35,122$ \\
\hline & 181. Apogon dovii Günther, 1861 & 34,35 \\
\hline \multirow[t]{4}{*}{ Family Blenniidae } & 182. Entomacrodus chiostictus (Jordan \& Gilbert, 1882) & 34,35 \\
\hline & 183. Hypsoblennius brevipinnis (Günther, 1861) & 34,35 \\
\hline & 184. Ophioblennius steindachneri Jordan \& Evermann, 1898 & 34,35 \\
\hline & 185. Plagiotremus azaleus (Jordan \& Bollman, 1890) & 34,35 \\
\hline Family Bramidae & 186. Brama dussumieri Cuvier, 1831 & 142 \\
\hline Family Callionymidae & 187. Synchiropus atrilabiatus (Garman, 1899) & 35 \\
\hline \multirow[t]{19}{*}{ Family Carangidae } & 188. Alectis ciliaris (Bloch, 1787) & 34,35 \\
\hline & 189. Carangoides orthogrammus Jordan \& Gilbert, 1882 & 34,35 \\
\hline & 190. Caranx caballus (Günther, 1868) & 34,35 \\
\hline & 191. Caranx caninus Günther, 1867 & 34,35 \\
\hline & 192. Caranx lugubris Poey, 1860 & 34,35 \\
\hline & 193. Caranx melampygus Cuvier, 1833 & 34,35 \\
\hline & 194. Caranx sexfasciatus Quoy \& Gaimard, 1825 & 34,35 \\
\hline & 195. Decapterus macarellus (Cuvier, 1833) & 34,35 \\
\hline & 196. Elagatis bipinnulata (Quoy \& Gaimard, 1825) & 34,35 \\
\hline & 197. Gnathanodon speciosus (Forsskål, 1775) & 34,35 \\
\hline & 198. Naucrates ductor (Linnaeus, 1758) & 34,35 \\
\hline & 199. Selar crumenophthalmus (Bloch, 1793) & 34,35 \\
\hline & 200. Seriola lalandi Valenciennes, 1833 & 34,35 \\
\hline & 201. Seriola peruana Steindachner, 1881 & 34,35 \\
\hline & 202. Seriola rivoliana Valencienne, 1833 & 34,35 \\
\hline & 203. Trachinotus rhodopus Gill, 1863 & 142 \\
\hline & 204. Trachinotus stilbe (Jordan \& McGregor, 1898) & 34,35 \\
\hline & 205. Trachurus murphyi Nichols, 1920 & 122 \\
\hline & 206. Uraspis helvola (Forster, 1801) & 34,35 \\
\hline Family Centrolophidae & 207. Seriolella violacea Guichenot, 1848 & 122 \\
\hline \multirow[t]{5}{*}{ Family Chaenopsidae } & *208. Acanthemblemaria atrata Hastings \& Robertson, 1999 & $34,35,95$ \\
\hline & 209. Acanthemblemaria macrospilus Brock, 1940 & 151 \\
\hline & 210. Chaenopsis new species & 34,35 \\
\hline & 211. Coralliozetus boehlkei Stephens, 1963 & 34,35 \\
\hline & 212. Coralliozetus springeri Stephens \& Johnson, 1966 & 34,35 \\
\hline
\end{tabular}




\begin{tabular}{|c|c|c|}
\hline & Species & Ref. $^{1}$ \\
\hline & 213. Ekemblemaria myersi Stephens, 1963 & 142 \\
\hline & 214. Emblemaria nivipes Jordan \& Gilbert, 1883 & $34,35,160$ \\
\hline & 215. Stathmonotus culebrai Seale, 1940 & 142 \\
\hline \multirow[t]{6}{*}{ Family Chaetodontidae } & 216. Chaetodon humeralis Günther, 1860 & 34,35 \\
\hline & 217. Chaetodon lunula (Lacepède, 1802) & 34,35 \\
\hline & 218. Forcipiger flavissimus Jordan \& McGregor, 1898 & 34,35 \\
\hline & 219. Johnrandallia nigrirostris (Gill, 1862) & 34,35 \\
\hline & 220. Prognathodes carlhubbsi Nalbant, 1995 & 142 \\
\hline & 221. Prognathodes falcifer (Hubbs \& Rechnitzer, 1958) & 34,35 \\
\hline \multirow[t]{2}{*}{ Family Cirrhitidae } & 222. Cirrhitichthys oxycephalus (Bleeker, 1855) & $34,35,160$ \\
\hline & 223. Cirrhitus rivulatus Valenciennes, 1846 & 34,35 \\
\hline \multirow[t]{5}{*}{ Family Coryphaenidae } & 224. Coryphaenoides anguliceps (Garman, 1899) & 104 \\
\hline & 225. Coryphaenoides boops (Garman, 1899) & 104 \\
\hline & 226. Coryphaenoides bucephalus (Garman, 1899) & 104 \\
\hline & 227. Coryphaena equiselis Linnaeus, 1758 & 34,35 \\
\hline & 228. Coryphaena hippurus Linnaeus, 1758 & 34,35 \\
\hline \multirow[t]{3}{*}{ Family Dactyloscopidae } & 229. Dactyloscopus lacteus (Myers \& Wade, 1946) & 142 \\
\hline & 230. Dactyloscopus pectoralis fallax Gill, 1861 & 34,35 \\
\hline & *231. Gillellus chathamensis Dawson, 1977 & $34,35,62$ \\
\hline \multirow[t]{7}{*}{ Family Echeneidae } & 232. Echeneis naucrates Linnaeus, 1758 & 142 \\
\hline & 233. Phtheirichthys lineatus (Menzies, 1791) & 142 \\
\hline & 234. Remorina albescens (Temminck \& Schlegel, 1850) & 34,35 \\
\hline & 235. Remora australis (Bennett, 1840) & 142 \\
\hline & 236. Remora brachyptera (Lowe, 1839) & 34,35 \\
\hline & 237. Remora osteochir (Cuvier, 1829) & 34,35 \\
\hline & 238. Remora remora (Linnaeus, 1758 ) & $34,35,163$ \\
\hline \multirow[t]{2}{*}{ Family Eleotridae } & 239. Eleotris picta Kner, 1863 & 34,35 \\
\hline & 240. Gobiomorus maculatus (Günther, 1859) & 142 \\
\hline \multirow[t]{3}{*}{ Family Gempylidae } & 241. Gempylus serpens Cuvier, 1829 & 142 \\
\hline & 242. Lepidocybium flavobrunneum (Smith, 1843) & 142 \\
\hline & 243. Nealotus tripes Johnson, 1865 & 142 \\
\hline Family Gerreidae & 244. Eucinostomus currani Zahuranec, 1980 & 35 \\
\hline \multirow[t]{12}{*}{ Family Gobiidae } & 245. Bathygobius ramosus Ginsburg, 1947 & 34,35 \\
\hline & *246. Chriolepis atrimelum Bussing, 1997 & $32,34,35$ \\
\hline & *247. Chriolepis dialepta Bussing, 1990 & 29,34 \\
\hline & 248. Coryphopterus urospilus Ginsburg, 1938 & 34,35 \\
\hline & 249. Elacatinus nesiotes Bussing, 1990 & 29,34 \\
\hline & 250. Gobulus crescentalis (Gilbert, 1892) & 142 \\
\hline & 251. Gobulus hancocki Ginsburg, 1938 & 34,35 \\
\hline & *252. Lythrypnus alphigena Bussing, 1990 & 29,34 \\
\hline & *253. Lythrypnus cobalus Bussing, 1990 & 29,34 \\
\hline & *254. Lythrypnus lavenbergi Bussing, 1990 & 29,34 \\
\hline & 255. Lythrypnus rhizophora (Heller \& Snodgrass, 1903) & $34,35,122$ \\
\hline & *256. Sicydium cocoensis (Heller \& Snodgrass, 1903) & 34,35 \\
\hline \multirow[t]{3}{*}{ Family Haemulidae } & 257. Anisotremus caesius (Jordan \& Gilbert, 1882) & 34,35 \\
\hline & 258. Anisotremus interruptus (Gill, 1862) & 34,35 \\
\hline & 259. Anisotremus taeniatus Gill, 1861 & 34,35 \\
\hline Family Istiophoridae & 260. Istiompax indica (Cuvier, 1832) & 142 \\
\hline Family Kuhliidae & 261. Kuhlia mugil (Forster, 1801) & 35 \\
\hline
\end{tabular}




\begin{tabular}{|c|c|c|}
\hline & Species & Ref. $^{1}$ \\
\hline \multirow[t]{3}{*}{ Family Kyphosidae } & 262. Kyphosus analogus (Gill, 1862) & 142 \\
\hline & 263. Kyphosus elegans (Peters, 1869) & 34,35 \\
\hline & 264. Sectator ocyurus (Jordan \& Gilbert, 1882) & 34,35 \\
\hline \multirow[t]{17}{*}{ Family Labridae } & 265. Bodianus diplotaenia (Gill, 1862) & 34,35 \\
\hline & 266. Decodon melasma Gomon, 1974 & $\begin{array}{c}28,34,35 \\
163\end{array}$ \\
\hline & $\begin{array}{l}\text { 267. Halichoeres adustus (Gilbert, 1890) as } \\
\text { Pseudojulis adustus }\end{array}$ & $\begin{array}{c}28,34,35 \\
122\end{array}$ \\
\hline & 268. Halichoeres discolor Bussing, 1983 & $27,34,35$ \\
\hline & 269. Halichoeres dispilus (Günther, 1864) & 34,35 \\
\hline & 270. Halichoeres nicholsi (Jordan \& Gilbert, 1882) & 34,35 \\
\hline & 271. Halichoeres notospilus (Günther, 1864) & 142 \\
\hline & 272. Halichoeres raisneri Baldwin \& McCosker, 2001 & 97 \\
\hline & *273. Halichoeres salmofasciatus Allen \& Robertson, 2002 & 4 \\
\hline & 274. Iniistius pavo (Valenciennes, 1840) & 34,35 \\
\hline & 275. Novaculichthys taeniourus (Lacepède, 1801) & 34,35 \\
\hline & 276. Polylepion cruentum Gomon, 1977 & 34,35 \\
\hline & 277. Stethojulis bandanensis (Bleeker, 1851) & 34,35 \\
\hline & 278. Thalassoma grammaticum Gilbert, 1890 & 34,35 \\
\hline & 279. Thalassoma lucasanum (Gill, 1862) & 34,35 \\
\hline & 280. Thalassoma purpureum (Forsskål, 1775) & 34 \\
\hline & 281. Xyrichtys victori Wellington, 1992 as Xyrichthys victori & $34,35,122$ \\
\hline \multirow[t]{3}{*}{ Family Labrisomidae } & 282. Dialommus fuscus (Gilbert, 1891) & 122,123 \\
\hline & 283. Paraclinus mexicanus (Gilbert, 1904) & 34,35 \\
\hline & 284. Starksia new species & 34,35 \\
\hline \multirow[t]{10}{*}{ Family Lutjanidae } & 285. Aphareus furca (Lacepède, 1801) & 34,35 \\
\hline & 286. Hoplopagrus guentherii Gill, 1862 as H. guntheri & 34,35 \\
\hline & 287. Lutjanus aratus (Günther, 1864) & 34,35 \\
\hline & 288. Lutjanus argentiventris (Peters, 1869) & 34,35 \\
\hline & 289. Lutjanus colorado Jordan \& Gilbert, 1882 & 142 \\
\hline & 290. Lutjanus guttatus (Steindachner, 1869) & 142 \\
\hline & 291. Lutjanus inermis (Peters, 1869) & 34,35 \\
\hline & 292. Lutjanus jordani (Gilbert, 1898) & 34,35 \\
\hline & 293. Lutjanus novemfasciatus Gill, 1862 & 34,35 \\
\hline & 294. Lutjanus viridis (Valenciennes, 1846) & 34,35 \\
\hline Family Luvaridae & 295. Luvarus imperialis Rafinesque, 1810 & 142 \\
\hline \multirow[t]{4}{*}{ Family Malacanthidae } & 296. Caulolatilus affinis Gill, 1865 & 34,35 \\
\hline & 297. Caulolatilus hubbsi Dooley, 1978 & 34,35 \\
\hline & 298. Caulolatilus princeps (Jenyns, 1840) & 142 \\
\hline & 299. Malacanthus brevirostris Guichenot, 1848 & 34,35 \\
\hline Family Microdesmidae & 300. Clarkichthys bilineatus (Clark, 1936) & 35 \\
\hline \multirow[t]{4}{*}{ Family Mugilidae } & 301. Agonostomus monticola (Brancroft, 1834) & 34,35 \\
\hline & $\begin{array}{l}\text { 302. Chaenomugil proboscideus (Günther, 1861) as } \\
\text { C. proboscidens }\end{array}$ & 34,35 \\
\hline & 303. Mugil cephalus Linnaeus, 1758 & 142 \\
\hline & 304. Mugil curema Valenciennes, 1836 & 34,35 \\
\hline Family Mullidae & 305. Mulloidichthys dentatus (Gill, 1862) & 35 \\
\hline \multirow[t]{2}{*}{ Family Nomeidae } & 306. Cubiceps pauciradiatus Günther, 1872 & 142 \\
\hline & 307. Nomeus gronovii (Gmelin, 1789) & 142 \\
\hline
\end{tabular}




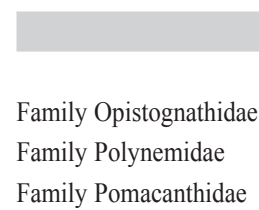

Family Priacanthidae

Family Scaridae

Family Sciaenidae

Family Scombridae

Family Serranidae

\section{Species}

308. Psenes cyanophrys Valenciennes, 1833

309. Opistognathus panamaensis Allen \& Robertson, 1991

142

310. Polydactylus approximans (Lay \& Bennett, 1839)

311. Holacanthus passer Valenciennes, 1846 34,35

312. Pomacanthus zonipectus (Gill, 1862) 34,35

313. Abudefduf concolor (Gill, 1862)

34,35

314. Abudefduf troschelii (Gill, 1862) as A. troshelli

34,35

315. Chromis alta Greenfield \& Woods, 1980

34,35

316. Chromis atrilobata Gill, 1862

34,35

317. Microspathodon bairdii (Gill, 1862)

318. Microspathodon dorsalis (Gill, 1862)

319. Stegastes acapulcoensis (Fowler, 1944)

34,35

34,35

34,35

320. Stegastes arcifrons (Heller \& Snodgrass, 1903)

34,35

321. Stegastes beebei (Nichols, 1924)

322. Stegastes flavilatus (Gill, 1862)

$34,35,122$

34,35

323. Cookeolus japonicus (Cuvier, 1829)

324. Heteropriacanthus cruentatus (Lacepède, 1801)

325. Pristigenys serrula (Gilbert, 1891)

$34,35,47$

34,35

142

35

142

327. Corvula macrops (Steindachner, 1876)

142

328. Odontoscion eurymesops (Heller \& Snodgrass, 1903)

329. Umbrina galapagorum Steindachner, 1878

330. Umbrina xanti Gill, 1862

331. Acanthocybium solandri (Cuvier, 1832)

34,35

332. Auxis rochei (Risso, 1810)

34,35

333. Auxis thazard (Lacepède, 1800)

34,35

334. Euthynnus lineatus Kishinouye, 1920

34,35

335. Katsuwonus pelamis (Linnaeus, 1758)

34,35

336. Sarda orientalis (Temminck \& Schlegel, 1844)

34,35

337. Scomber japonicus Houttuyn, 1782

142

338. Scomberomorus sierra Jordan \& Starks, 1895

34,35

339. Thunnus albacares (Bonnaterre, 1788)

34,35

340. Thunnus obesus (Lowe, 1839)

142

34,35

Retall2

342. Anthias noeli Anderson \& Baldwin, 2000

34,35

343. Cephalopholis panamensis (Steindachner, 1877)

344. Cratinus agassizii Steindachner, 1878

122

34,35

345. Dermatolepis dermatolepis (Boulenger, 1895)

$34,35,47$, 163

347. Epinephelus itajara (Lichtenstein, 1822)

34,35

34,35

348. Epinephelus labriformis (Jenyns, 1840)

$34,35,163$

142

97

351. Liopropoma longilepis Garman, 1899

$34,35,122$, 163

34,35

353. Paranthias colonus (Valenciennes, 1846)

34,35 


\begin{tabular}{|c|c|c|}
\hline & Species & Ref. $^{1}$ \\
\hline & 355. Pronotogrammus multifasciatus Gill, 1863 & $\begin{array}{l}34,35,47 \\
163\end{array}$ \\
\hline & 356. Pseudogramma thaumasium (Gilbert, 1900) & 34,35 \\
\hline & 357. Serranus aequidens Gilbert, 1890 & 34,35 \\
\hline & $\begin{array}{l}\text { 358. Serranus tico Meisler \& Lavenberg in Allen \& } \\
\text { Robertson, } 1998\end{array}$ & $34,35,126$ \\
\hline & 359. Rypticus bicolor Valenciennes, 1846 & 34,35 \\
\hline Family Sphyraenidae & 360. Sphyraena idiastes Heller \& Snodgrass, 1903 & 35 \\
\hline Family Tripterygiidae & *361. Axoclinus cocoensis Bussing, 1991 & 30,35 \\
\hline \multirow[t]{6}{*}{ Family Xiphiidae } & 362. Istiophorus platypterus (Shaw in Shaw \& Nodder, 1792) & 34,35 \\
\hline & 363. Makaira indica (Cuvier, 1832) & 34 \\
\hline & 364. Makaira mazara (Jordan \& Snyder, 1901) & 34,35 \\
\hline & 365. Tetrapturus angustirostris Tanaka, 1915 & 34 \\
\hline & 366. Tetrapturus audax (Philippi, 1887) & 34,35 \\
\hline & 367. Xiphius gladius Linnaeus, 1758 & 34 \\
\hline Family Zanclidae & 368. Zanclus cornutus (Linnaeus, 1758) & 34 \\
\hline \multirow[t]{2}{*}{ Order Pleuronectiformes, Family Bothidae } & 369. Bothus leopardinus (Günther, 1862) & 34,35 \\
\hline & 370. Bothus mancus (Broussonet, 1782) & 34,35 \\
\hline \multirow[t]{3}{*}{ Family Cynoglossidae } & 371. Symphurus atramentatus Jordan \& Bollman, 1890 & 142 \\
\hline & 372. Symphurus oligomerus Mahadeva \& Munroe, 1990 & 142 \\
\hline & 373. Symphurus varius Garman, 1899 & 35 \\
\hline \multirow[t]{4}{*}{ Family Paralichthyidae } & 374. Citharichthys platophrys Gilbert, 1891 & 142 \\
\hline & 375. Hippoglossina bollmani Gilbert, 1890 & 34,35 \\
\hline & 376. Syacium latifrons (Jordan \& Gilbert, 1882) & 34,35 \\
\hline & *377. Syacium maculiferum (Garmann, 1899) & $34,35,142$ \\
\hline Family Soleidae & 378. Aseraggodes herrei Seale, 1940 & 35 \\
\hline \multirow[t]{8}{*}{ Order Tetraodontiformes, Family Balistidae } & 379. Balistes polylepis Steindachner, 1876 & 34,35 \\
\hline & 380. Canthidermis maculata (Bloch, 1786) as C. maculatus & 34,35 \\
\hline & 381. Melichthys niger (Bloch, 1786) & 34,35 \\
\hline & 382. Melichthys vidua (Richardson, 1845) & 34,35 \\
\hline & 383. Pseudobalistes naufragium (Jordan \& Starks, 1895) & 34,35 \\
\hline & 384. Sufflamen verres (Gilbert \& Starks, 1904) & 34,35 \\
\hline & $\begin{array}{l}\text { 385. Xanthichthys caeruleolineatus Randall, Matsuura \& } \\
\text { Zama, } 1978\end{array}$ & $34,35,84$ \\
\hline & 386. Xanthichthys mento (Jordan \& Gilbert, 1882) & 34,35 \\
\hline \multirow[t]{4}{*}{ Family Diodontidae } & $\begin{array}{l}\text { 387. Chilomycterus reticulatus (Linnaeus, 1758) as } \\
\text { C. reticulotus }\end{array}$ & 34,35 \\
\hline & 388. Diodon eydouxii Brisout de Barneville, 1846 & 142 \\
\hline & 389. Diodon holocanthus Linnaeus, 1758 & 34,35 \\
\hline & 390. Diodon hystrix Linnaeus, 1758 & 34,35 \\
\hline \multirow[t]{2}{*}{ Family Molidae } & 391. Mola mola (Linnaeus, 1758) & 143 \\
\hline & 392. Ranzania laevis (Pennant, 1776) & 143 \\
\hline \multirow[t]{3}{*}{ Family Monacanthidae } & 393. Aluterus monocerus (Linnaeus, 1758) & 34,35 \\
\hline & 394. Aluterus scriptus (Osbeck, 1765) & 34,35 \\
\hline & 395. Cantherhines dumerilii (Hollard, 1854) & 34,35 \\
\hline Family Ostraciidae & 396. Ostracion meleagris Shaw, 1796 & 35 \\
\hline \multirow[t]{3}{*}{ Family Tetraodontidae } & 397. Arothron hispidus (Linnaeus, 1758) & 34,35 \\
\hline & 398. Arothron meleagris (Lacepède, 1798) & 34,35 \\
\hline & 399. Canthigaster punctatissima (Günther, 1870) & 34,35 \\
\hline
\end{tabular}




\author{
Class REPTILIA, Order Testudinata \\ Family Cheloniidae \\ Family Dermochelyidae \\ Order Souamata, Family Elapidae \\ Class AVES, Order Procellarifformes, \\ Family Diomedeidae \\ Family Hydrobatidae \\ Family Procellariidae \\ Order Pelecaniformes, Family Fregatidae \\ Family Pelecanidae \\ Family Phaethontidae \\ Family Sulidae
}

Order CharadriIFormes, Family Charadriidae

Family Laridae

Family Phalaropodidae

Family Scolopacidae

400. Lagocephalus lagocephalus (Linnaeus, 1758)

403. Lepidochelys olivacea (Eschscholtz, 1829)

84

404. Eretmochelys imbricata (Linné, 1766)

84

405. Chelonia agassizi Bocourt, 1868

406. Dermochelys coriacea (Vandelli, 1761)

407. Pelamis platurus (Linné, 1766)

408. Phoebastria irrorata (Salvin, 1883)

409. Oceanodroma castro (Harcourt, 1851)

12,128

410. Oceanodroma leucorhoa (Vieillot, 1818)

12,128

411. Oceanodroma markhami (Salvin, 1883)

12,128

412. Oceanodroma melania (Bonaparte, 1854)

12,128

413. Oceanodroma tethys (Bonaparte, 1852)

12,128

414. Pelagodroma marina (Latham, 1790)

12,128

415. Pterodroma phaeopygia (Salvin, 1876)

12,128

416. Puffinus creatopus Coues, 1864

12,128

417. Puffinus lherminieri Lesson, 1839

12,128

418. Puffinus pacificus (J.F. Gmelin, 1789)

12,128

419. Fregata magnificens Mathews, 1914

12,128

420. Fregata minor (J.F. Gmelin, 1789)

12,128

421. Pelecanus occidentales Linnaeus, 1766

422. Phaethon lepturus Daudin, 1802

423. Sula dactylatra Lesson, 1831

12,128

424. Sula leucogaster (Boddaert, 1783)

12,128

425. Sula nebouxii Milne-Edwards, 1882

12,128

426. Sula sula (Linnaeus, 1766)

12,128

427. Charadrius semipalmatus Bonaparte, 1825

428. Charadrius wilsonia Ord, 1814

429. Pluvialis dominica (Statius Müller, 1776)

430. Pluvialis squatarola (Linnaeus, 1758)

431. Anous minutus Boie, 1844

432. Anous stolidus (Linnaeus, 1758)

12,128

433. Creagrus furcatus (Neboux, 1846)

$12,128,187$

434. Gygis alba (Sparrman, 1786)

12,128

435. Larus argentatus Pontoppidan, 1763

12,128

436. Larus atricilla Linnaeus, 1758

12,128

437. Larus modestus Tschudi, 1843

12,128

438. Larus pipixcan Wagler, 1831

12,128

439. Onychoprion fuscatus Linnaeus, 1766

12,128

440. Thalasseus elegans (Gambel, 1849)

12,128

441. Thalasseus sandvicensis Latham, 1787

12,128

442. Xema sabini (Sabine, 1819)

12,128

443. Phalaropus fulicarius (Linnaeus, 1758)

444. ? Steganopus tricolor (Vieillot, 1819)

445. Actitis macularia (Linnaeus, 1766)

446. Arenaria interpres (Linnaeus, 1758) 


\begin{tabular}{|c|c|c|}
\hline & Species & Ref. $^{1}$ \\
\hline & 447. Calidris alba (Pallas, 1764) & 12 \\
\hline & 448. Calidris bairdii (Coues, 1861) & 12 \\
\hline & 449. Calidris fuscicollis (Vieillot, 1819) & 12 \\
\hline & 450. Calidris himantopus (Bonaparte, 1826) & 12 \\
\hline & 451. Calidris mauri (Cabanis, 1857) & 12 \\
\hline & 452. Calidris melanotos (Vieillot, 1819) & 12 \\
\hline & 453. Calidris minutilla (Vieillot, 1819) & 12 \\
\hline & 454. Calidris pusilla (Linnaeus, 1766) & 12 \\
\hline & 455. Catoptrophorus semipalmatus (J.F. Gmelin, 1789) & 12 \\
\hline & 456. Heteroscelus incanus (J.F. Gmelin, 1789) & 12 \\
\hline & 457. Numenius phaeopus (Linnaeus, 1758) & 12 \\
\hline & 458. Tringa flavipes (J.F. Gmelin, 1789) & 12 \\
\hline & 459. Tringa melanoleuca (J.F. Gmelin, 1789) & 12 \\
\hline & 460. Tringa solitaria A. Wilson, 1813 & 12 \\
\hline \multirow[t]{2}{*}{ Family Stercorariidae } & 461. Stercorarius parasiticus (Linnaeus, 1758) & 12,128 \\
\hline & 462. Stercorarius pomarinus (Temminck, 1815) & 12,128 \\
\hline \multicolumn{3}{|l|}{ Class MAMMALIA, Order CARNIVORA } \\
\hline \multirow[t]{2}{*}{ Suborder PINNIPEDIA, Family Otariidae } & 463. Zalophus californianus Lesson, 1828 & 120,129 \\
\hline & 464. Zalophus wollebaeki Sivertsen, 1953 & 120,129 \\
\hline \multirow[t]{4}{*}{$\begin{array}{l}\text { Order CETACEA, Suboren Mysticeti, } \\
\text { Family Balaenopteridae }\end{array}$} & 465. Balaenoptera borealis Lesson, 1828 & 120 \\
\hline & 466. Balaenoptera edeni Anderson, 1878 & 120 \\
\hline & 467. Balaenoptera physalus, Linnaeus, 1758 & 120 \\
\hline & 468. Megaptera novaeangliae Borowski, 1781 & 120 \\
\hline \multirow[t]{6}{*}{ Suborder Odontocetı, Family Delphinidae } & 469. Globicephala macrorhynchus Gray, 1846 & 120 \\
\hline & 470. Grampus griseus Cuvier, 1812 & 120 \\
\hline & 471. Orcinus orca Linnaeus, 1758 & 120 \\
\hline & 472. Stenella longirostris Gray, 1828 & 120 \\
\hline & 473. Stenella coeruleoalba Meyen, 1833 & 120 \\
\hline & 474. Tursiops truncatus Montagu, 1821 & 120 \\
\hline Family Physeteridae & 475. Physeter macrocephalus Linnaeus, 1766 & 120 \\
\hline \multirow[t]{3}{*}{ Family Ziphiidae } & 476. Mesoplodon densirostris Blainville, 1817 & 120 \\
\hline & 477. Mesoplodon sp. & 120 \\
\hline & 478. Ziphius cavirostris Cuvier, 1823 & 120 \\
\hline
\end{tabular}

(1) References are indicated by numbers according to the reference list

$*=$ Endemic

Species/Genus in bold type $=$ present at Isla del Coco but not on the Pacific coast of mainland Costa Rica $?=$ doubts about the identification

(a) Reported by Hertlein (1963) but not found in any database.

(b) Species described in: Suárez-Morales, E. \& R. Gasca. 2012. A new Lepeophtheirus (Copepoda: Siphonostomatoida: Caligidae) from Isla del Coco, Costa Rica, Eastern Tropical Pacific. Rev. Biol. Trop. 60 (Suppl. 3): 235-242. 
